\title{
ESTIMATIVA DOS FLUXOS DE CALOR SENSÍVEL E CALOR LATENTE NO INTERIOR DE UMA CULTURA DE MILHO (Zea mays, L.)
}

\author{
ANGELA MARIA SOARES
}

Orientador: Afonso Decico

Dissertação apresentada à Escola Superior de Agricultura "Luiz de Queiroz", da Universidade de São Paulo, para obtenção do título de Mestre em Agrometeorologia.

PIRACICABA

Estado de São Paulo - Brasil

Junho - 1980 


\section{AGRADECIMEN TOS}

Prof. Afonso Decico

Departamento de Física e Meteorologia - ESALQ-USP

Conselho Nacional de Pesquisas

Fundação Cargil1 
INDICE

Pāgina

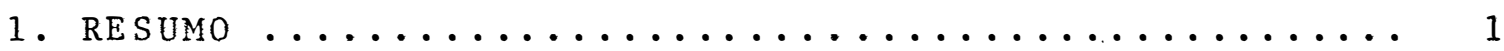

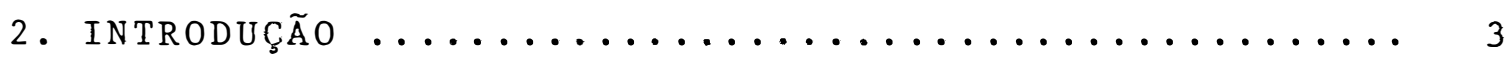

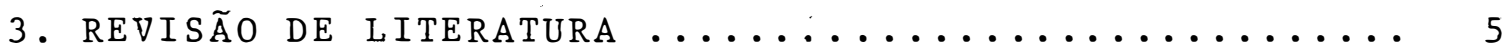

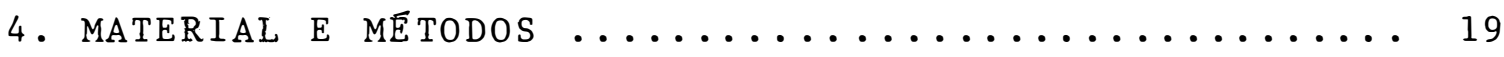

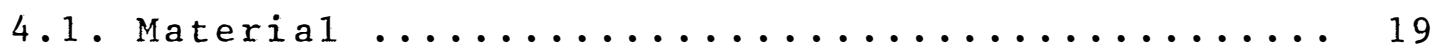

4.1.1. Caracterização das condições do experi -

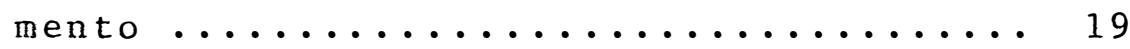

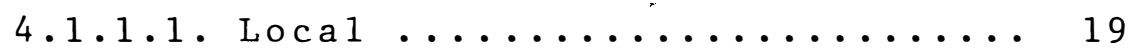

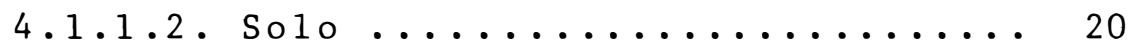

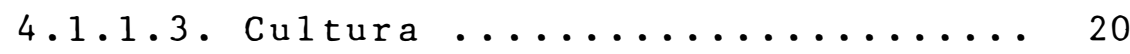

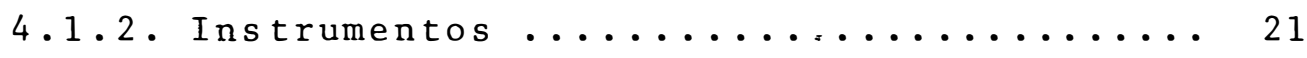

4.1 .2 .1 . Anemômetros $\ldots \ldots \ldots \ldots \ldots \ldots \ldots \ldots$

4.1 .2 .2 . Psicrômetros $\ldots \ldots \ldots \ldots \ldots \ldots \ldots$

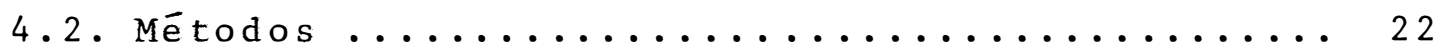

4.2.1. Métodos de determinação de $K$ no interior

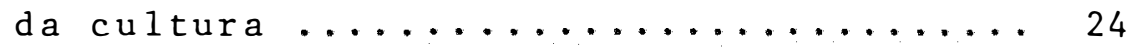

4.2.2. Método utilizado para determinação de $\mathrm{K}_{\mathrm{H}}$ e $\mathrm{K}_{\mathrm{W}}$ no interior da cultura ........... 27

4.2.3. Determinação de K(h) ............. 29

4.2.4. Determinação dos fluxos e das intensidades das fontes e sorvedouros de calor sen sível (H) e calor latente (LE) ........ 29

4.2.5. Medidas de temperatura ........... 30 
4.2.6. Medidas de velocidade do vento .......30

4.2.7. Tratamentos estudados ................ 31

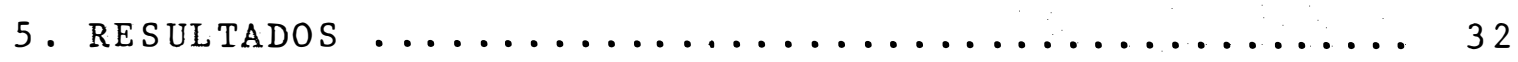

5.1. Perfis de temperatura e tensão de vapor d'água

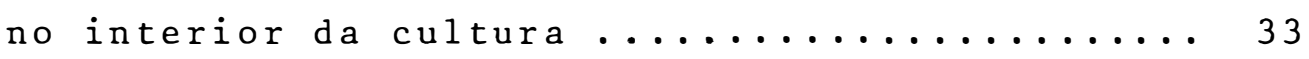

5.2. Fluxos de calor sensível e calor latente no interior da cultura ...................... 49

5.3. Distribuição vertical e as intensidades das fon tes e sorvedouros de calor sensível e calor la-

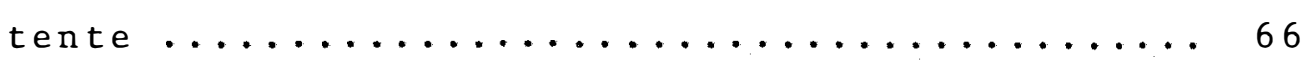

6. DISCUSST̃O dOS RESUltados ................... 71

6.1. Perfis de temperatura e tensão de vapor d'água no interior da cultura ................. 11

6.1 .1$. Perfis de temperatura ............. 71

6.1.2. Perfis de tensão de vapor d'ägua ..... 76

6.2. Fluxos de calor sensível e calor latente no interior da cultura ..................... 79

6.2 .1$. Fluxos de calor sensível .......... 80

6.2.2. Fluxos de calor latente .......... 82

6.2.3. Variação diāria dos fluxos de calor sensível e calor latente ............. 85

6.3. Distribuição vertical e as intensidades das fon tes e sorvedouros de calor sensível e calor la-

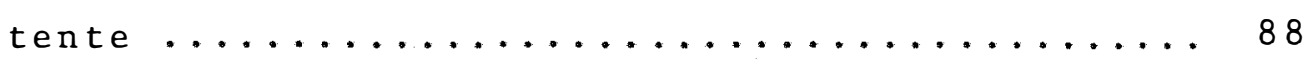

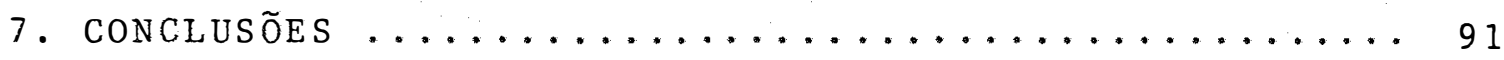




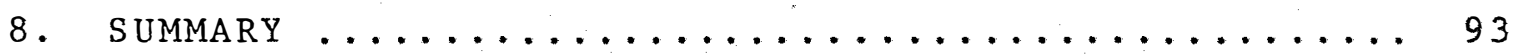

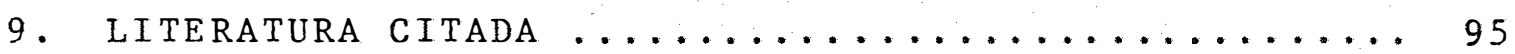


1. RESUMO

Neste trabalho procedeu-se a uma anālise quantitativa dos fluxos de calor sensível e calor latente no inte rior de uma cultura de milho (Zea mays, L.), variedade Cargil 111. Foram estudados três tratamentos diferentes durante o período diurno, permitindo assim obter informações sobre a in fluência das modificações introduzidas na técnica de plantio (orientação das plantas e espaçamento), no microclima da cultura.

Os fluxos e as intensidades das fontes e sorve douros de calor sensível e calor latente foram determinados a partir das equações fluxos-gradientes. Admitiu-se que o coeficiente de transporte $k$, no interior da cultura, varia exponencialmente com a distância à superfície do solo.

$$
\text { o tratamento } 2 \text { (plantio orientado e menor den- }
$$
sidade de plantas) apresentou uma distribuição de fontes e sor 
vedouros de calor sensível e calor latente inversa à observada nos tratamentos 1 (plantio orientado) e 3 (plantio ao acaso). As fontes e sorvedouros de calor latente mostraram - se mais vigorosas que as de calor sensivel nos três tratamentos. os fluxos mais intensos foram verificados nas proximidades do nível médio da cultura e no período médio do dia, observandose os fluxos de calor sensível e calor latente mais intensos nos tratamentos 2 e 3 , respectivamente. 
Nos $\bar{l} 1$ timos anos muitos estudos teem sido feitos visando o desenvolvimento de equipamentos e instrumentos para medida dos elementos de microclima de uma cultura. Obser va-se também um crescente interesse na formulação de modelos capazes de descrever fenômenos que ocorrem no sistema plantameio ambiente. Estes fatos contribuem para um maior conhecimento das relações planta-meio ambiente, fornecendo assim as bases necessárias para o desenvolvimento de novas técnicas, que possibilitem obter maior produtividade e melhor qualidade dos produtos agrícolas, a partir da manipulação do meio ambiente ou da adaptação de plantas a meios considerados inadequa dos.

Através do estudo das respostas das plantas ao seu microclima pode-se identificar os fatores que determinam um dado regime de temperatura, umidade ou vento. Além disso, permite identificar como estes elementos atuam no desenvolvi- 
mento e crescimento das plantas e como influenciam as taxas de transpiração e fotossintese. Assim sendo, tornam-se desneces -sários os comentários sobre a importância destes estudos.

As plantas, quando expostas à. radiação solar, absorvem energia, utilizando-a no processo fotossintético, na evaporação da água e no próprio aquecimento. Estes fenômenos implicam em trocas de diöxido de carbono, vapor d'água e calor com a atmosfera que as envolve. Tais processos de transporte ocorrem graças ao movimento turbulento e são essenciais para sobrevivência das plantas, pois na sua ausência elas poderiam atingir temperaturas elevadas, que dificilmente conseguiriam suportar. Diante destas observações nota-se a validä de dos estudos das trocas de calor, vapor d'água e dióxido de carbono para uma maior compreensão do sistema planta-meio ambiente.

Pretende-se, neste trabalho, estudar o comportamento dos fluxos de calor sensível e calor latente, junta mente com a distribuição vertical e a intensidade das fontes e sorvedouros a partir de dados experimentais de temperatura e tensão de vapor d'água obtidos no interior de uma cultura de milho (Zea mays, L.), variedade Cargil 111. A influência das modificações introduzidas na técnica de plantio (orientação das plantas e espaçamento), nestes processos de transporte, é observada ao analisar três tratamentos diferentes. 


\section{REVISÃO DE LITERATURA}

A interação de um fluxo de ar com uma superfície rugosa qualquer, implica em uma transferência de momentum do vento para superfície. Numa comunidade vegetal este fenomeno contribui enormemente para os movimentos turbulentos res ponsāveis pelos fluxos verticais de massa e energia.

Ao se considerar o interior de uma cultura, ob serva-se que os fluxos não possuem as mesmas características verificadas acima da superfície vegetada. 0 fluxo de ar no interior da comunidade vegetal ao interagir com os elementos da cultura é modificado, gerando fontes e sorvedouros de enex gia e massa nesta região. Assim sendo, os processos de trans porte de massa e energia no interior do dossel envolvem movimentos mais complexos, que ainda carecem de um conhecimento sa tisfatōrio.

BAINES (1972) questiona a origem do movimento 
turbulento responsável pelos processos de transferência no in terior da cultura, se seria devido à turbulência atmosférica ou à gerada pelas próprias plantas.

DYER (1974) atribuiu o interesse no estudo das relações fluxos-gradientes tanto ao reconhecimento da impor tância dos fluxos de massa e energia para a compreensão do comportamento da atmosfera próxima a superfície, como à estimativa destes fluxos a partir de modelos que envolvem determi nados parâmetros.

Os estudos da natureza do microclima de uma cul tura, tais como regime de radiação solar, temperatura, umidade, dióxido de carbono e vento podem fornecer informações sobre as respostas das plantas ao meio ambiente. Estas informa ções são essenciais para o aperfeiçoamento da arquitetura das plantas e o desenvolvimento de novas técnicas, possibilitando assim, um melhor aproveitamento das condições ambientais exis tentes.

A simulação de microclimas a partir de cālcu los de fluxos é um trabalho interessante, entretanto é mais simples medir os elementos que caracterizam o microclima a a partir daí, estimar os fluxos. A principal limitação dos modelos microclimáticos está no desconhecimento do comportamento de $r_{s}$ (resistência estomática) ao longo da cultura, pois di ficilmente é medida com uma precisão adequada (MONTEITH, 1973). 
DYER (1974) ressalta que atualmente, mesmo com o desenvolvimento da técnica da correlação turbulenta, que per mite medir os fluxos diretamente, ainda existe um interesse no estudo das relações fluxos-perfis. Alguns trabalhos teóri cos apresentam resultados aceitáveis, entretanto verifica-se uma discrepância ao se considerar os dados obtidos em vários trabalhos experimentais.

Inicialmente os estudos de fluxos restringiamse às regiões acima da cobertura vegetal. 0 estudo de perfis, nestas regiões, fornecia algumas informações satisfatórias so bre a interação da cultura com o meio ambiente.

vários métodos teem sido desenvolvidos para me didas de fluxo tanto acima como no interior de culturas. Os métodos empregados em estudos acima de superfícies vegetadas até pouco tempo atrás, não eram utilizados no interior destas superfícies. Provavelmente, devido tanto à complexidade da es trutura das plantas, como à diferenciação fisiolögica em cama das existentes, tornando os fluxos gerados no interior da cul tura processos mais complexos (JONHSON et alii, 1976; BILL et alii, 1976).

o método aerodinâmico empregado para cálculos de fluxos acima de culturas envolve coeficientes de transporte. As funções de estabilidade atmosférica são introduzidas para condições não adiabáticas. 
o grande número de estudos envolvendo as relações entre os coeficientes de transporte de momentum, calor e vapor d'água, tanto para condições adiabáticas como não adiabáticas, nem sempre apresentam os mesmos resultados, dificultando a interpretação dos resultados obtidos (PRUITT et alii, $1973)$.

DYER e HICKS (1970) mencionam a dificuldade de decidir qual a melhor descrição física do fenômeno de trans porte diante do grande nümero de relações fluxos-gradientes que tem aparecido. Algumas teem caráter estritamente empírico, outras envolvem um embasamento teórico, mas ambas, gera1mente, fazem restrições em relação aos coeficientes de transporte.

Os métodos micrometeorológicos geralmente us a dos na determinação de fluxos acima e no interior de culturas, admitem a inexistência de fluxos horizontais. BYRNE e ROSE (1972) apresentam um exemplo que evidencia a presença destes fluxos. Ressaltam a importância de se verificar a validade desta consideração antes e durante o experimento. Os fluxos horizontais podem ser identificados utilizando-se de fontes de fumaça na área do experimento.

Segundo DYER (1974) o cálculo de fluxos ou dos coeficientes de transporte se reduz ao conhecimento das fun ções universais $\emptyset_{M}$ (função de estabilidade para a troca de mo mentum), $\emptyset_{\mathrm{H}}$ (função de estabilidade para troca de calor) e $\phi_{W}$ 
(função de estabilidade para troca de vapor d'água), associadas ao parâmetro de estabilidade atmosférica Z/L, sendo L o comprimento de estabilidade de Monin-obukhov. Investigando os valores destas funções, considera os estabelecidos por DYER e HICKS (1970) os mais confiáveis, enquanto que os determinados por BUSINGER et alii (1971) exigem maiores estudos. Vários es tudos teem sido feitos visando também obter relações generali zadas para fluxos acima de culturas em diferentes situações, utilizando-se das funções de estabilidade. Entre outros, pode-se destacar os de PRUITT et alii, 1973; DYER, 1970; HÖGSTRÖM, 1974 .

Em estudos de trocas de momentum, massa e ener gia, numa comunidade vegetal, ressaltando a importância da ae rodinâmica da cultura nestes processos, THOM (1972) apresenta equações de fluxos em função de resistências fisiológicas e aerodinâmicas.

A descrição precisa dos processos turbulentos no interior de uma cultura ainda carece de uma teoria adequada, devido a complexidade dos fatores envolvidos e a dispersão dos dados obtidos.

Os métodos de estimativa de fluxos acima de cul turas não são utilizados no interior, embora possa se associar à massa vegetal parâmetros semelhantes a $z_{0}$ (comprimento de rugosidade), d (deslocamento do plano zero) e rc (resistência da cultura) associados a geometria e fisiologia das plantas (MONTEITH, 1973 ). 
Para velocidade de vento no interior da cultura não se verifica o perfil logarítmico, estando esta observa ção associada ao aparecimento de fontes e sorvedouros de mo mentum nesta região. Alguns estudos da variação do fluxo de momentum ou perfis de vento no interior de uma comunidade vegetal teem demonstrado um decréscimo exponencial destas grandezas, a medida que se penetra na cultura (CIONCO, 1972; SHAW et alii, 1974; BILL et alii, 1976; UCHIJIMA, 1976; HICKS e SHEIH, 1977).

SHAW et alii (1974) medindo a intensidade de turbulência relativa em três direções, acima e no interior de uma cultura de milho, observaram sempre valores maiores no in terior da cultura para as três componentes, aumentando a medi da que se aproxima da superfície do solo.

BAINES (1972) em estudos da turbulência no interior de uma cultura de trigo, utilizando-se de anemômetros de fio quente, sugere que a turbulência no interior é proveni ente, também, da interação da turbulência atmosférica com os elementos da cultura. Evidencia a importância da intensidade da turbulência na transferência de energia e massa entre as plantas e a atmosfera, ao observar os efeitos deste fator nes tes processos.

A determinação da distribuição vertical do coe ficiente de transporte (K) é uma das principais dificuldades no cálculo dos fluxos no interior de uma superfície vegetada. 
Este coeficiente estā associado à aerodinâmica da cultura e influencia as características dos processos turbulentos no in terior do dossel vegetativo.

LEMON (1969) destaca a necessidade de se conhe cer o valor exato de K, para obtenção de dados de fluxos confiáveis, e o uso de modelos visando predizer o microclima ou os processos de transferência numa comunidade vegetal. Para demonstrar a ligação de $\mathrm{K}$ com a aerodinâmica da cultura, apre senta os perfis de $K$ obtidos para duas culturas diferentes, com perfis de vento semelhantes, mas diferentes distribuições da área foliar. A importância da distribuição da área foliar é evidenciada ao observar perfis de $K$ bem distintos. Este fa to é atribuido a diferença entre os coeficientes de atrito das folhas e caules $\left(C_{D}\right)$. Ao comparar os perfis de temperatura e dióxido de carbono, verifica-se que a estrutura da cultura é um fator determinante no microclima e consequentemente, dos processos de transferência.

A maior parte dos trabalhos envolvendo medidas de $K$ no interior de culturas utilizam-se dos métodos do balan ço de momentum e balanço de energia. Entre outros pode-se cí tar os de BROWN e COVEY, 1966; WRIGHT e BROWN, 1967; THOM, 1971)

UCHIJIMA (1976) apresenta os resultados obti dos em vários estudos com milho e arroz, durante o período di urno, utilizando-se do método do balanço de energia na estima 
tiva de $\mathrm{K}$ no interior da cultura. Verificou que para $z$ (distância à superfície do solo) acima de $0,3 \mathrm{~h}$ (h=altura da cul tura), aproximadamente, K decresce exponencialmente com a posição segundo a equação:

$$
K(z)=K(h) \exp [-n(1-z / h)] \quad z \leqslant h
$$

onde $K(h)$ é o coeficiente de transporte no topo da cultura e $\eta$ o coeficiente de atenuação. Os valores de $\eta$ encontrados va riam de 2,5 a 3 . Vários trabalhos evidenciam que a variação de $\eta$ está associada à estrutura da cultura e às condições meteorológicas, principalmente à estratificação térmica.

DENMEAD (1976) apresenta resultados de estudos da variação de $K$ no interior de culturas de trigo, obtidos pe lo método do balanço de energia. Verificou o decaimento expo nencial com a posição, encontrando $\eta$ entre 2,2 e 3,3 .

GILLESPIE e KING (1971) combinando medidas da deposição de orvalho sobre as folhas, área foliar e gradien tes de umidade obtiveram o perfil noturno de K. Os valores de K encontrados foram maiores que o da difusão molecular de vapor d'água no ar, indicando assim, ser o processo de difusão no interior de uma cultura de carater turbulento. A forma do perfil observado não segue a relação exponencial, apresentando um mínimo próximo a região média da cultura. Os fluxos de calor sensível foram obtidos considerando $K_{H}$ (coeficiente de transporte de $\operatorname{calor}$ ) $=\mathrm{K}_{W}$ (coeficiente de transporte de vapor d'água). Verificaram que o calor sensível (H) é uma fonte de 
energia mais intensa para cultura durante a noite que o calor latente (LE). As fontes e sorvedouros de LE apresentaram mais regularmente distribuídas em relação as de H. Segundo os autores, estes resultados concordam com os obtidos para perío dos diurnos por UCHIJIMA (1966) e DENMEAD (1964).

$$
\text { BROWN e COVEY (1966) utilizando-se do método }
$$

do balanço de energia na estimativa de LE e H no interior de uma cultura de milho, verificaram que os valores de K obtidos ao serem ajustados a equação exponencial apresentaram um coeficiente de atenuação igual a 2,6 .

Visando o cálculo de fluxos de $\mathrm{CO}_{2}$ no interior de uma cultura de cevada, JonHSON et alie (1976) estimaram o perfil da difusividade turbulenta (K) pelo método do balanço de energia e pela medida do fluxo de $\mathrm{CO}_{2}$ através da técnica de BISCOE et alii (1975). Ao se comparar os resultados obtidos verificou-se que os perfis de $K$ são semelhantes, divergindo nos valores numéricos sendo mais significativa esta discrepân cia para as regiões mais baixas da cultura. 0 valor de $\mathrm{K}$ no topo da cultura foi obtido pelo método aerodinâmico. os valo res de K, neste ponto, obtidos pelos outros dois métodos concordam com o obtido pelo método aerodinâmico. As discrepân cias observadas não são atribuídas a erros experimentais, sugerindo que a heterogeneidade da cultura pode provocar fluxos horizontais ou invalidar os perfis de $\mathrm{K}$ no interior da cultura. Esta observação evidencia a idéia de LEGG e LONG (1975) 
de que não se pode utilizar as equações unidimensionais para as partes mais baixas da cultura.

$$
\text { WRIGHT e BROWN (1967) determinaram o perfil de }
$$

K em uma cultura de milho, utilizando-se dos métodos do balan ço de energia e balanço de momentum. Observaram uma maior concordância entre os valores de K encontrados, pelos dois mé todos, nas partes mais superiores da cultura. Aproximadamente $9 / 10$ desta ajusta-se à relação exponencial, sendo $\eta=2,88$. Medindo $K$ no topo da cultura pelos dois métodos a diferentes velocidades do vento verificaram uma pequena concordância para velocidades mais altas. Concluiram que o método do balanço de energia é mais preciso para baixas velocidades do vento e o de momentum para velocidades maiores. Os coeficientes de atrito, $C_{D}$, foram obtidos utilizando-se do método de balanço de energia. Observaram uma variação com a posição e a veloci dade do vento. As discrepâncias nas partes mais inferiores fo ram atribuídas à presença de convecção livre.

Medindo os coeficientes de atrito $\left(C_{D}\right)$ dos ele mentos de uma cultura artificial, num tūnel de vento, THOM (1971) verificou a variação de $C_{D}$ com a velocidade do vento. os resultados obtidos para $C_{D}$, no túnel de vento, foram utili zados para determinação do perfil de k em uma cultura de feijão. Verificou que para h/3< $<<$ h o coeficiente $k_{m}$ (coeficiente de transporte de momentum) não varia com a posição, dis cordando assim da equação exponencial verificada por vārios 
autores, ao utilizarem o método do balanço de energia ou do balanço de momentum.

Um método para determinação da distribuição de K ao longo de uma cultura é apresentado por LEgG (1975). Con siste em produzir um fluxo controlado de óxido de nitrogênio IV $\left(\mathrm{NO}_{2}\right)$ e medir a variação de sua concentração com a altura. $\mathrm{O} \mathrm{NO}_{2}$ apresenta as vantagens de não interagir com as plantas, é fácil de ser detectado e sua concentração natural na atmosfera é despresível. o autor observou que o método devido ao decréscimo da concentração de $\mathrm{NO}_{2}$ com a altura, dificultando assim a detecção nas partes mais superiores, oferece resultados mais precisos para as regiões mais inferiores, abaixo de $1 \mathrm{~m}$ aproximadamente. Sugere que o método pode ser utilizado co mo complemento dos métodos do balanço de momentum ou balanço de energia, em determinações nas regiões mais inferiores da cultura, onde estes métodos teem-se demonstrado mais imprecisos.

LEGG e LONG (1975) apresentam os resultados da distribuição vertical de $K$ no interior de uma cultura de trigo, obtidos por quatro métodos: método de 1 iberação de Nor, balanço de momentum, balanço de energia e perfil do vapor d'á gua. Os resultados obtidos com o método de perfil de Non e ba lanço de energia são considerados os mais confiáveis. Observou-se, para o método de $\mathrm{NO}_{2}$, que K decai com a altura segundo a relação exponencial, sendo $\eta=3,9$, discordando assim, 
das observações de THOM (1971). A forma $S$ do perfil de K obtida em outros trabalhos, como em GILLESPIE e KING (1971), é atribuida às condições de estabilidade térmica. Visando rela cionar o coeficiente de transporte no interior da cultura com a velocidade do vento e o gradiente de temperatura, verificou se a importância da estabilidade térmica. Ressalta a necessi dade de relacionar $K$ com as variações de estabilidade da at mosfera e as fontes e sorvedouros, para que os perfis obtidos sejam vālidos na determinação dos fluxos. A partir dos dados obtidos pelos perfis e sua relação com as condições de estabi lidade da atmosfera, a seguinte relação para k é estabeleci d a :

$$
K(z)=K(h) \exp [-\gamma(1-z / h)] /(1-\beta R i)^{-n}
$$

onde $(1-\beta R i)^{-n}$ seria uma função de correção associada às con dições de estabilidade atmosférica, similar às usadas para as relações acima de culturas e $\gamma$ o coeficiente de atenuação.

A partir da necessidade de se obter métodos cạ pazes de predizer as trocas de massa e energia em diferentes culturas sob diferentes condições de convecção, SCHUEPP e WHI TE (1975) apresentam um modelo eletroquímico onde se pode controlar parâmetros tais como velocidade do vento, para de terminação do coeficiente de transporte para fluxos mais complexos. Este método consiste basicamente em medir o coeficiente de difusão dos íons de uma solução eletrolítica, que envolve uma cultura simulada. A principal desvantagem está na 
diferença entre a difusividade molecular dos íons no eletroli to e do calor e vapor d'água no ar.

Após estas considerações observa-se que a determinação do coeficiente de transporte no interior da cultura ē um problema de fundamental importância na determinação dos fluxos nesta região. Embora os métodos do balanço de energia e balanço de momentum sejam os mais utilizados, observa-se alguns resultados contraditórios. Evidencia-se a neces sidade de limitar as regiões e condições de validade destes métodos, investigar quais os fatores e como estes influenciam o comportamento de $K$, desenvolver novos métodos, contribuindo assim para uma formulação teórica adequada dos fenômenos de transporte no interior da cultura.

A forma dos perfis pode ser utilizada para 1ocalização de fontes e sorvedouros de massa ou energia no inte rior da cultura. Esta forma está intimamente ligada a distri buição da área foliar, visto ser esta a principal área de tro cas a superfície das folhas. No entanto, para a determinação da intensidade e da distribuição vertical das fontes e sorvedouros torna-se necessário o conhecimento da distribuição de $\mathrm{K}$ ao longo da cultura além dos perfis da propriedade em estudo.

UCHIJIMA (1976) apresenta os resultados obtidos em cultura de milho e arroz por FRANCESCHENI, 1959; UCHI- 
JIMA, 1963; GOON, 1969. Verifica-se que os perfis de tensão de vapor no interior das culturas de milho e arroz decrescem à medida que se afasta da superfície do solo, assim os fluxos de calor latente são dirigidos de baixo para cima durante o dia. 0 perfil diurno de temperatura para a cultura de arroz apresenta um máximo, enquanto que no milho decresce continuamente com a altura. As diferenças encontradas são atribuídas as condições hídricas do solo da cultura de milho. o fluxo de calor latente de baixo para cima começa na região entre $0,5 \mathrm{~h}$ e $0,8 \mathrm{~h}$. Verifica-se para o arroz, fluxo de calor sensível de baixo para cima na posição $0,4 \mathrm{~h}$ sendo oposto nas camadas inferiores, para a cultura de milho o fluxo de calor sensível aumenta com a a1tura.

\section{BROWN e COVEY (1966) verificaram que o perfil} de temperatura para o milho é aproximadamente isotérmico an tes do nascer do sol, com o decorrer do dia a altura da tempe ratura máxima no interior da cultura vai mudando, tornando a ser aproximadamente isotérmico no fim do dia.

No Brasil os estudos de transporte turbulento em culturas encontram-se ainda numa fase inicial. Entre outros estudos realizados nesta área pode-se citar os trabalhos de GRODZKI (1978), IDE (1978) e FROTA (1978). 
4. MATERIAL E METODOS

4.1. Materia1

Os dados utilizados neste trabalho foram obtidos por FROTA (1978). A seguir tem-se uma breve descrição do experimento realizado por este autor, apresentando os pontos considerados mais importantes para o presente estudo.

4.1.1. Caracterização das condições do experimento

$4 \cdot 1 \cdot 1 \cdot 1 \cdot$ Loca 1

o experimento foi conduzido no período de no vembro/77 a fevereiro/78, no campo experimental do Departamen to de Física e Meteorologia da ESALQ - USP, município de Pira cicaba, SP. 
As coordenadas geogräficas do local são:

$$
\begin{aligned}
& 33042^{\prime} \text { de } 1 \text { atitude Sul } \\
& 47^{\circ} 38^{\prime} \text { de latitude Oeste }
\end{aligned}
$$

Apresenta uma altitude de $576 \mathrm{~m}$. A ärea ocupada pelo experimento foi de $2.100 \mathrm{~m}^{2}(30 \times 70 \mathrm{~m})$, sendo que, as āreas adjacentes também foram cultivadas com milho.

$$
4 \cdot 1 \cdot 1 \cdot 2 \cdot \text { So } 10
$$

0 solo da área do experimento é classificado como Terra Roxa Estruturada, a nível do grande grupo pela comissão de solos, e Afesol, segundo a sétima aproximação (RANZANI et alii 1966).

o preparo do solo constituiu de uma aração e uma gradagem, seguida do destorroamento por meio de uma enxada rotativa, e a aplicação de herbicida.

\subsubsection{Cu1tura}

A cultura utilizada foi milho (Zea mays, L.) va riedade Cargil 111. As características desta variedade estão descritas em FROTA (1978), assim como a adubação efetuada antes do plantio. 


\subsubsection{Instrumentos}

\subsubsection{Anemômetros}

As medidas de velocidade do vento no interior e acima da cultura foram obtidas utilizando-se de um sistema fabricado pelo C. W. THORNTHWAITE ASSOCIATES, mode1o WPRS 160, situado no centro da ārea em estudo. Os anemômetros foram ins talados a $170,190,230,310,390$ e $470 \mathrm{~cm}$ acima da superfície do solo. A sensibilidade do sistema, segundo as curvas de ca 1ibração da fábrica é de mais ou menos $1 \%$.

\subsubsection{Psicrômetros}

Para as medidas de temperatura e tensão de vapor d'água do ar, utilizou-se de um conjunto de psicrômetros construídos com termopares cobre-constantum n? 24 AWG, instalados a $60,110,140,170$ e $210 \mathrm{~cm}$ da superfície do solo. A instal ação deste conjunto é apresentada por Frota (1978).

$$
\text { As temperaturas seca e úmida, foram medidas com }
$$
auxílio de um potenciômetro modelo 8690-2 da LEEDS E NORTHRUP, tendo como fundo de escala 0-100 mV e uma sensibilidade de $0,02 \mathrm{mV}$. 
4.2. Métodos.

0 estudo de fluxos de energia e massa no interior de uma cultura não é um problema simples, devido a com plexidade dos fatores associados a estes fluxos. Geralmente nestes estudos, admite-se que o comportamento dos fluxos de ar acima e no interior de uma superfície vegetada é semelhante. Assim as equações associadas às trocas de energia e massa entre a cultura e a atmosfera relacionam o fluxo da propri edade com o gradiente vertical. Para o fluxo de calor sensível (H) e fluxo de calor latente (LE), num certo tempo, tem se:

$$
\begin{array}{ll}
\mathrm{H}=-\rho_{\mathrm{a}} \mathrm{C}_{\mathrm{p}} \mathrm{K}_{\mathrm{H}} \frac{\mathrm{dT}}{\mathrm{d} z} & {\left[\mathrm{ca} 1 \cdot \mathrm{cm}^{-2} \cdot \mathrm{s}^{-}\right]} \\
\mathrm{LE}=-\frac{\rho_{\mathrm{a}} \mathrm{C}_{\mathrm{P}}}{\gamma} \mathrm{K}_{\mathrm{W}} \frac{\mathrm{de}}{\mathrm{dz}} & {\left[\mathrm{ca} 1 \cdot \mathrm{cm}^{-2} \cdot \mathrm{s}^{-}\right]}
\end{array}
$$

Onde: $\quad C_{p}=$ calor específico do ar a pressão constante

$$
\begin{aligned}
& \left(0,24 \text { cal } / \mathrm{g}^{\circ} \mathrm{C}\right) \\
\rho_{\mathrm{a}}= & \text { densidade do ar }\left(1,205.10^{-3} \mathrm{~g} / \mathrm{cm}^{3}\right) \\
\gamma= & \text { constante psicrométrica }\left(0,57 \mathrm{mmH} /{ }^{\circ} \mathrm{C}\right) \\
\mathrm{K}_{\mathrm{W}}= & \text { coeficiente de transporte de vapor d'ägua }\left[\mathrm{cm}^{2} . \mathrm{s}^{-}\right] \\
\mathrm{K}_{\mathrm{H}}= & \text { coeficiente de transporte de calor sensível }\left[\mathrm{cm}^{2} . \mathrm{s}^{-}\right] \\
\mathrm{dT} / \mathrm{d} z= & \text { gradiente vertical de temperatura }\left[{ }^{\circ} \mathrm{C} . \mathrm{cm}^{-}\right] \\
\mathrm{d} e / \mathrm{d} z= & \text { gradiente vertical de tensão de vapor d'ägua } \\
& {\left[\text { [mmH. } \mathrm{cm}^{-}\right] }
\end{aligned}
$$

A anālise dos perfis no interior da cultura per 
mite determinar a localização das fontes e sorvedouros de ca lor sensível e vapor d'ägua. Visto que $\rho_{a}, C_{p}, \gamma$ e os coeficientes de transporte são positivos, o sinal do fluxo é deter minado pelo sinal do gradiente, e a mudança de sinal indica a presença de fonte ou sorvedouro.

Diz-se que uma região é uma fonte de calor sen sível (vapor d'ägua), quando o fluxo vertical diverge nesta região, ou seja, o fluxo que entra é menor do que sai. A região de sorvedouro é caracterizada pela convergência do fluxo, o fluxo que entra é maior do que sai. Assim, a análise dos perfis de fluxos permite determinar a distribuição vertical das fontes e sorvedouros, pois as regiões caracterizadas por um gradiente vertical de fluxo positivo são fontes de calor (vapor d'água) e sorvedouros'de calor (vapor d'água) na pre sença de gradientes negativos. A intensidade da fonte ou sor vedouro é dada pelo módulo do gradiente vertical do fluxo.

$$
\text { Derivando a equação (1) em relação a altura } z
$$
e considerando $\rho_{a}$ e $C_{p}$ constantes no tempo e no espaço, temse:

$$
\frac{d H}{d z}=-\rho_{a} C_{p}\left(\frac{d K_{H}}{d z} \frac{d T}{d z}+K_{H} \frac{d^{2} T}{d z^{2}}\right)
$$

Analogamente tem-se para o calor latente.

$$
\frac{d L E}{d z}=-\rho_{a} C_{P}\left(\frac{d K_{W}}{d z} \quad \frac{d e}{d z}+K_{W} \frac{d^{2} e}{d z^{2}}\right)
$$

$$
\text { Observa-se nas equações (3) e (4) que o sinal }
$$


do gradiente vertical do fluxo não depende apenas do sinal do gradiente de temperatura ou tensão de vapor, mas também do si nal de $\mathrm{d}^{2} \mathrm{~T} / \mathrm{d} \mathrm{z}^{2}$ e $\mathrm{d}^{2} e / \mathrm{dz}^{2}$, visto que $\mathrm{dK}_{\mathrm{H}} / \mathrm{dz}$ e $\mathrm{dK}_{\mathrm{W}} / \mathrm{dz}$ são sem pre positivos ou nulos. Evidencia-se assima necessidade de se conhecer a distribuição vertical dos coeficientes $K_{H}$ e $k_{W}$ no interior da cultura ao se obter o perfil da intensidade das fontes e sorvedouros a partir dos perfis de temperatura e ten são de vapor.

4.2.1. Métodos de determinação de $K$ no interior da cul tura

A determinação do coeficiente de transporte no interior da cultura apresenta alguns problemas relacionados com a heterogeneidade da cultura, precisão de medidas entre outros. Uma determinação precisa do comportamento dos ks requeria medidas exatas de velocidade do vento, temperatura e $\underline{u}$ midade do ar, ou de fluxos implicando no uso de equipamentos bastante sensíveis. Além disso, as formulações teóricas destes processos ainda não são satisfatórias. A formulação de um modelo teórico adequado torna-se um problema complexo, pois são värios fatores interligados, tais como, densidade de plan tio, distribuição da área foliar e velocidade do vento, influ enciando estes processos.

Basicamente três métodos teem sido usados vi sando obter uma aproximação do comportamento dos coeficientes 
de transporte ao longo de uma cultura: método do balanço de momentum, método do balanço de energia e método das medidas de fluxos.

A fig. 1 apresenta um esquema dos métodos de balanço do momentum e energia baseado na representação de LEMON (1969) destes métodos para o cálculo do fluxo de $\mathrm{CO}_{2}$.

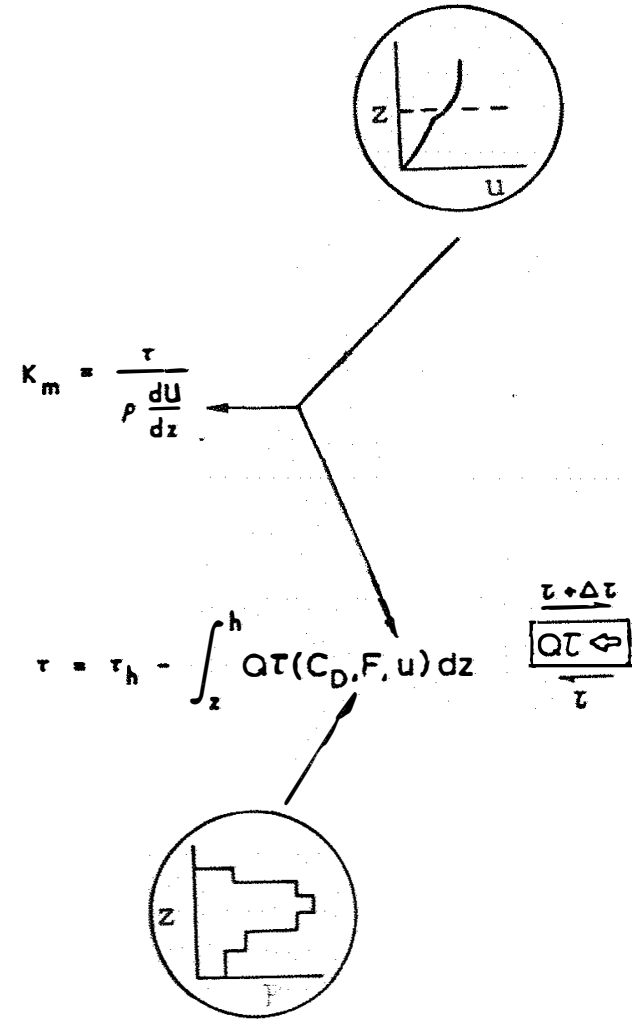

(a)

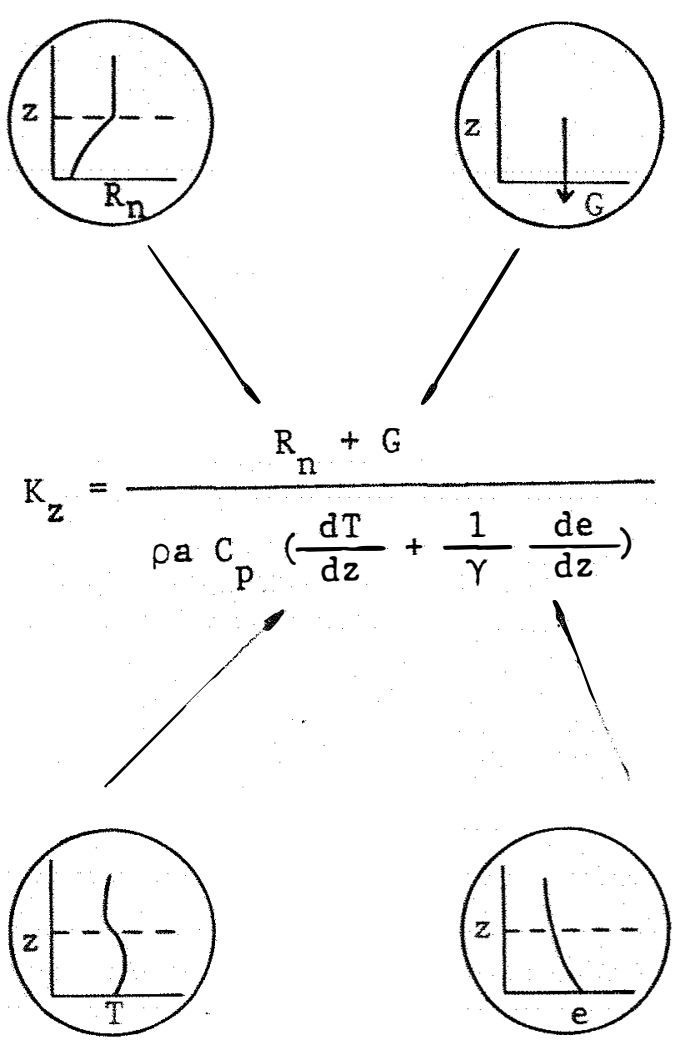

(b)

Fig. 1 - (a) Método do balanço de momentum

(b) Método do balanço de energia 
o método do balanço de momentum requer o per fil de vento acima e no interior da cultura e medidas da área foliar efetiva (F). Geralmente assume-se que $C_{D}$, coeficiente de atrito entre folhas e caules, $\bar{e}$ constante com a velocidade do vento (u) e a altura (z). Esta consideração é a principal limitação do método.

Para o método do balanço de energia são necessārias medidas no interior da cultura de temperatura e umidade do ar, radiação líquida (Rn) e fluxo de calor no solo (G). o valor $k_{z}$ obtido representa um coeficiente médio de transpor te de calor sensível e latente. A principal dificuldade deste método está na medida precisa da radiação líquida a dife rentes níveis.

A utilização do valor de K obtido por qualquer um dos métodos acima, para o estudo de fluxos de outras propri edades ou comparar os resultados, implica em admitir a simila ridade entre os processos de transferência envolvidos.

o outro método citado, método das medidas de fluxos, consiste em medir o fluxo e o gradiente da propriedade. Uma técnica utilizada para medidas de fluxo é o método da correlação turbulenta (SWINBANK, 1951). A determinação precisa de $K$, neste caso, exige medidas de fluxo com grande precisão, necessitando assim, de equipamentos de alta sensibi lidade. 
4.2.2. Método utilizado para determinação de $K_{H}$ e $K_{W}$ no interior da cultura

Neste trabalho, devido a falta de dados de radiação solar líquida, fluxo de calor no solo e área foliar ao longo da cultura, para determinação de $K(z)$ adotou-se a varia ção exponencial de $K(z)$ verificada por vários pesquisadores, já citados, para culturas de milho entre outras.

$$
K(z)=K_{h} e^{-n(1-z / h)} \quad z \leqslant h
$$

sendo: $\quad K_{h}=$ coeficiente de transporte no topo da cultura ( $z=h$ )

Ao se admitir a variação exponencial de K há necessidade de determinar qual o valor adequado de $n$, diante da inexistência de dados para determinā-1o e a variabilidade dos dados encontrados na literatura. Considerando os resulta dos apresentados por UCHIJIMA (1976) obtidos em vários estu dos com culturas de milho e arroz, onde $\eta$ varia de 2,5 a 3 , fez-se uma estimativa do erro associado a esta faixa de varia ६̧ão.

Sabe-se que para uma variável qualquer u fun ção das variáveis $x, y, z \ldots t$, isto é:

$$
u=f(x, y, z \cdots t)
$$

o erro absoluto máximo $\left(\Delta^{*} u\right)$ serä dado por:

$$
|\Delta * u|=\left|\frac{\partial u}{\partial x}\right||\Delta * x|+\left|\frac{\partial u}{\partial y}\right||\Delta * y|+\left|\frac{\partial u}{\partial z}\right||\Delta * z|+\ldots\left|\frac{\partial u}{\partial t}\right||\Delta * t|
$$


onde $|\Delta * x|,|\Delta * y|,|\Delta * z| \ldots|\Delta * t|$ são os erros absolutos mäximos associados às variáveis $x, y, z \ldots t$ respectivamente.

Considerando na equação (5) $k_{h}$ constante, temse que o erro máximo absoluto associado ao coeficiente de trans porte $K(z)$ é:

$$
|\Delta * K(z)|=\left|-\left(1-\frac{z}{h}\right)\right| k_{h} e^{-n\left(1-\frac{z}{h}\right)}|\Delta * n|
$$

Para a faixa de variação de n adotada tem-se:

$$
|\Delta * K(z)|=\left(1-\frac{z}{h}\right) \quad k_{h} e^{-\eta\left(1-\frac{z}{h}\right)} \quad 0,5
$$

Assim o erro relativo máximo é:

$$
\frac{|\Delta * K(z)|}{K(z)}=\left(1-\frac{z}{h}\right) \quad 0,5
$$

Logo tem-se para região de validade da equação (5) $(z>0,3 h)$ um erro percentual máximo de $35 \%$ sendo $z=0,3 h$, um erro aceitável dentro das condições da obtenção dos dados em estudo e outros fatores que não deixam de contribuir para imprecisão dos resultados tais como traçado dos perfis e a de terminação gráfica dos gradientes.

Diante destas considerações adotou-se na deter minação do perfil de $K(z)$ o valor médio 0,75 para $n$, assim:

$$
K(z)=K_{h} \quad e^{-0,75(1-z / h)}
$$


4.2.3. Determinação de $K(h)$

o coeficiente de transporte no topo da cultura foi determinado pelo método aerodinâmico:

$$
\mathrm{K}_{\mathrm{m}}(\mathrm{h})=\mathrm{k} \quad \mathrm{u} *(\mathrm{~h}-\mathrm{d})
$$

onde: $k=$ constante de $\operatorname{Von} \operatorname{Karmam}(0,41)$

$$
\begin{aligned}
& \mathrm{u}^{*}=\text { velocidade de atrito }\left[\mathrm{cm} \cdot \mathrm{s}^{-}\right] \\
& \mathrm{d}=\text { deslocamento do plano zero }[\mathrm{cm}]
\end{aligned}
$$

Os parâmetros micrometeorológicos d e u* utili zados são os determinados por FROTA (1978):

$$
\begin{aligned}
& u^{*}=30,05 \mathrm{~cm} / \mathrm{s} \\
& d^{*}=244 \mathrm{~cm}
\end{aligned}
$$

Pode-se admitir $K_{m}(h)=K_{H}(h)=K_{W}(h)$ visto que as velocidades do vento acima da cultura, verificadas por Fro TA (1978) são características de atmosfera neutra.

$$
\begin{aligned}
& \text { 4.2.4. Determinação dos fluxos e das intensidades das } \\
& \text { fontes e sorvedouros de calor sensivel (H) e } \\
& \text { calor latente (LE) }
\end{aligned}
$$

Utilizando-se dos perfis de temperatura e tensão de vapor d'água do ar, juntamente com o perfil do coefici ente de transporte determinou-se a partir das equações (1) e (2) os fluxos de calor sensivel e calor latente, à diferentes 
distâncias da superfície do solo e horārios. As equações (3) e (4) foram utilizadas na determinação das intensidades das fontes e sorvedouros. Em ambos os casos os gradientes necessārios foram obtidos graficamente.

4.2.5. Medidas de temperatura

Foram feitas medidas de temperatura seca e úmi da em mV de 15 em 15 min. Os valores apresentados para tempe ratura seca e úmida são médias de três medidas consecutivas. A conversão do dado de temperatura em $m V$ para oc foi feita utilizando-se da tabela de conversão, interpolando até $0,010^{\circ}$.

As tensões de vapor foram determinadas pela equação psicrométrica:

$$
e=e_{w}^{\prime}-\gamma\left(T_{S}-T_{u}\right)
$$

Sendo: $e_{x^{\prime}}=$ tensão de saturação a temperatura do bulbo úmido

$\gamma=$ constante psicrométrica

$\mathrm{T}_{S}=$ temperatura do bulbo seco

$\mathrm{T}_{\mathrm{u}}=$ temperatura do bulbo úmido

4.2.6. Medidas de velocidade do vento

As medidas de velocidade do vento foram feitas de 30 em $30 \mathrm{~min}$, e obtidas em contagens/min. Utilizando-se 
das curvas de calibração do instrumento os dados foram conve $\underline{r}$ tidos em cm/s.

o período de observação tanto para medidas de temperatura como de vento foi de 6 às 18 horas.

\subsubsection{Tratamentos estudados}

Fez-se medidas em três tratamentos diferentes:

Tratamento 1: Plantio orientado, isto é a orientação do plano das folhas é o mesmo das linhas. O espaçamento é de $80 \mathrm{~cm}$ entre 1 inhas e $20 \mathrm{~cm}$ entre covas. A densidade deste plantio é $125.000 / \mathrm{ha} \mathrm{em}$ 1251 inhas de $100 \mathrm{~m}$.

Tratamento 2: Plantio orientado, espaçamento de $100 \mathrm{~cm}$ entre linhas e $20 \mathrm{~cm}$ entre covas, apresentando uma den sidade de 100.000 plantas/ha em 100 linhas de $100 \mathrm{~m}$.

Tratamento 3: Plantio sem orientação (tradiciona 1), espaçamento de $100 \mathrm{~cm}$ entre 1 inhas e $20 \mathrm{~cm}$ entre covas. A densidade de plantio é de 100.000 plantas/ha, idêntica a do tratamento 2 .

A técnica de plantio empregada para se obter a orientação desejada é apresentada por FROTA (1978), assim como a descrição das parcelas estudadas. 
5. RESULTADOS

Os resultados aqui apresentados podem ser divi didos em duas partes distintas. A primeira parte constitui dos dados de temperatura e tensão de vapor d'água do ar, no in terior da cultura, obtidos experimentalmente por FROTA (1978).

os valores referentes ao dia $01 / 02 / 78$, devido apresentarem maior uniformidade nos diferentes tratamentos, fo ram utilizados tanto para a determinação dos fluxos de calor sensível e calor latente, como também, na distribuição vertical e as intensidades das fontes e sorvedouros de calor sensí vel e calor latente, segundo a metodologia empregada. Os resultados assim obtidos juntamente com a distribuição vertical do coeficiente de transporte, no interior da cultura, constituem a outra parte deste capítulo. 
5.1. Perfis de temperatura e tensão de vapor d'água no interior da cultura

Os valores de temperatura (T) e tensão de va por d'água (e) do ar, no interior da cultura, obtidos experimentalmente por FROTA (1978) estão nas tabelas 1 a 12 . Estes dados referem-se aos seguintes dias de observação: 26/01, 30/ $01,01 / 02$ e $08 / 02 / 78$.

Pode-se observar, nas figuras 2 a 4 , o comportamento diurno dos perfis de temperatura e tensão de vapor d'á gua no interior do dossel, no dia $01 / 02 / 78$, para os tratamentos estudados, em intervalos de tempo de 1 em 1 hora. 


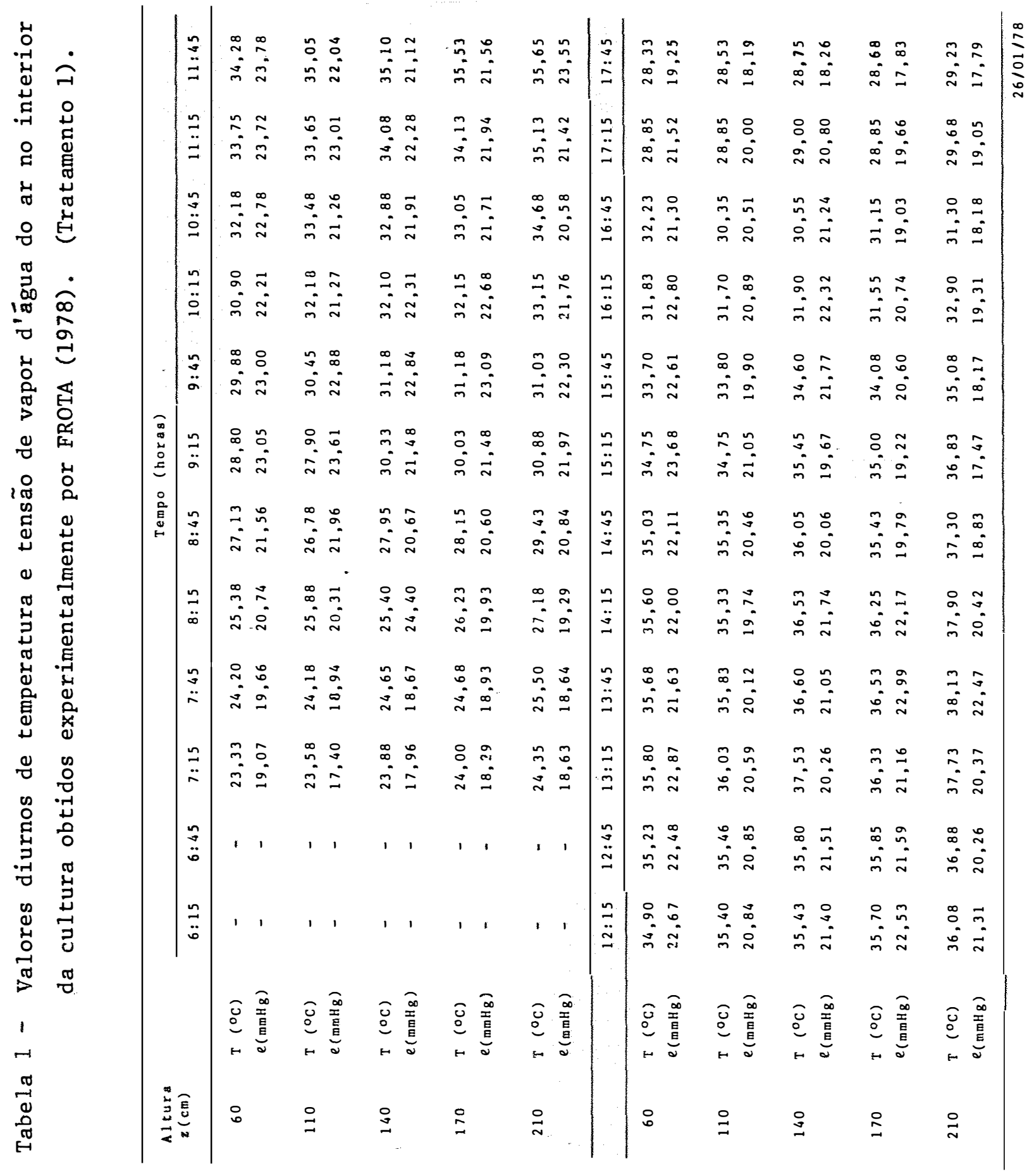




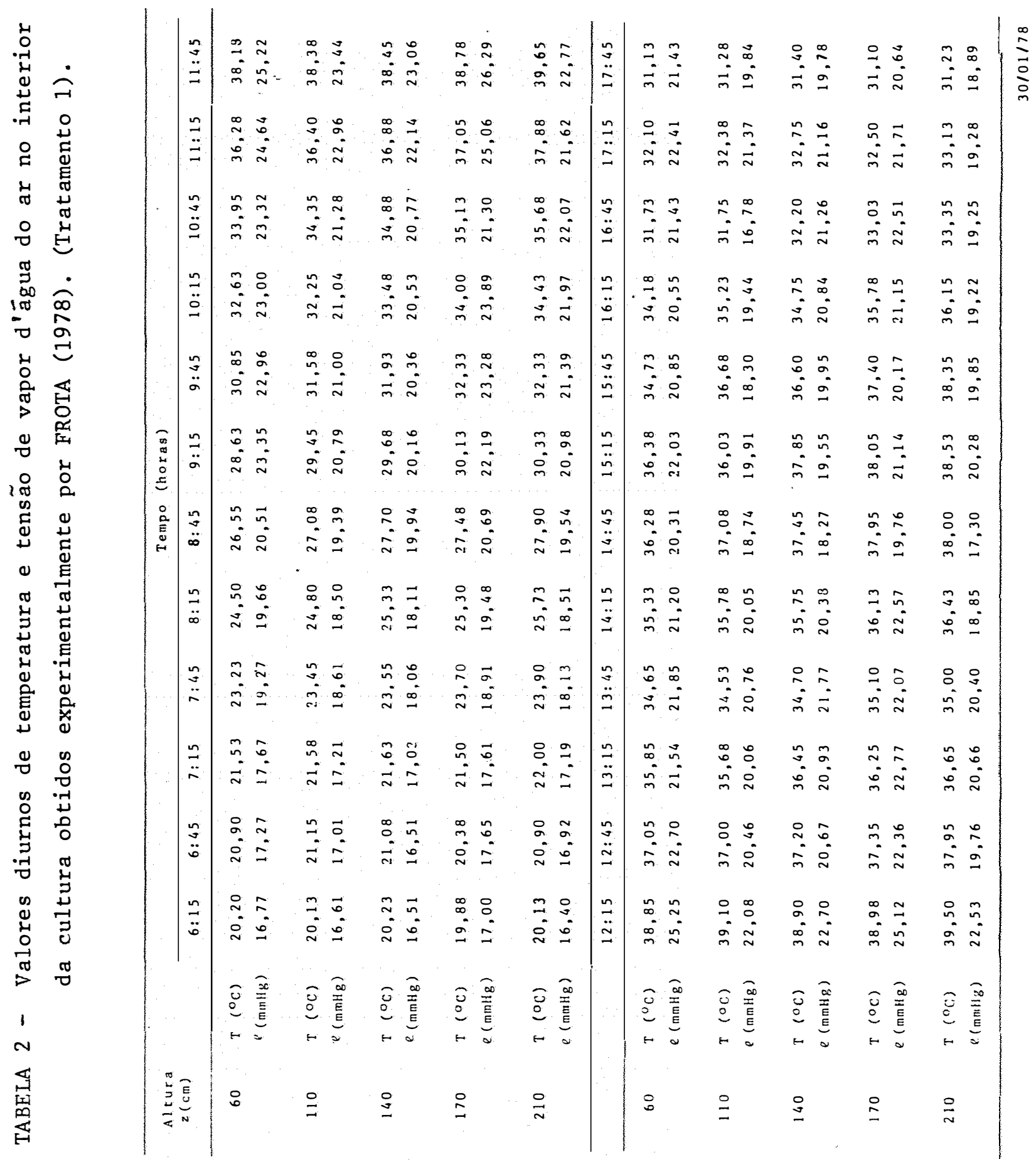




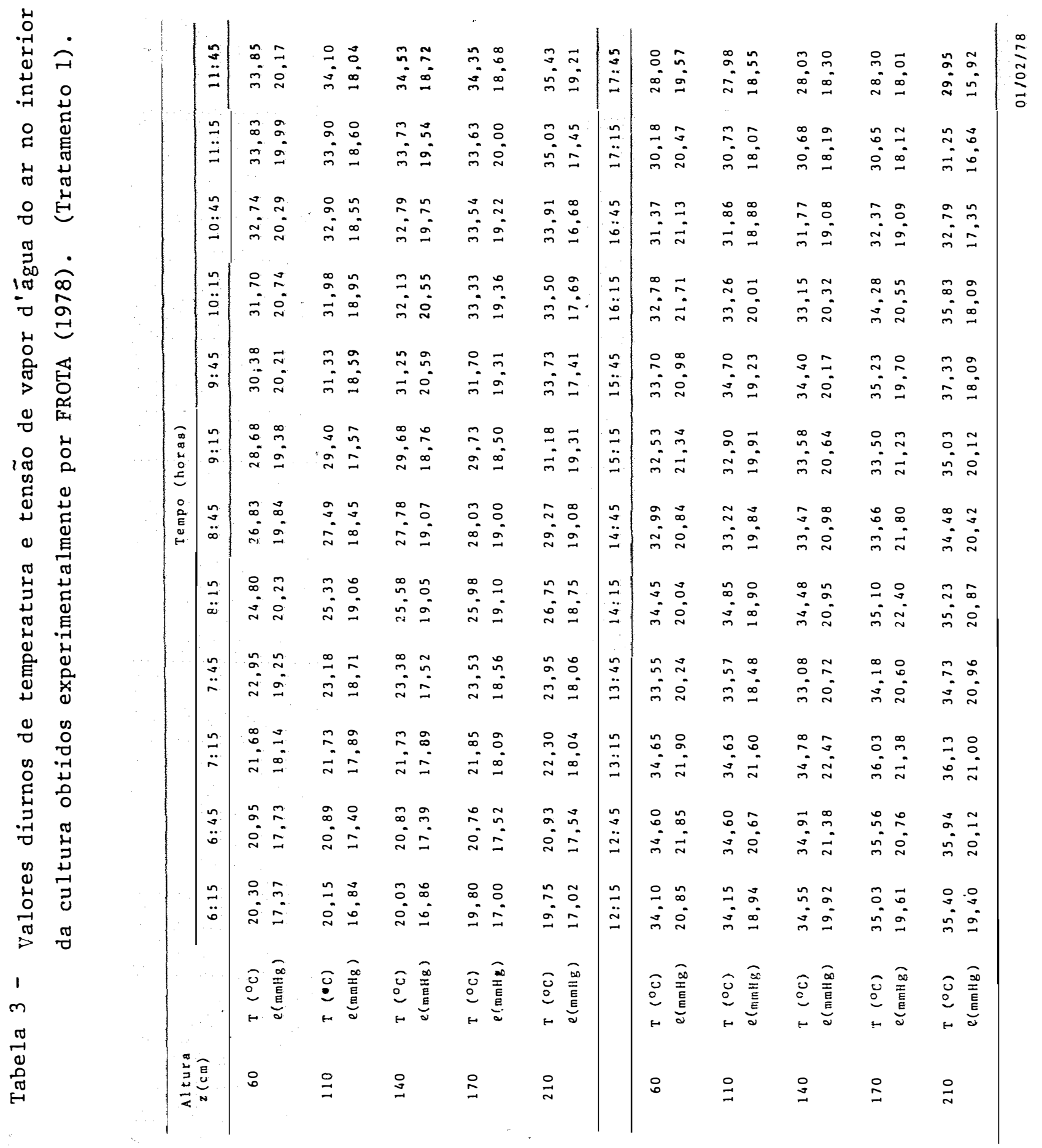




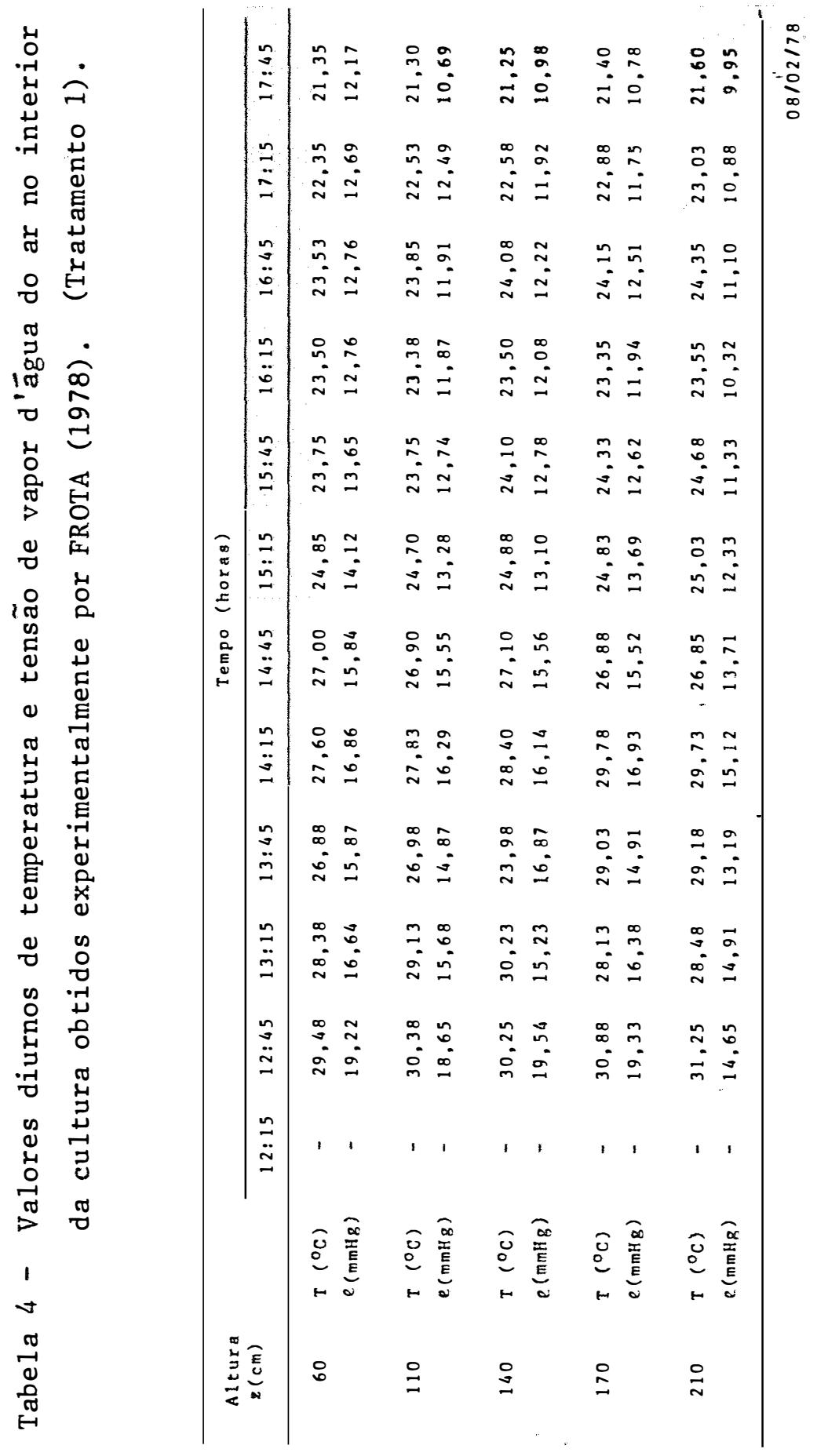




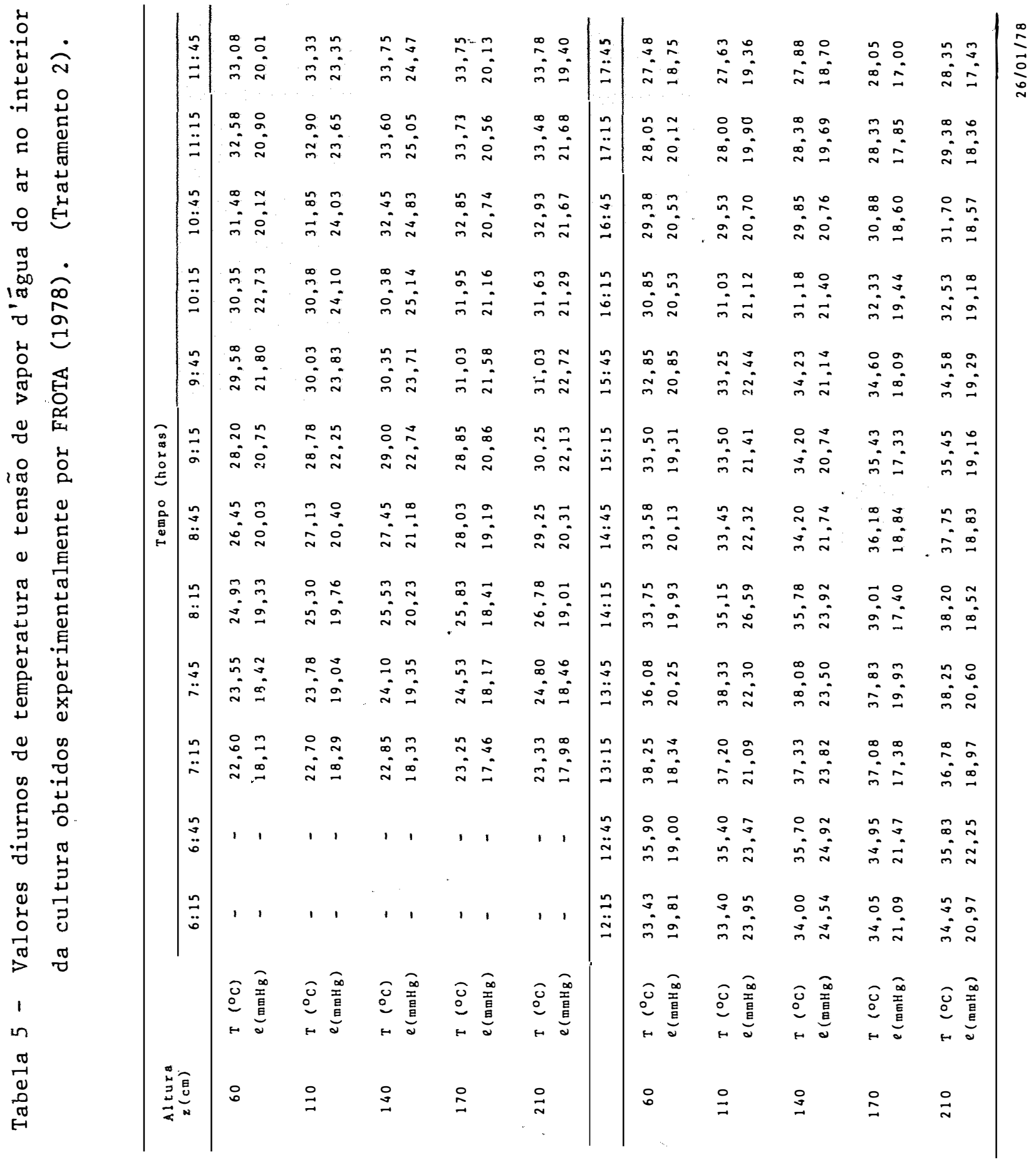




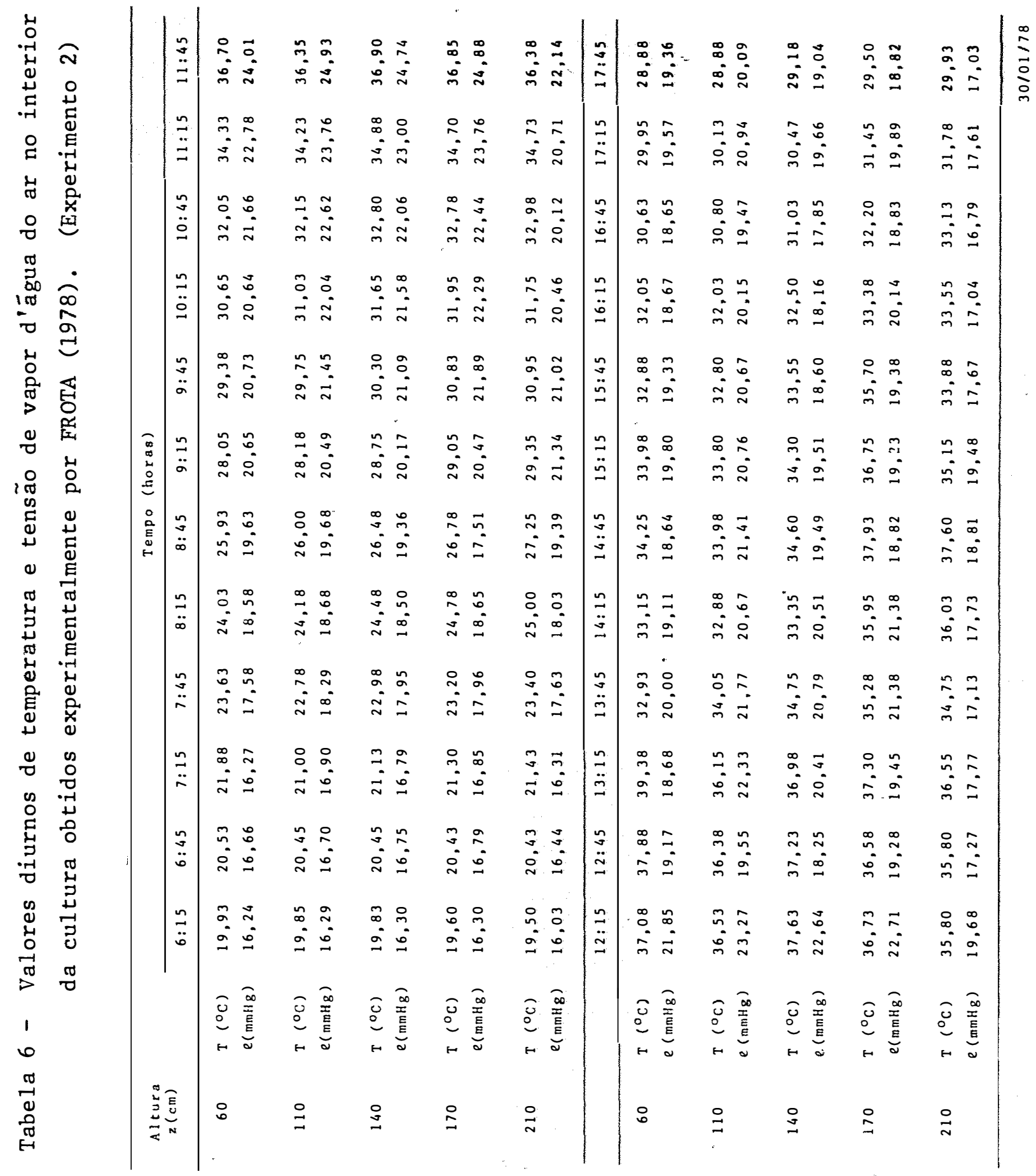




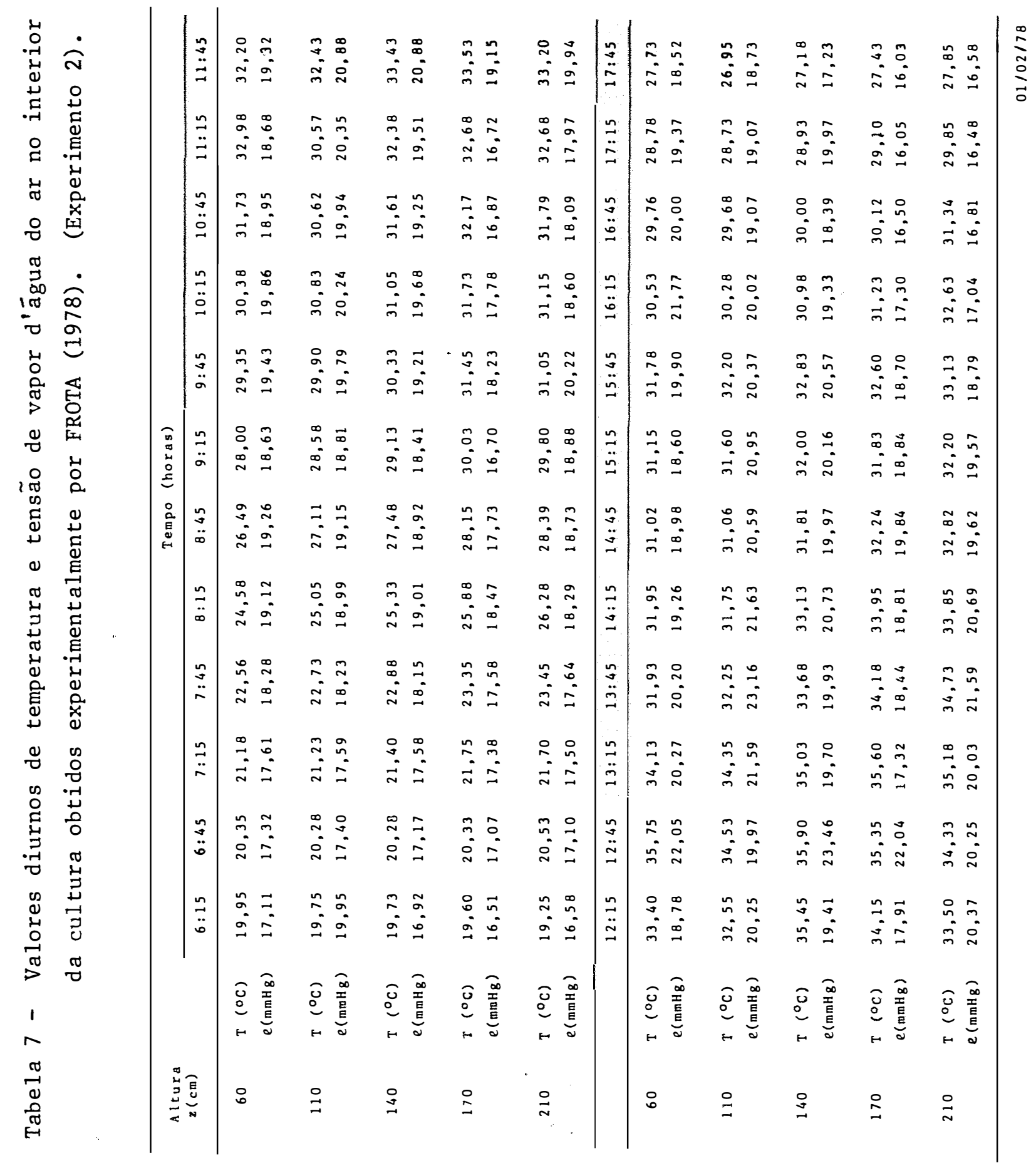




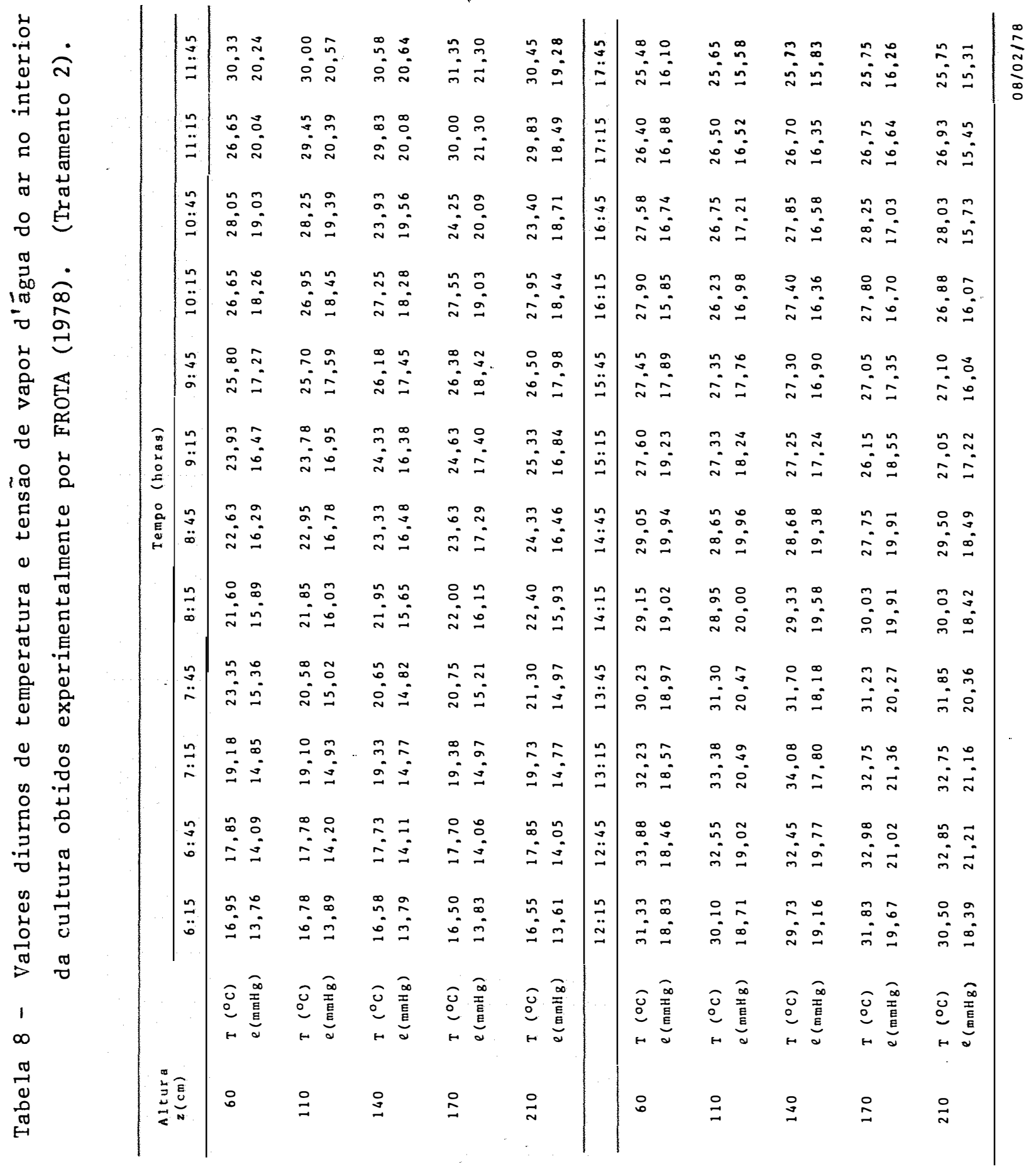




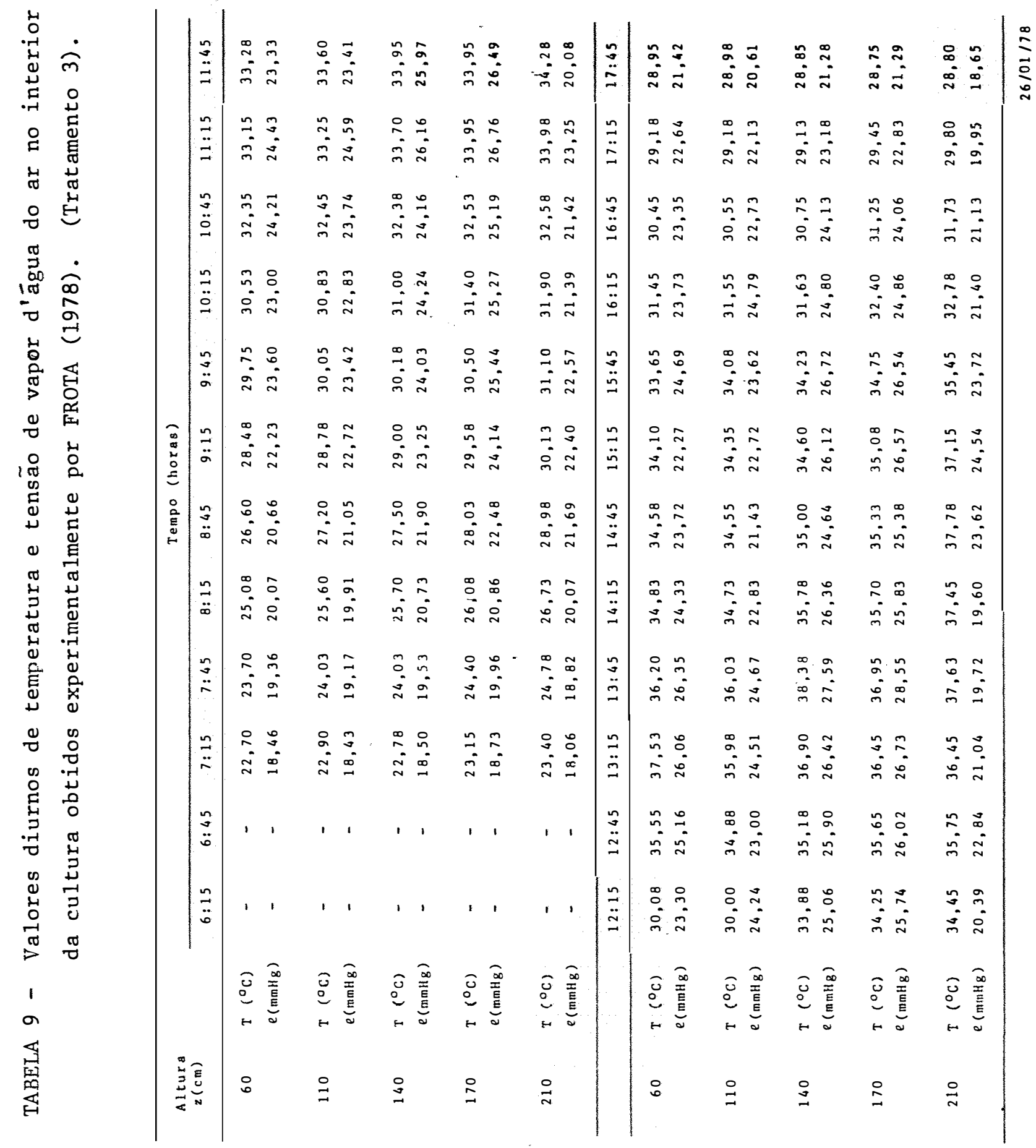




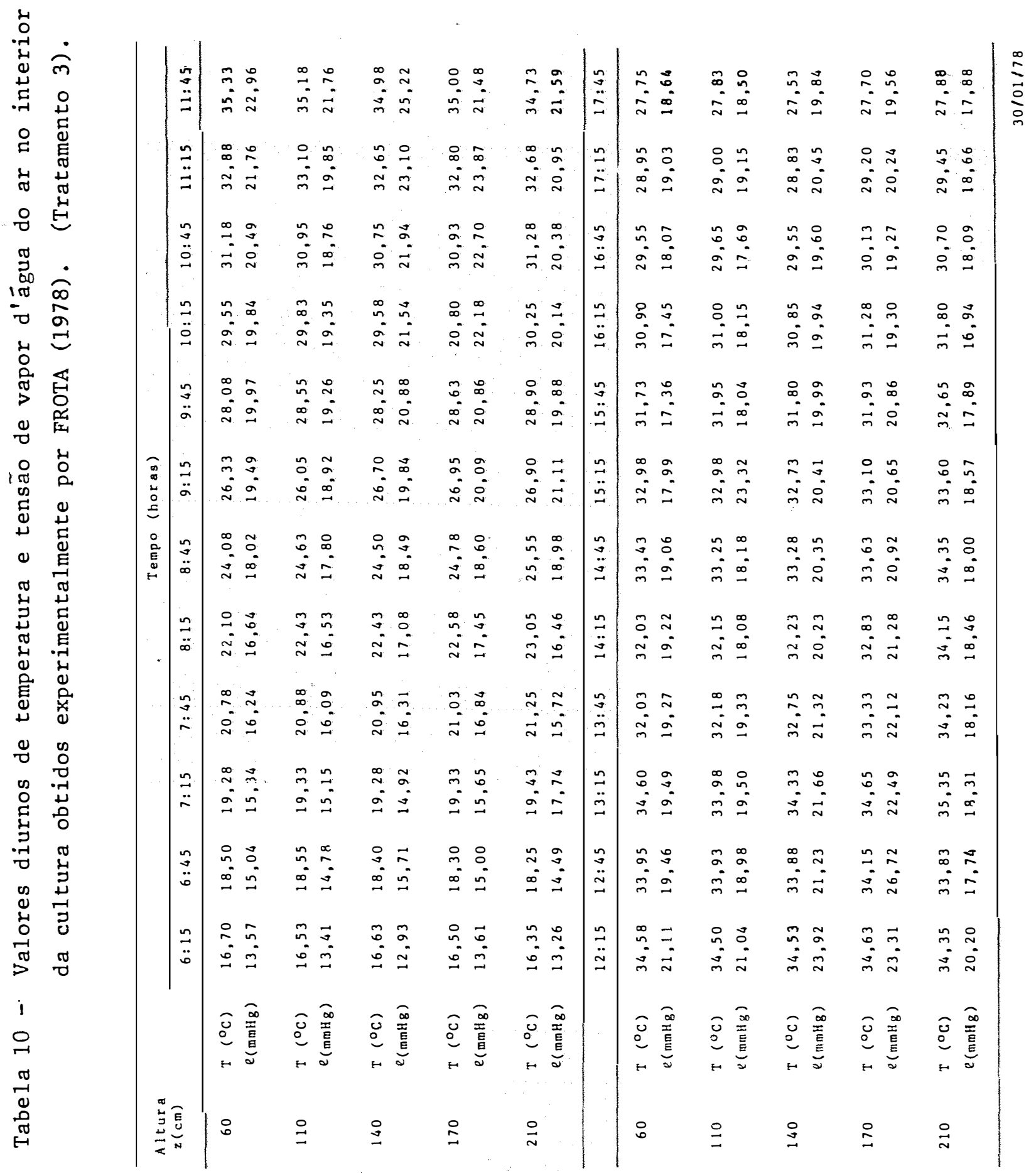




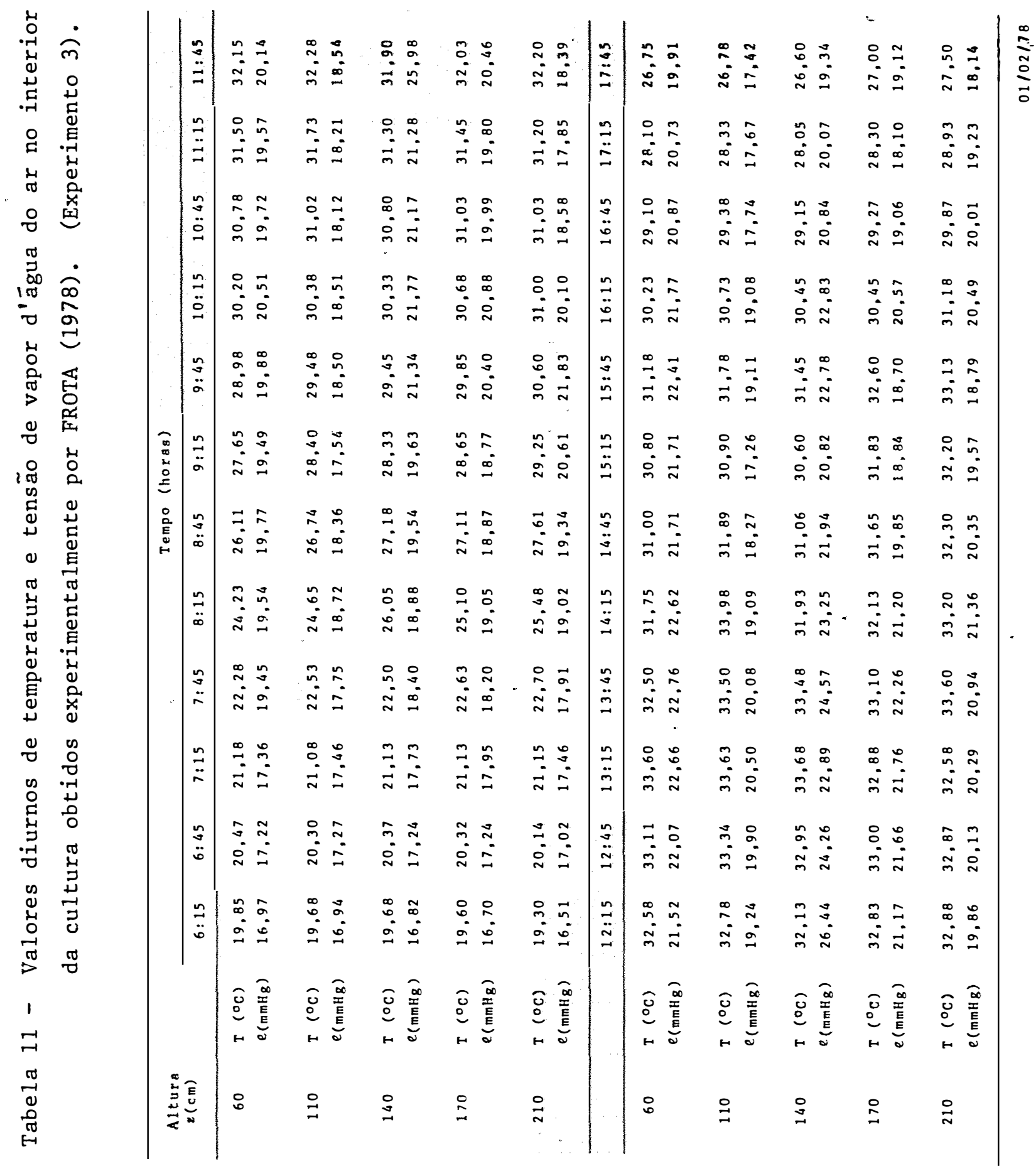




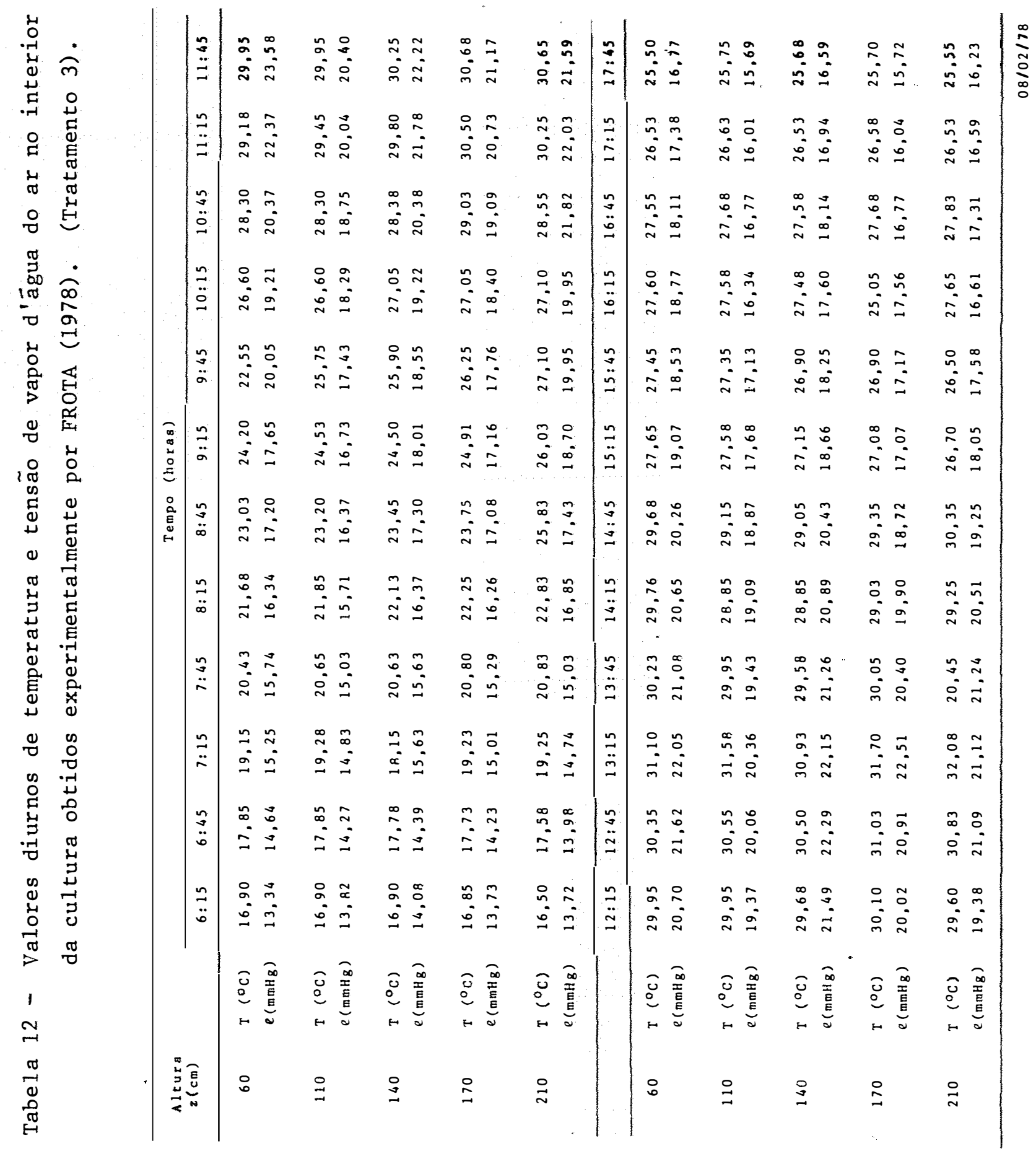



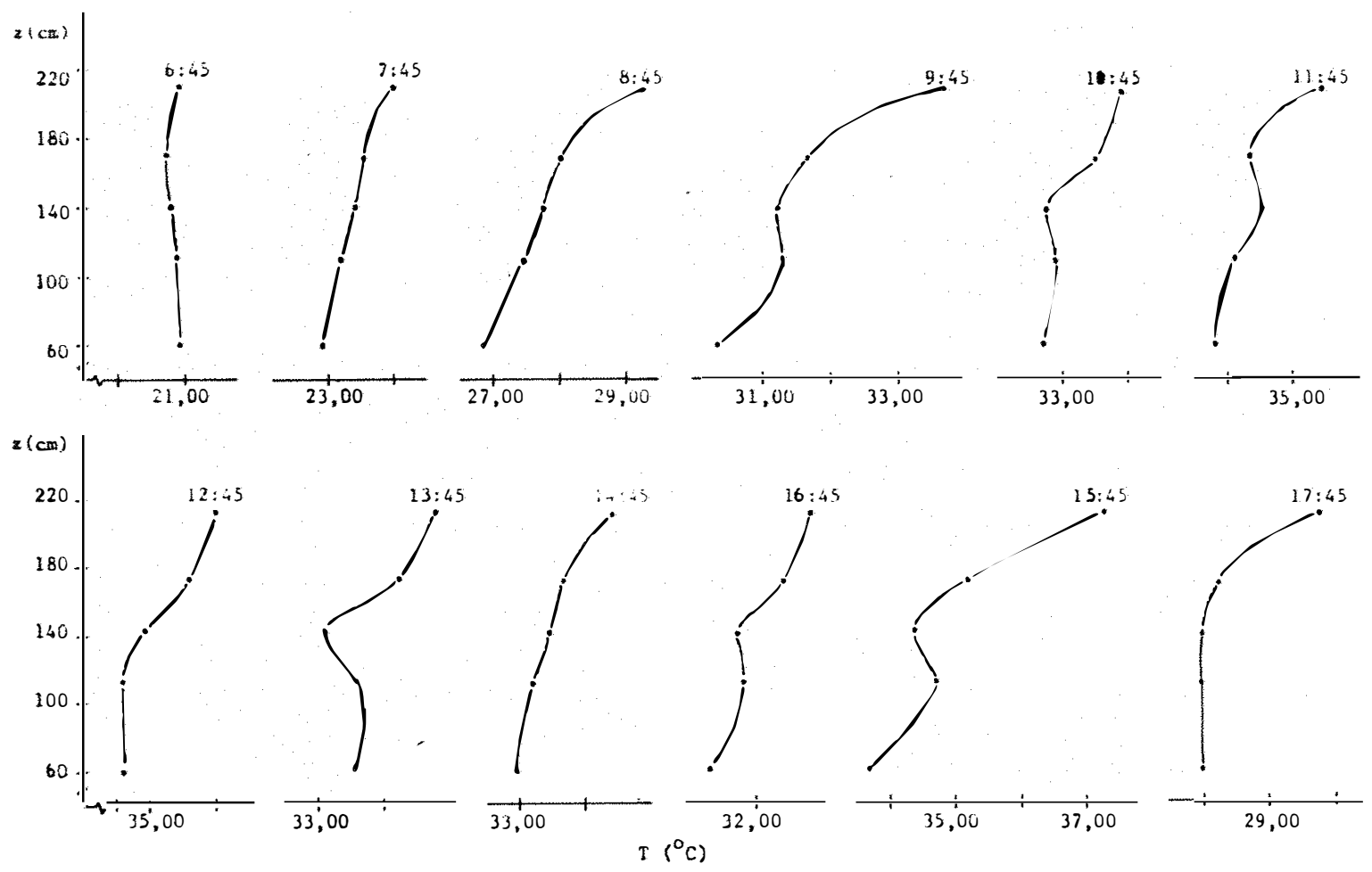

(a)
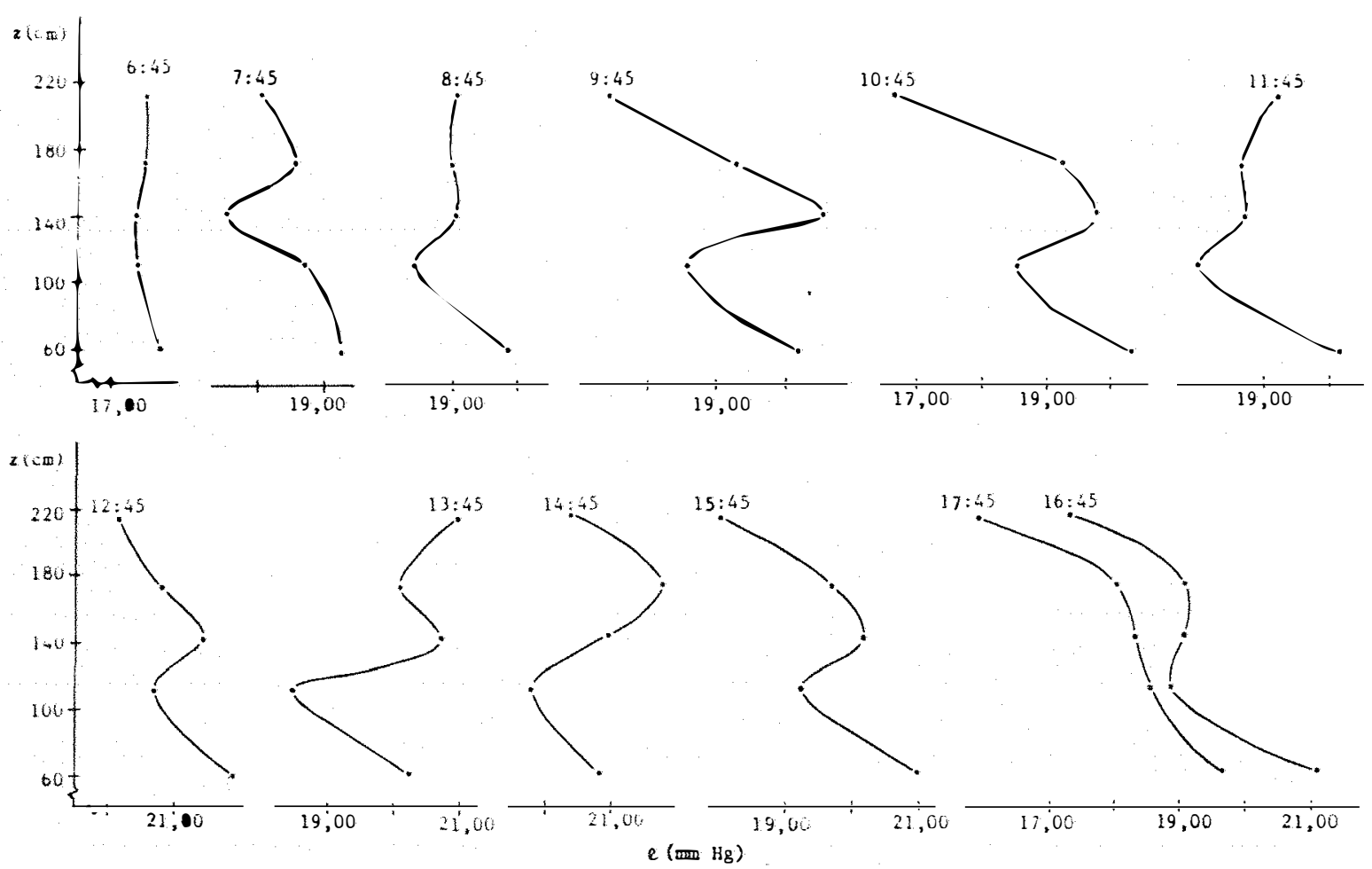

(b)

Figura 2 - Perfis de (a) temperatura e (b) tensão de vapor d'àgua no interior da cultura para diferentes tempos. (Tratamento 1) 

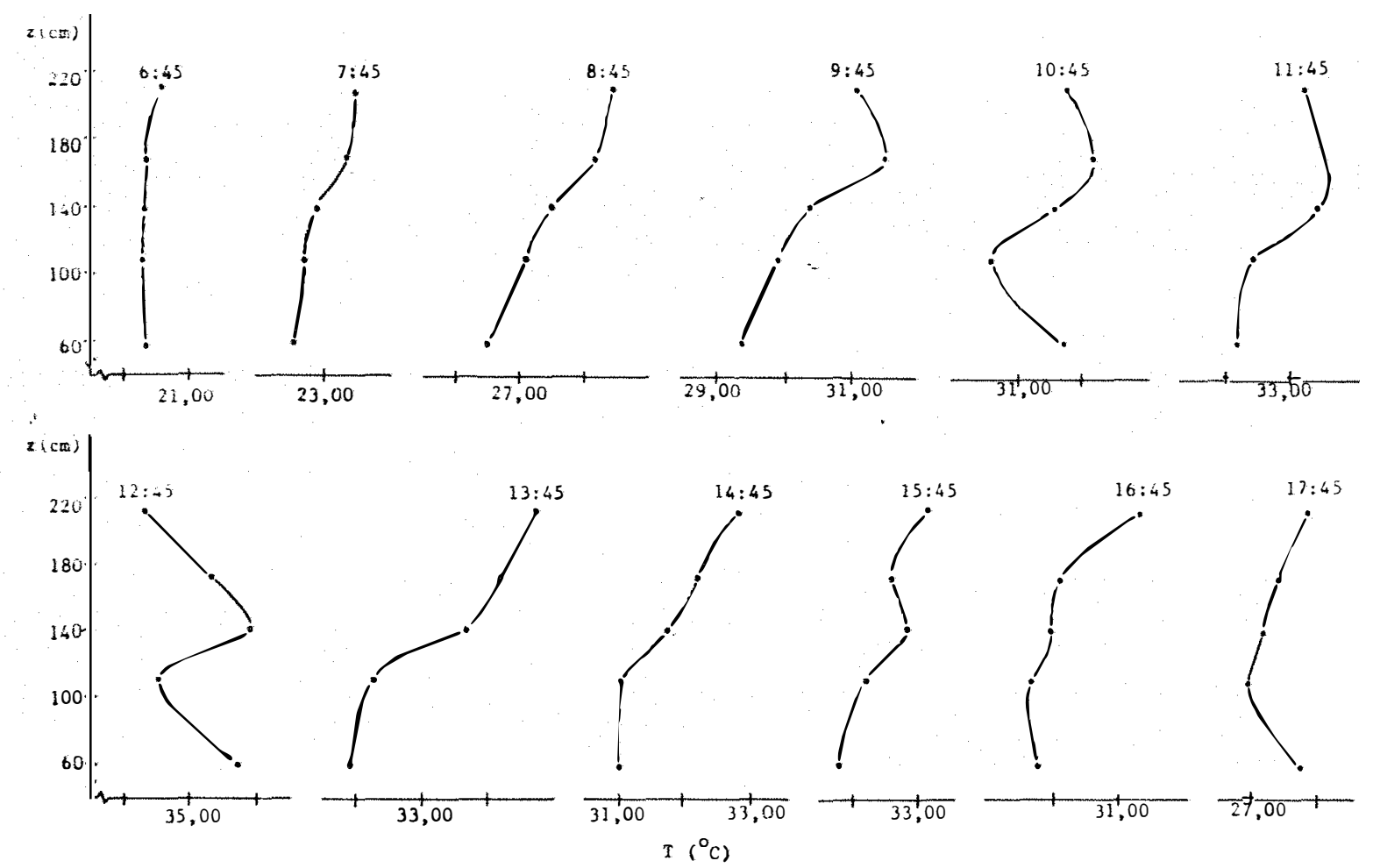

(a)
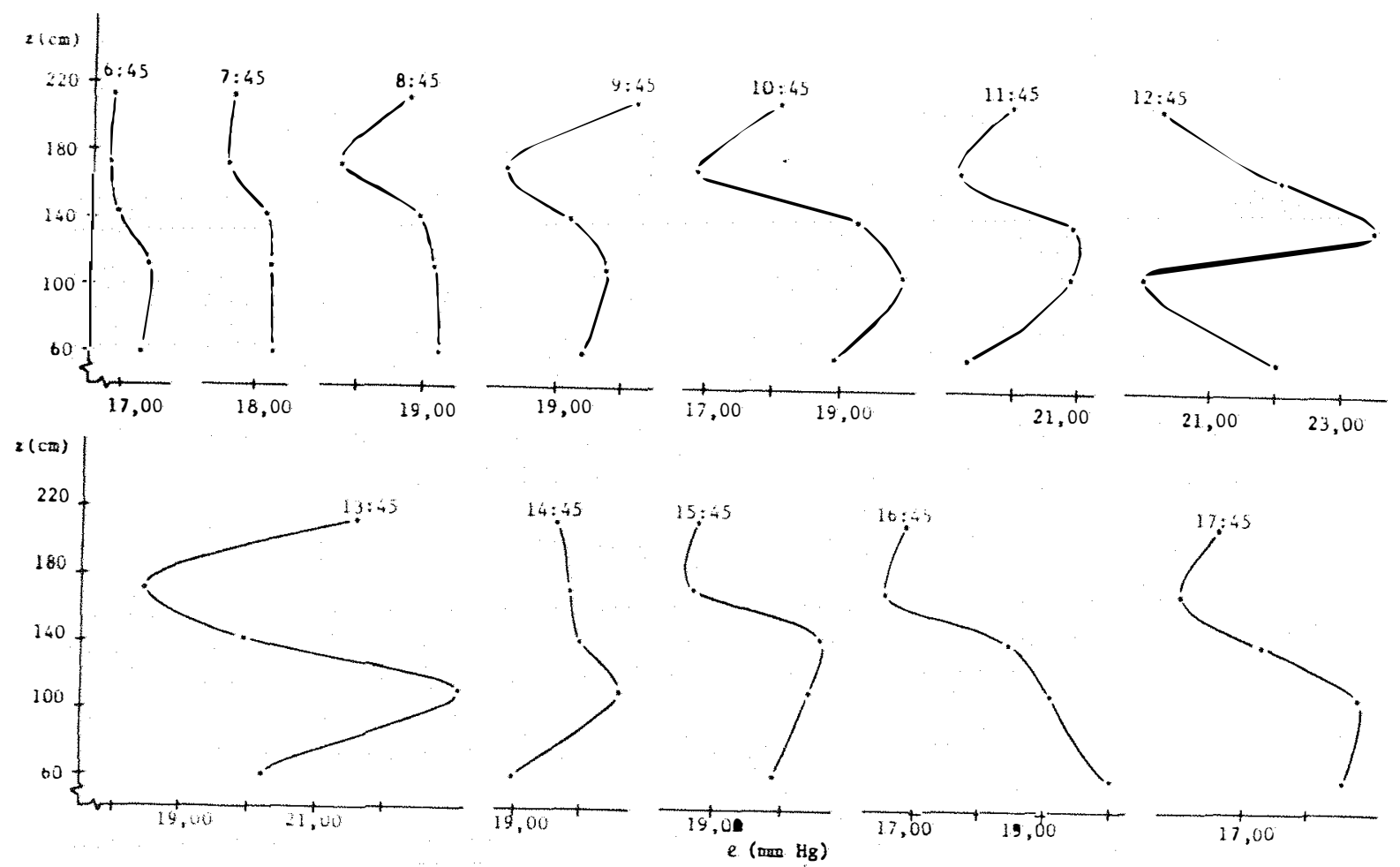

(b)

Figura 3 - Perfis de (a) temperatura e (b) tensão de vapor d'água no interior da cultura para diferentes tempos. (Tratamento 2). 

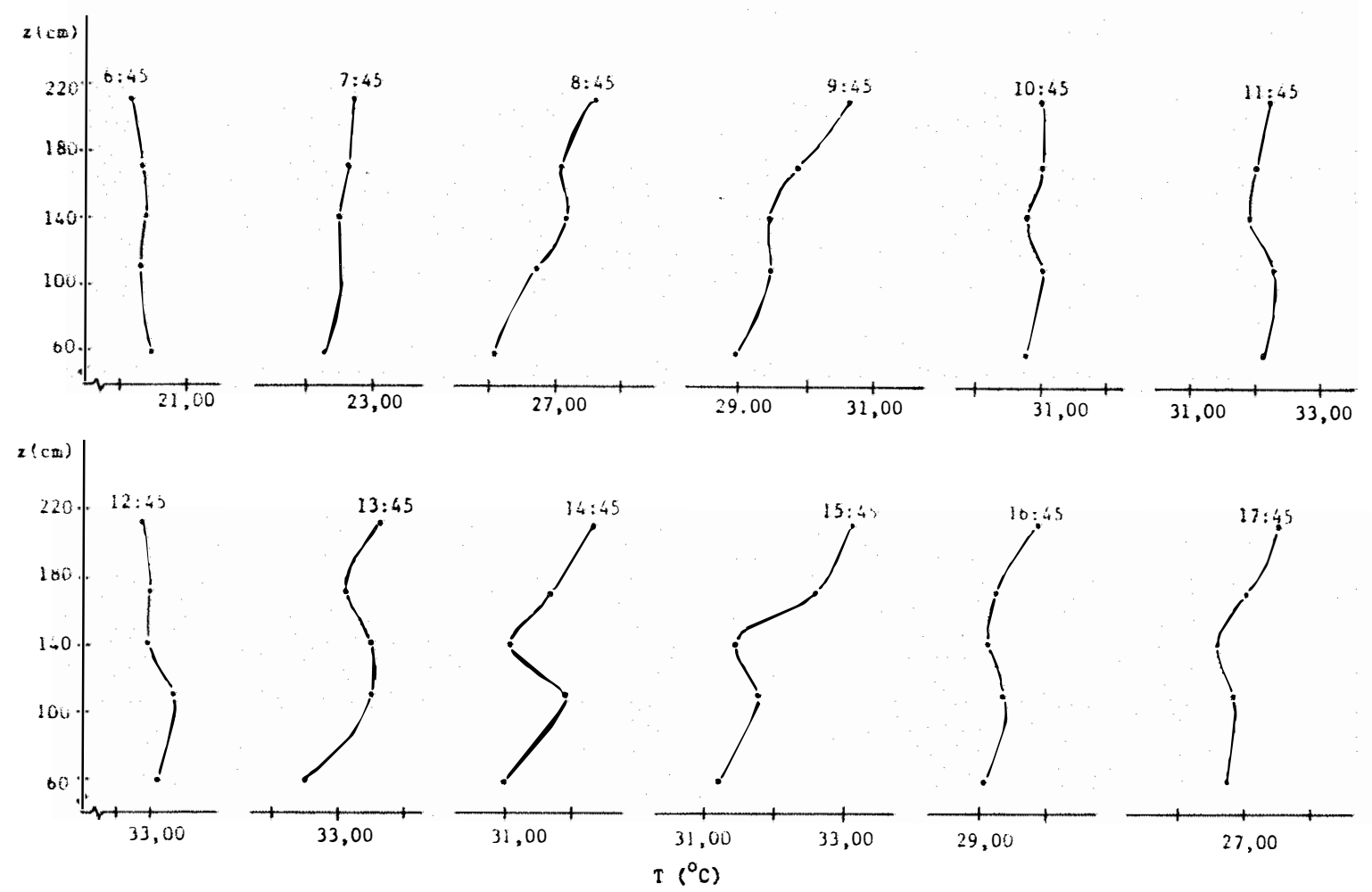

(a)
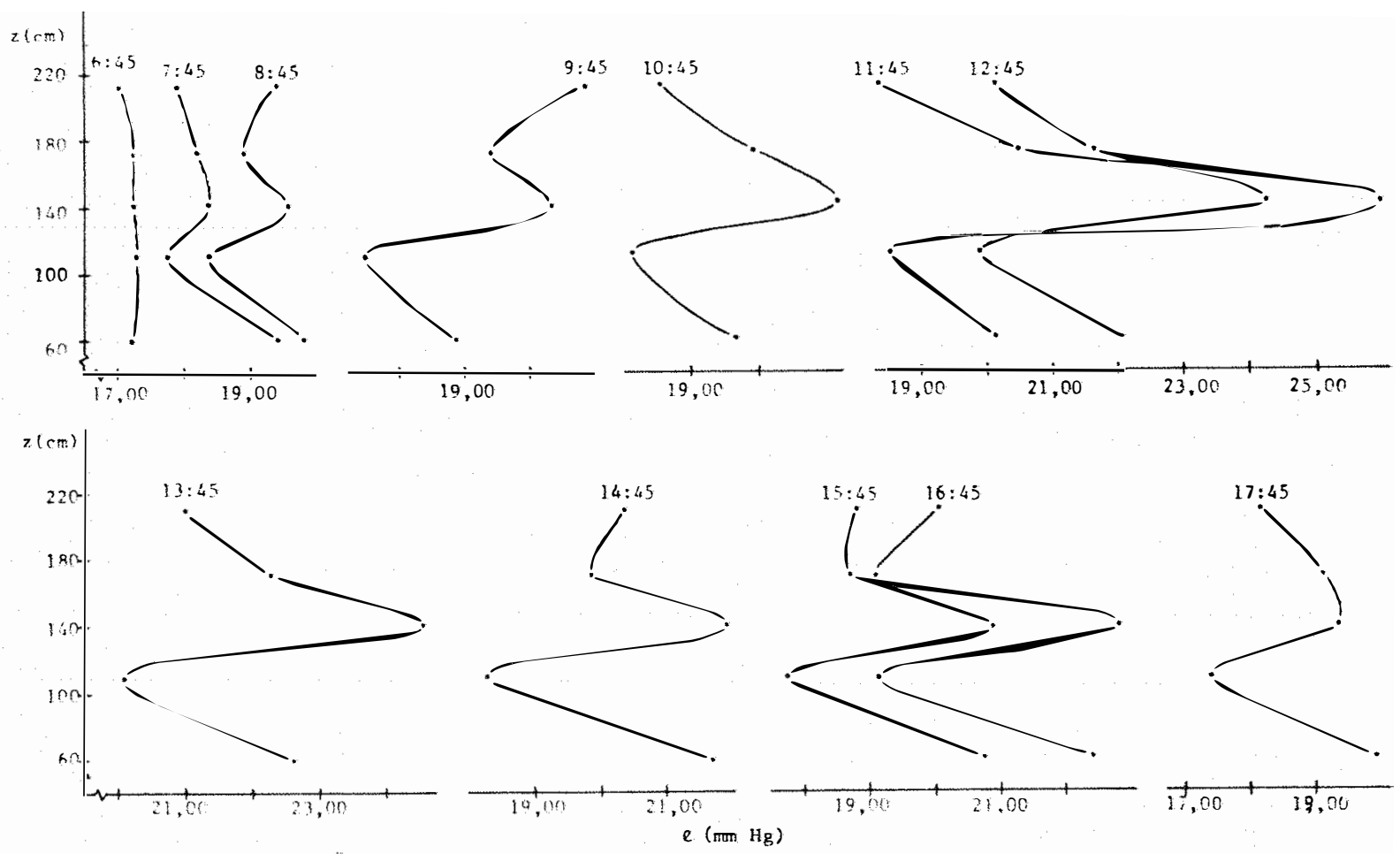

(b)

Figura 4 - Perfis de (a) temperatura e (b) tensão de vapor d'ägua no interior da cultura para diferentes tempos. (Tratamento 3). 
5.2. Fluxos de calor sensível e calor latente no interior da cultura

Tem-se na tabela 13 a distribuição vertical do coeficiente de transporte (K) no interior da cultura. Estes valores foram determinados a partir da equação 6 , respeitando os devidos limites de validade, já discutidos anteriormente. A representação gráfica destes valores para as diferentes alturas (z), isto é, o perfil de $K$, está apresentada na figura 5 .

Tabela 13. Valores do coeficiente de transporte (K) determinados a partir da equação 6 , para diferentes altu ras (z) no interior da cultura

\begin{tabular}{ll}
\hline$z(\mathrm{~cm})$ & $\mathrm{K}\left(\mathrm{cm}^{2}, \mathrm{~s}^{-}\right)$ \\
& \\
\hline 90 & 194,29 \\
100 & 199,76 \\
110 & 205,39 \\
120 & 211,17 \\
130 & 217,12 \\
140 & 223,24 \\
150 & 229,53 \\
160 & 235,99 \\
170 & 242,64 \\
180 & 249,47 \\
190 & 256,50 \\
200 & 263,73 \\
210 & 271,25 \\
230 & 286,64 \\
250 & 303,02 \\
270 & 320,33 \\
\hline
\end{tabular}




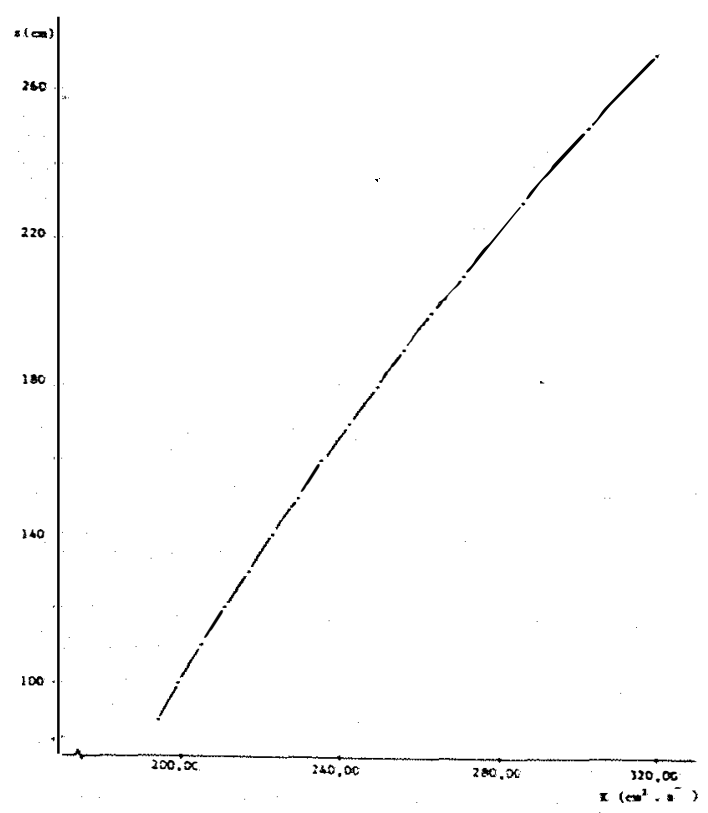

Figura 5 - Perfil do coeficiente de transporte (K) no interior da cultura

Utilizando-se dos perfis de temperatura e tensão de vapor d'água do ar, juntamente com o perfil do coefici ente de transporte, determinou-se os fluxos de calor sensível e calor latente na seguinte região do interior da cultura, $90 \leqslant z \leqslant 190 \mathrm{~cm}$. Nas tabelas 14 a 16 e figuras 6 a 11 estãore presentados os fluxos referentes aos perfis apresentados nas figuras 2 a 4 .

Visando observar o comportamento dos fluxos de calor sensível e calor latente ao longo do dia em diferentes camadas da cultura representou-se graficamente a variação dos fluxos no interior da cultura com o tempo para as seguintes ca madas: $90,110,130,150,170$ e $190 \mathrm{~cm}$. (Figuras 12 a 17). 


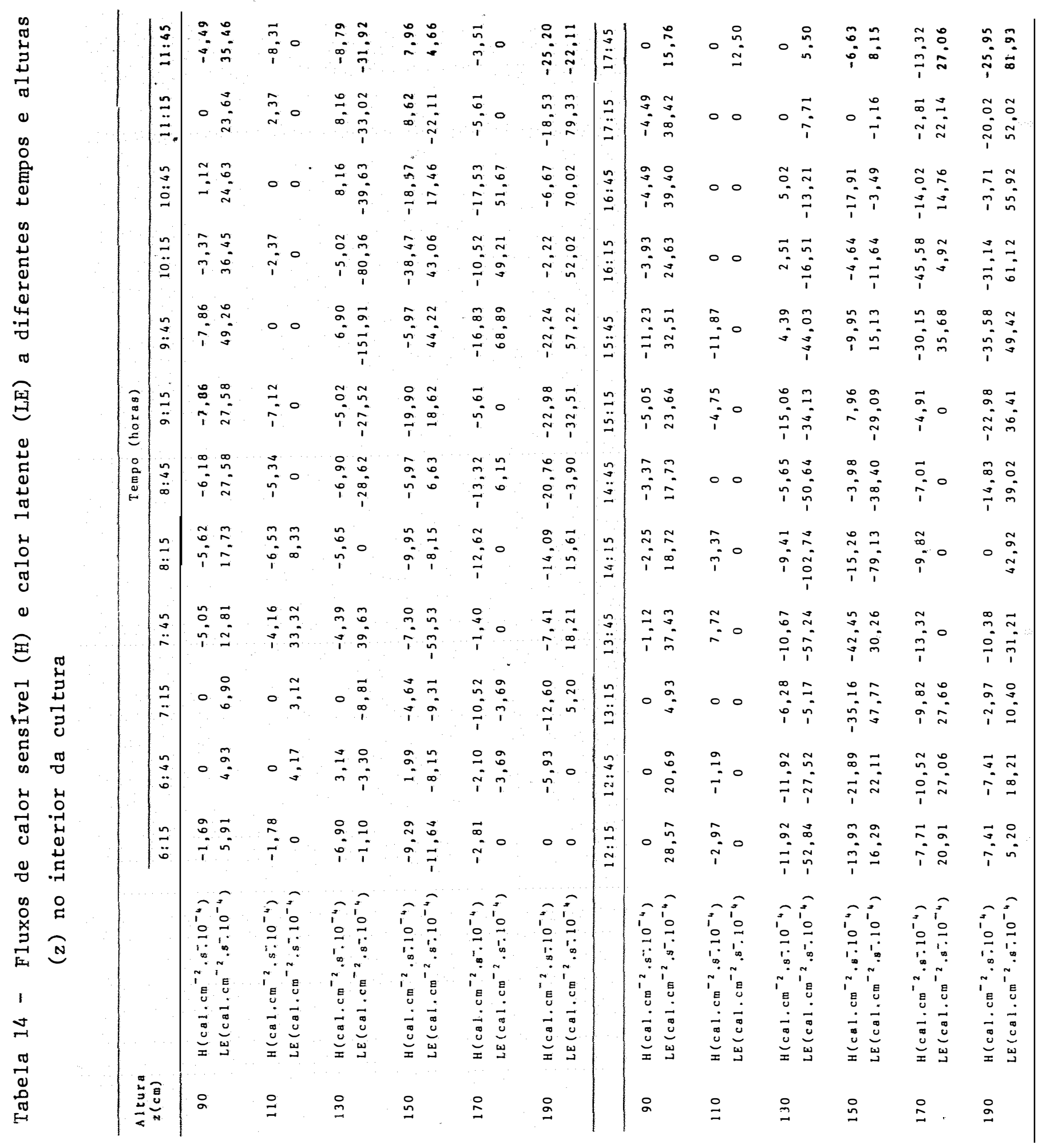




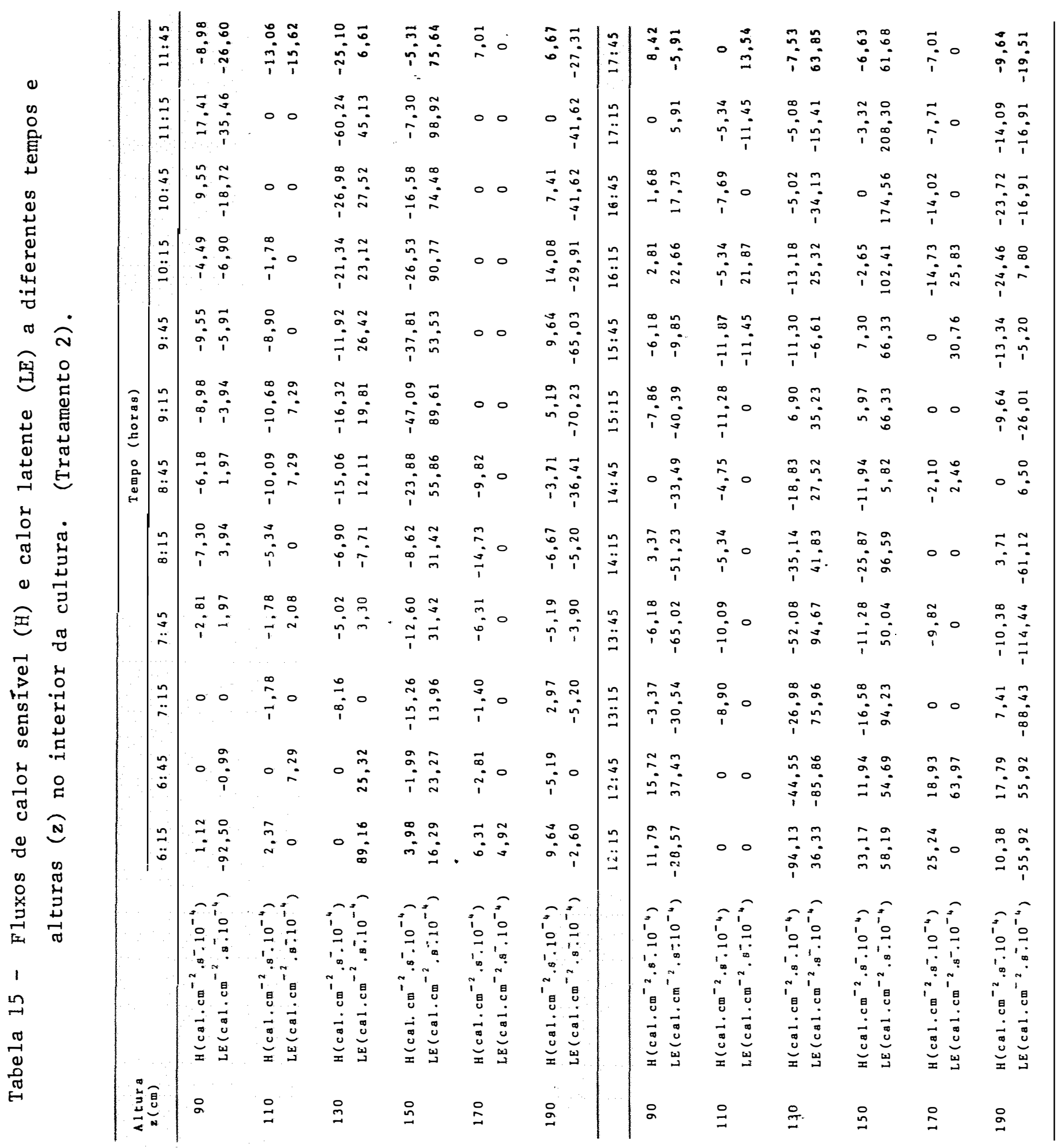




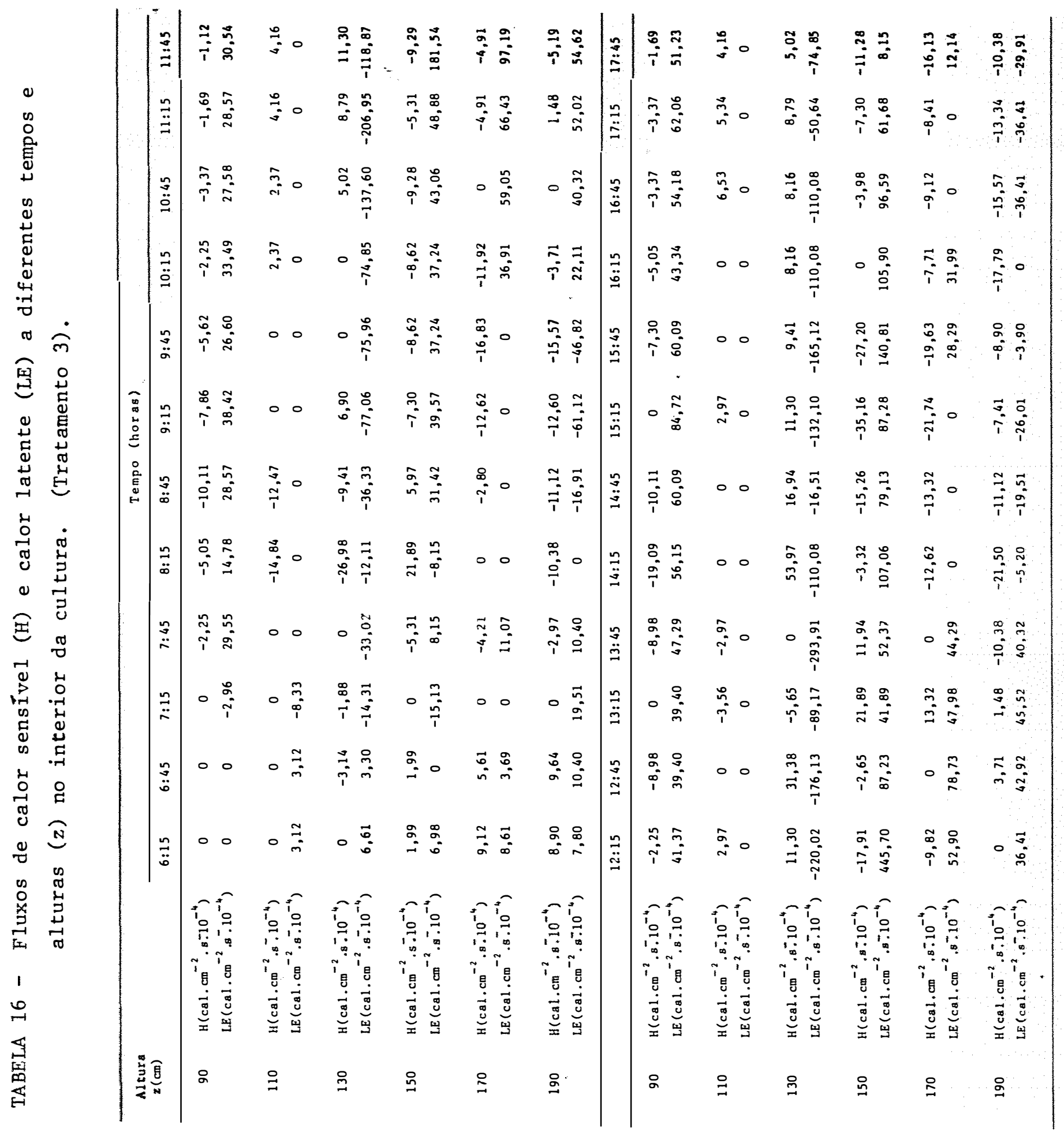




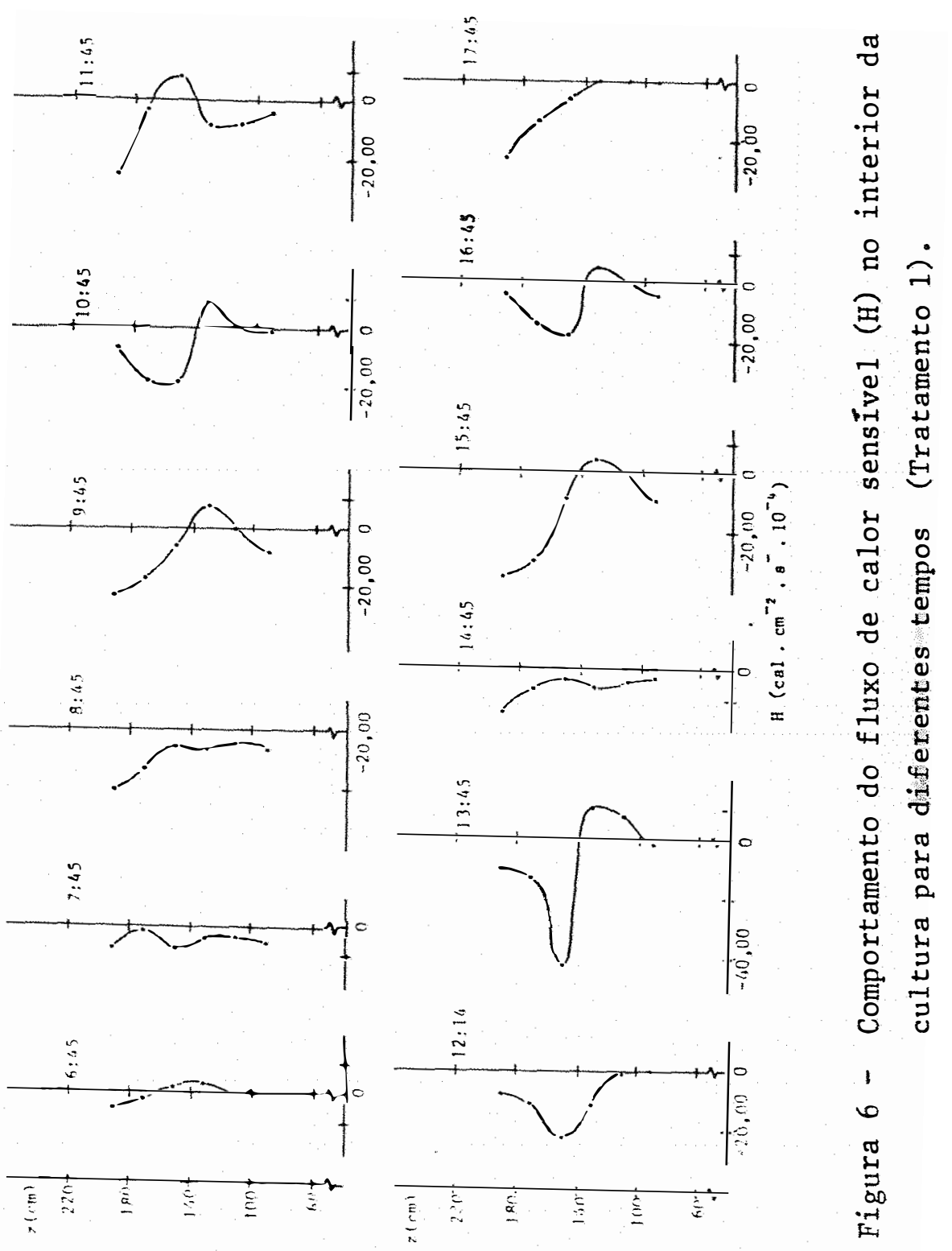




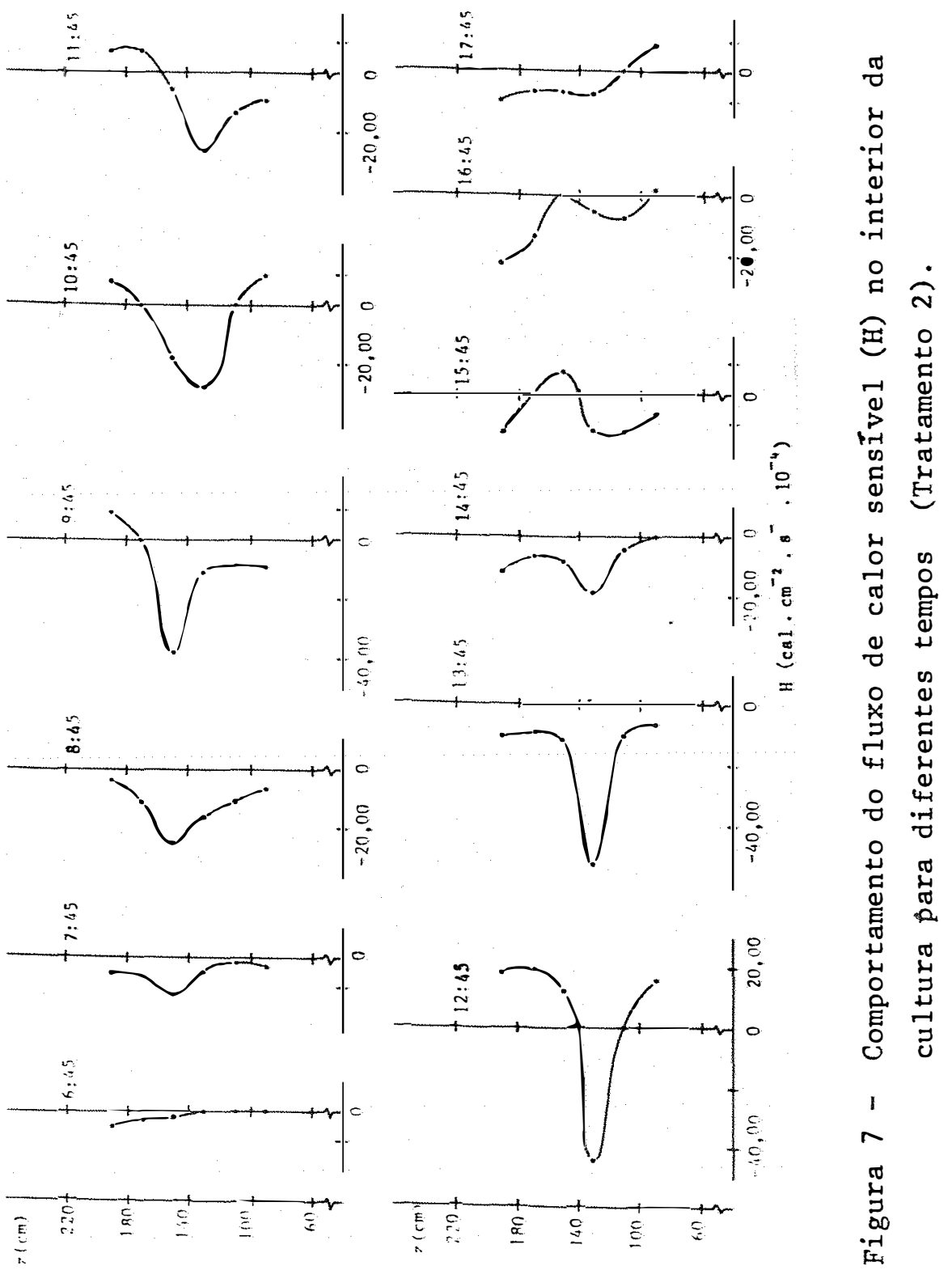




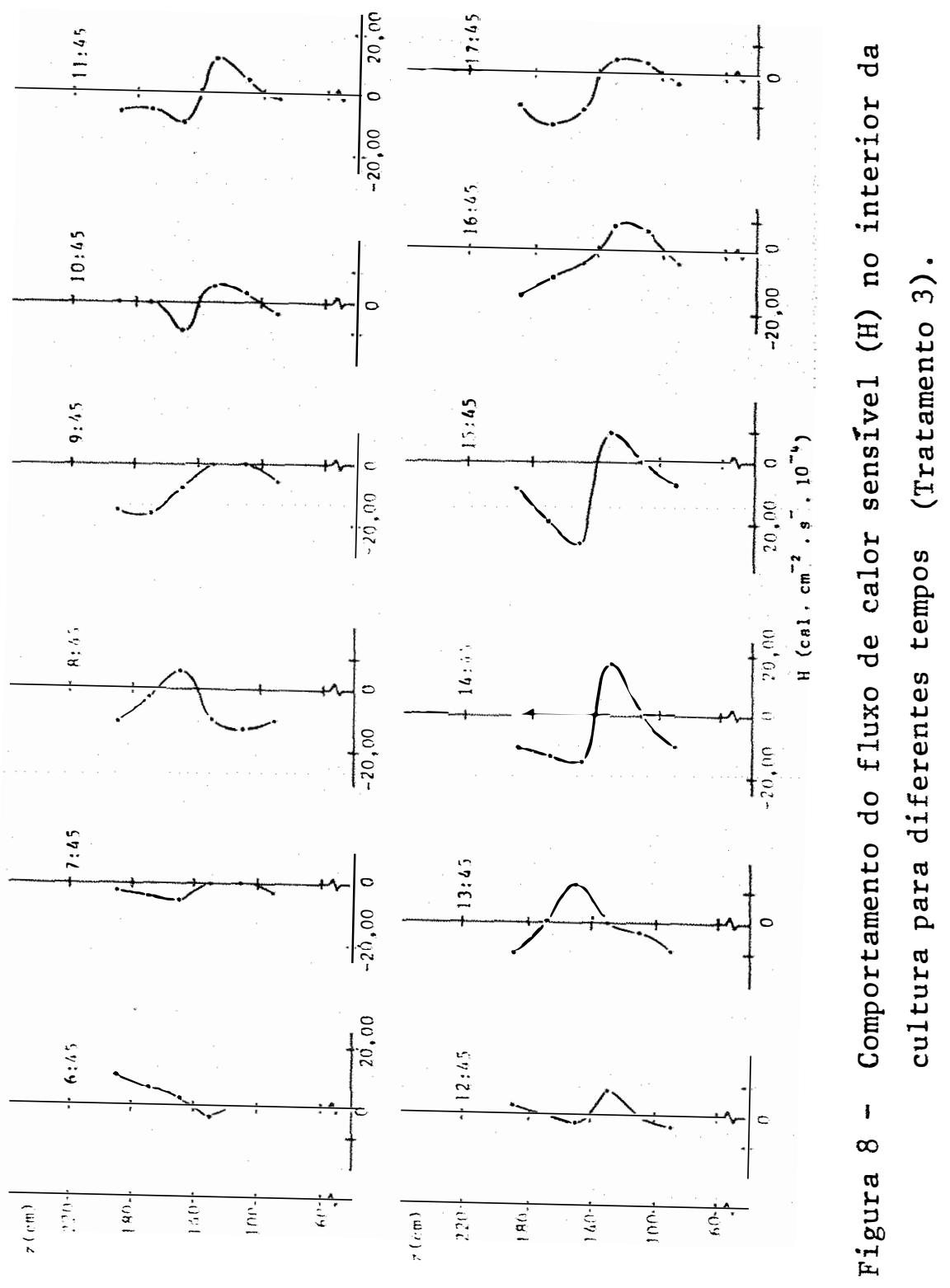




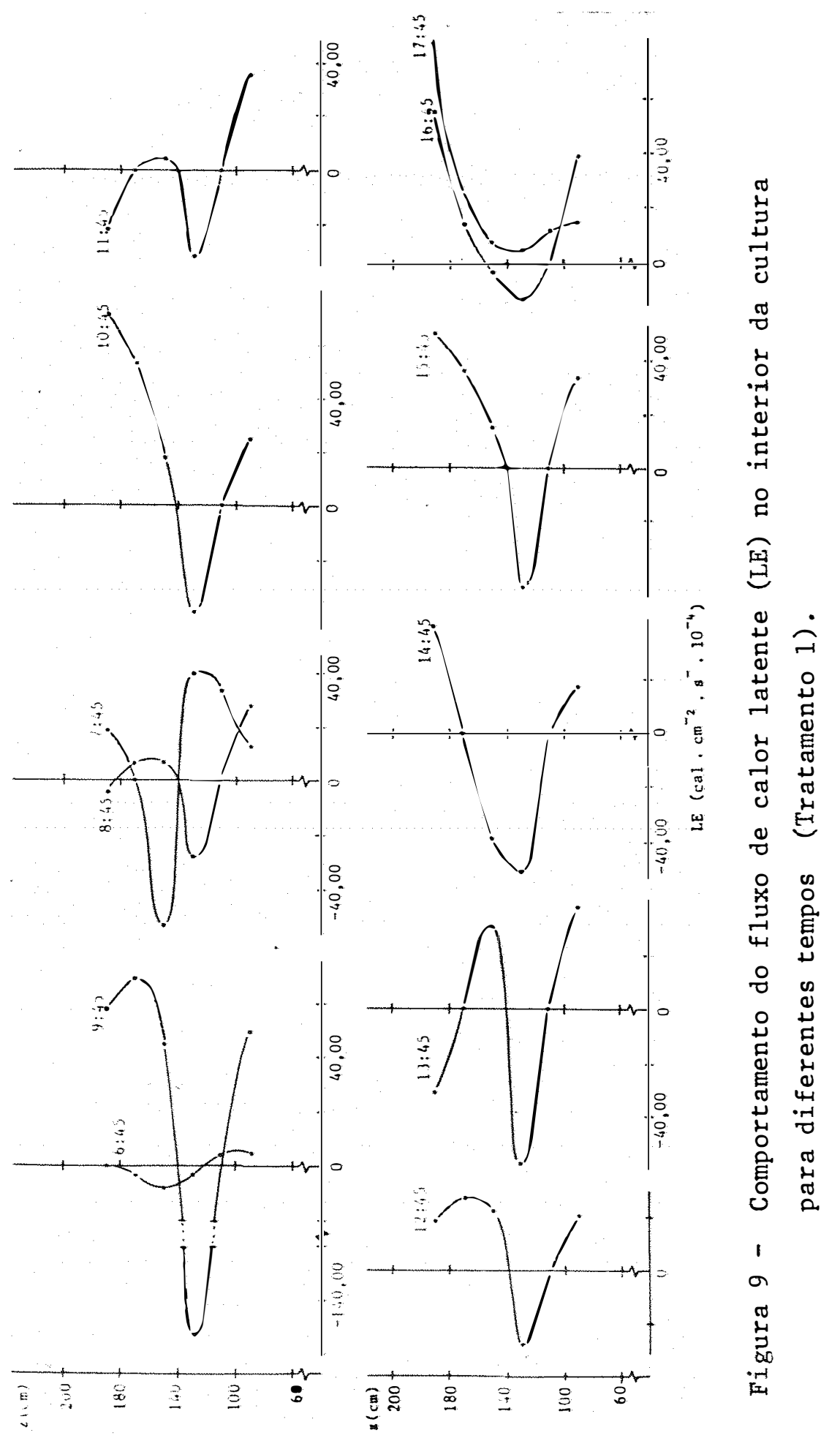



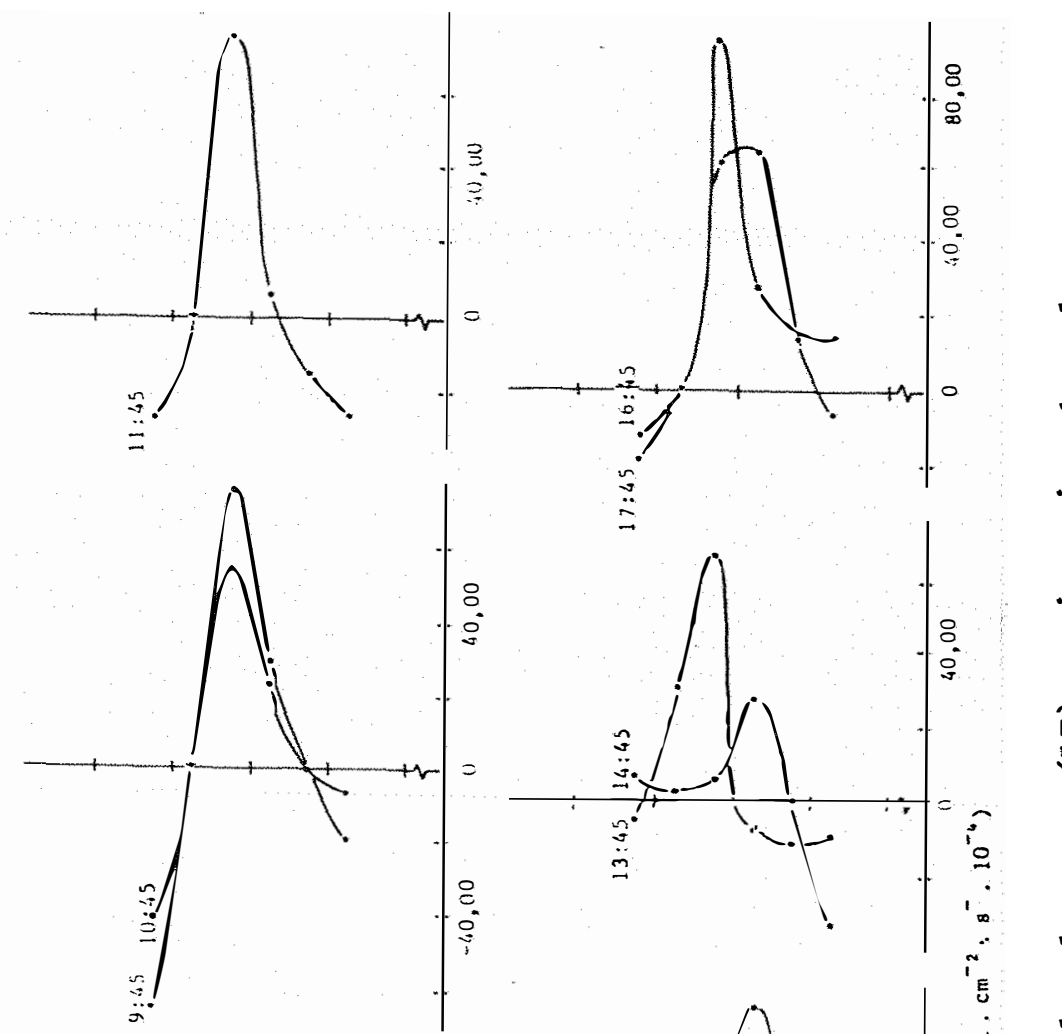

㫕 ग 옴

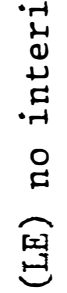

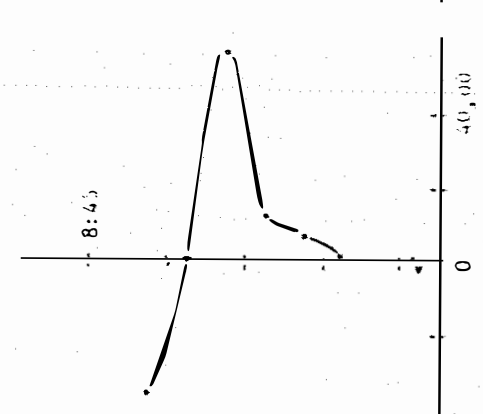

0
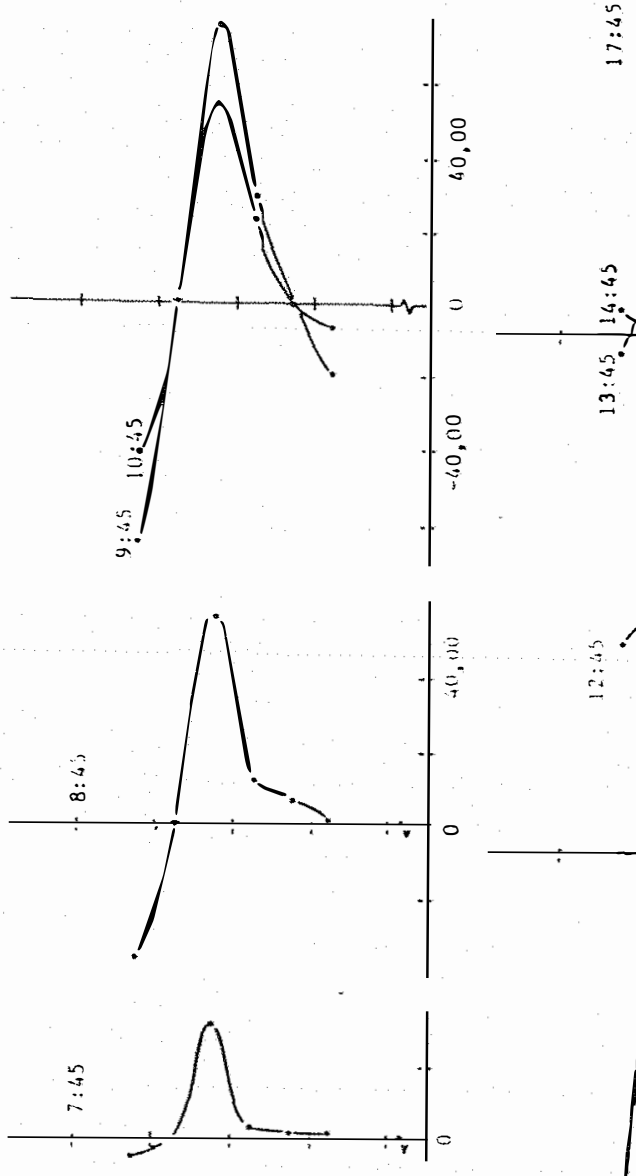

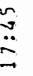
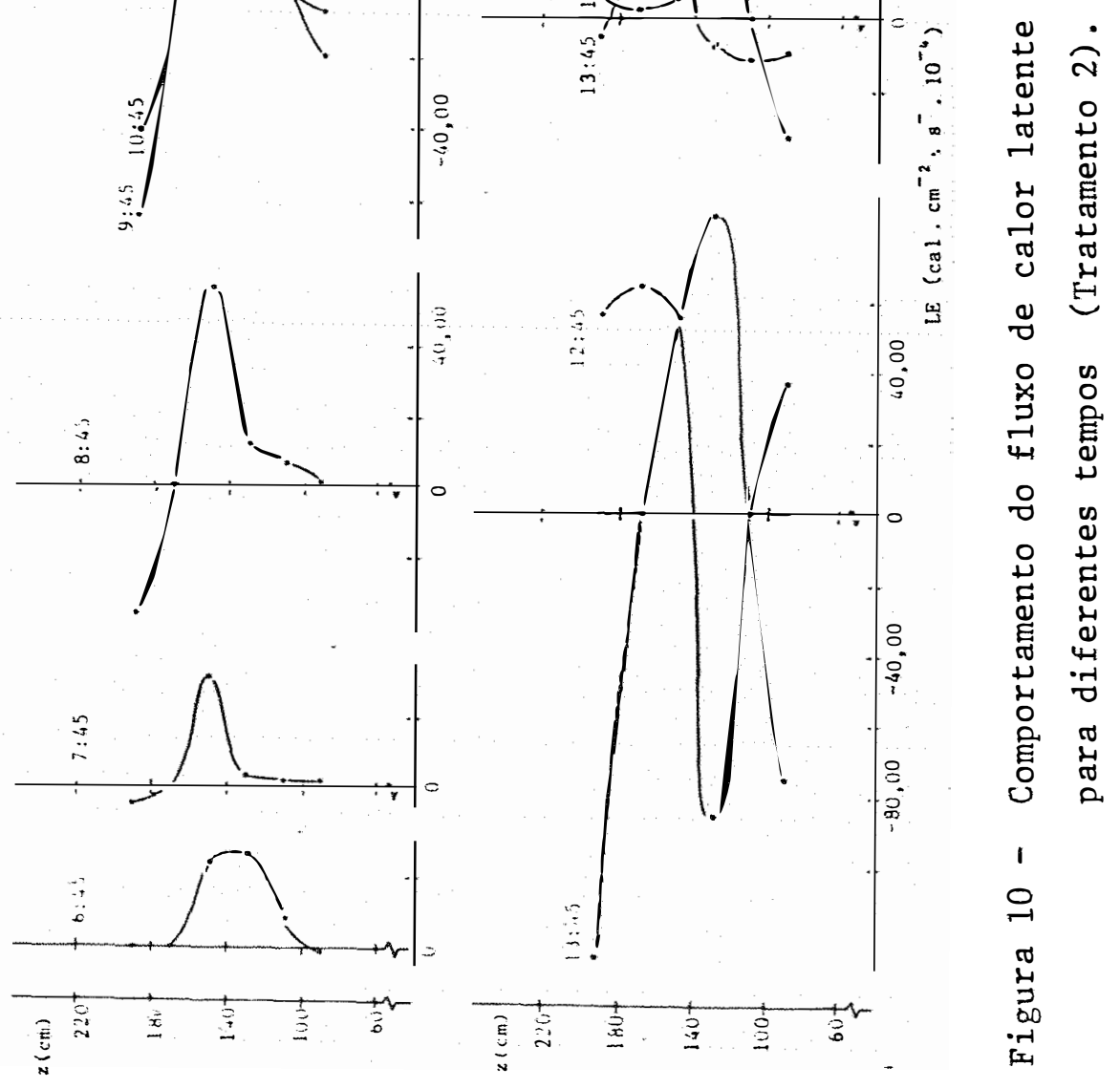

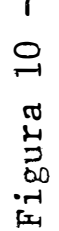




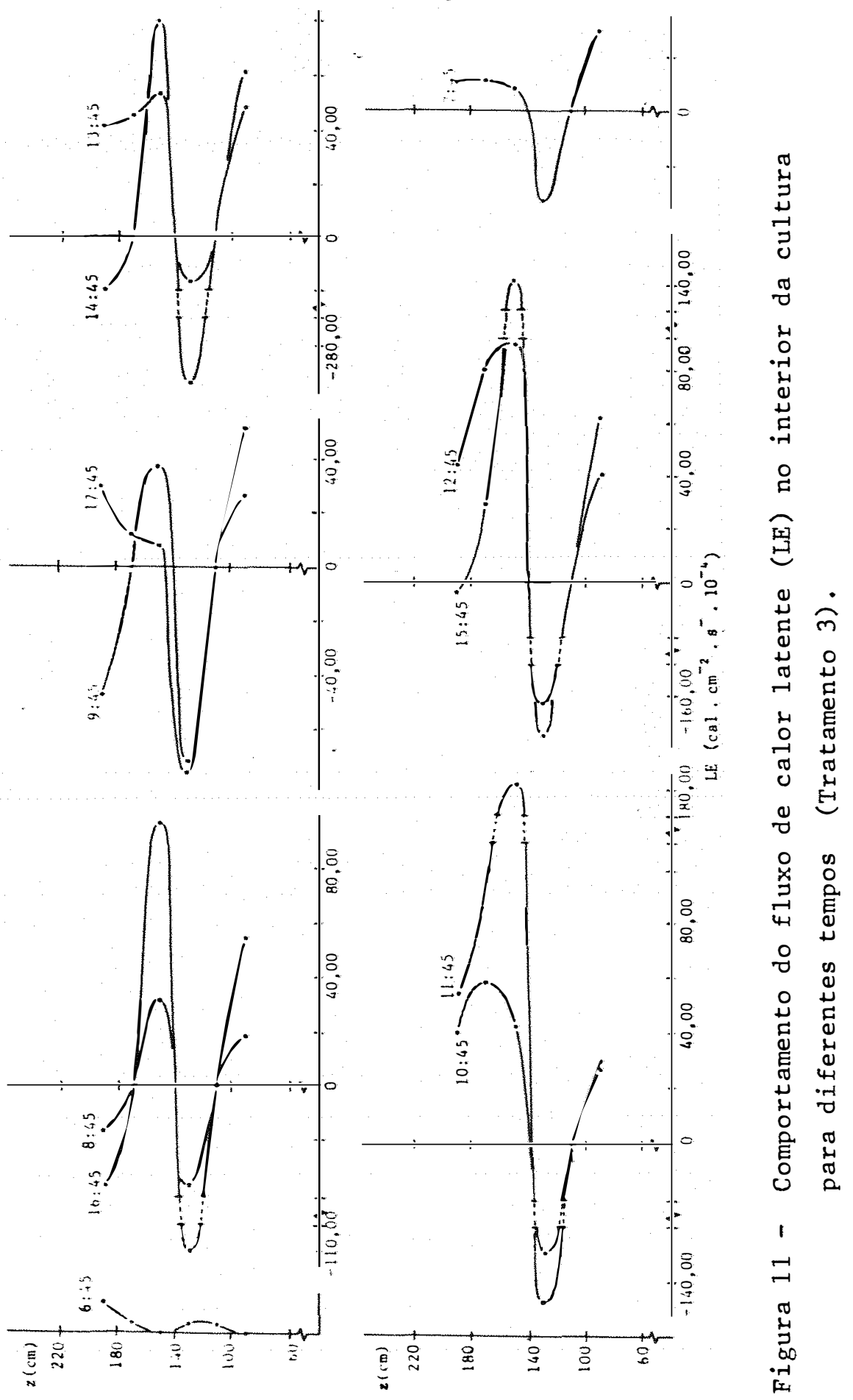




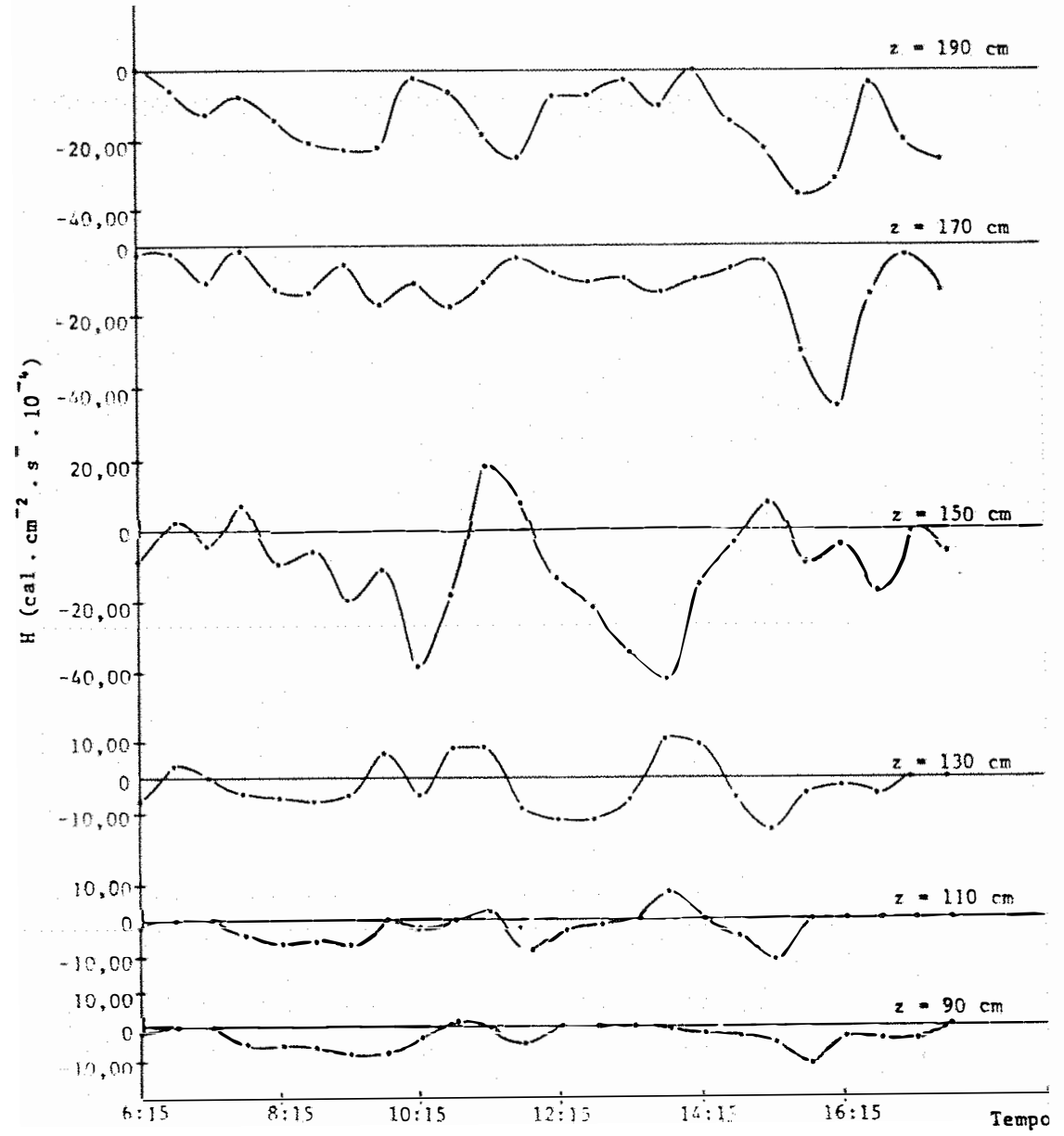

Figura 12 - Variação diāria do fluxo de calor sensível (H) em diferentes camadas da cultura (Tratamento 1) 


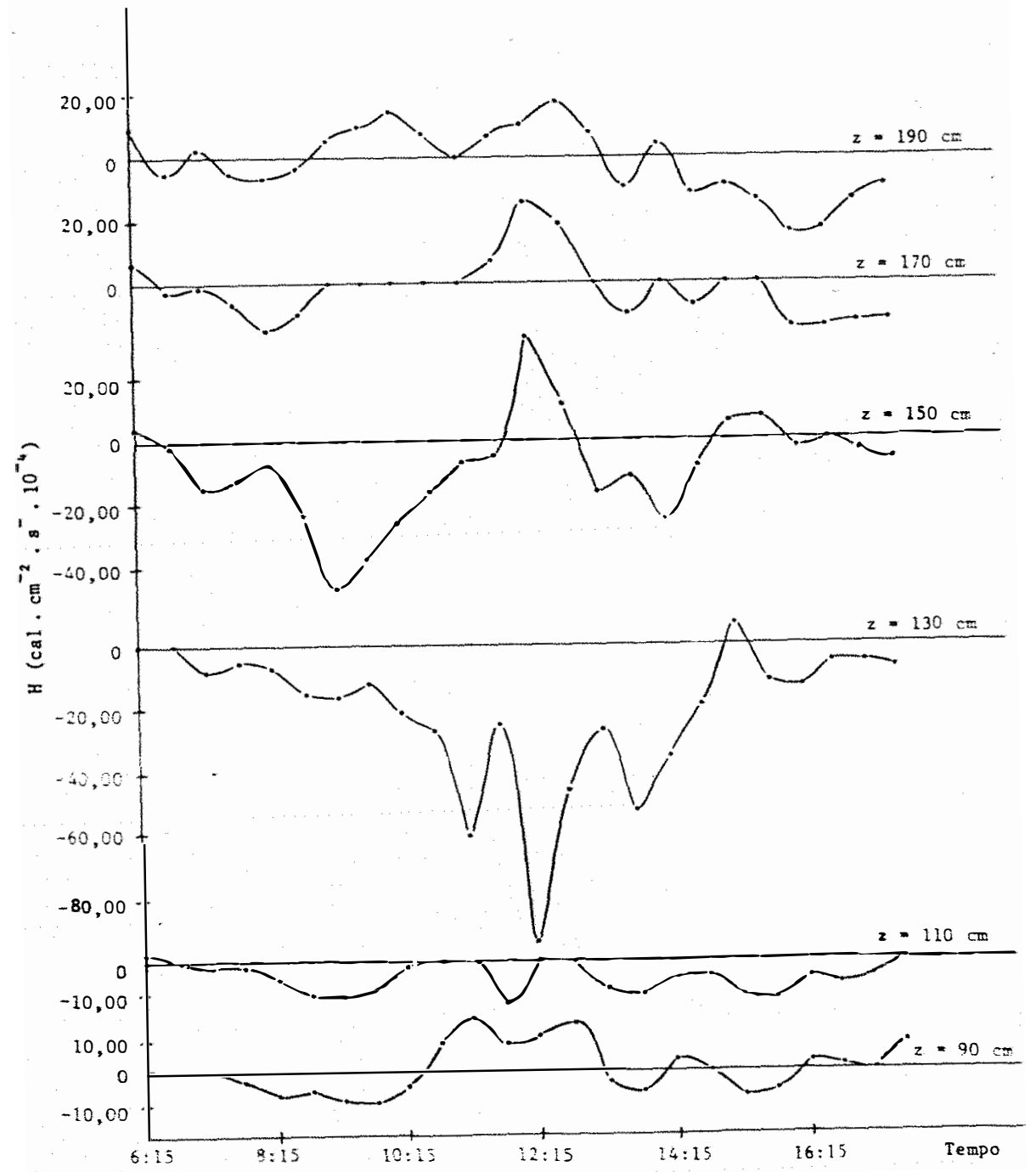

Figura 13 - Variação diäria do fluxo de calor sensível (H) em diferentes camadas da cultura (Tratamento 2) 


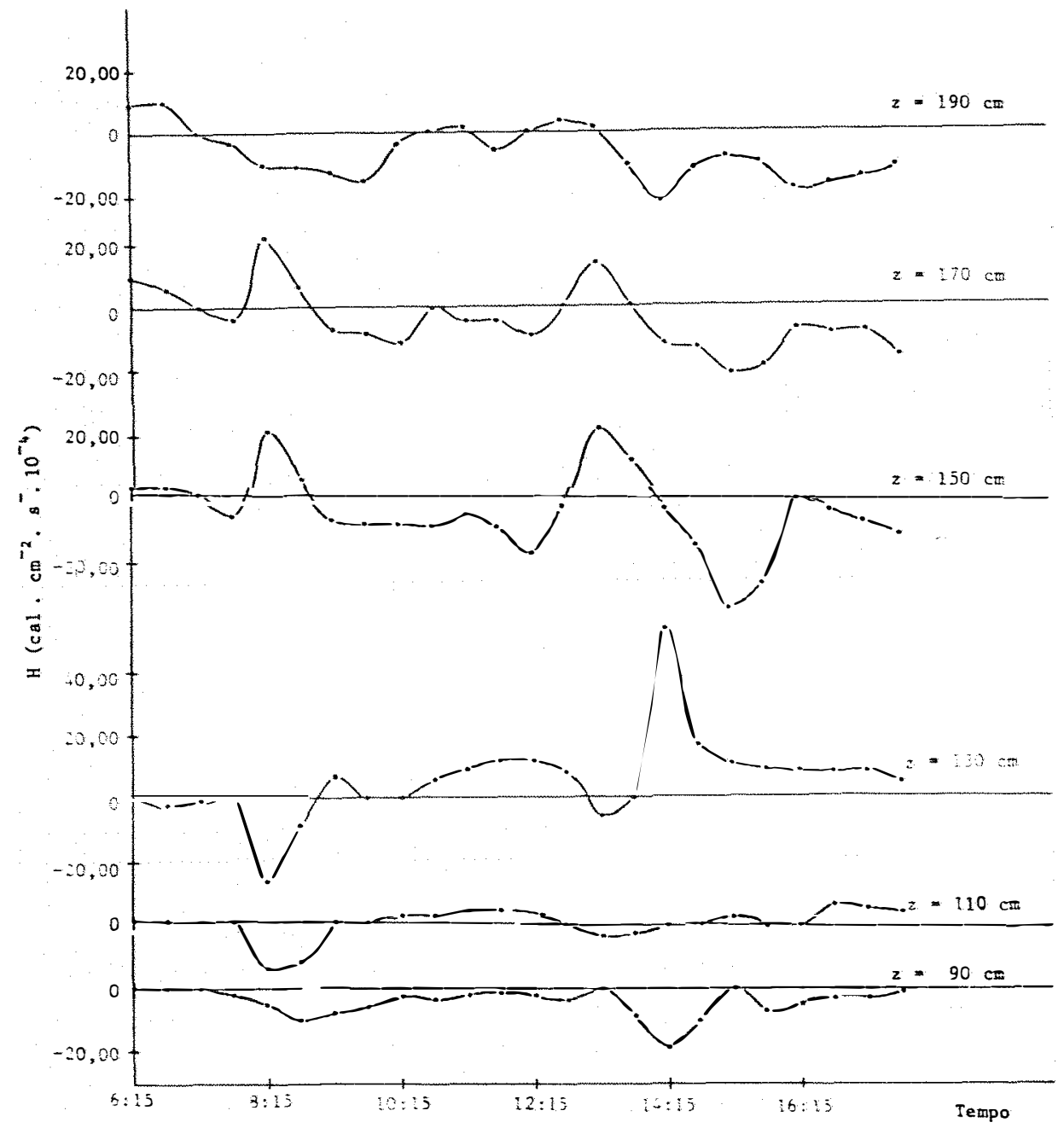

Figura 14 - Variação diária do fluxo de calor sensível (H) em diferentes camadas da cultura (Tratamento 3) 


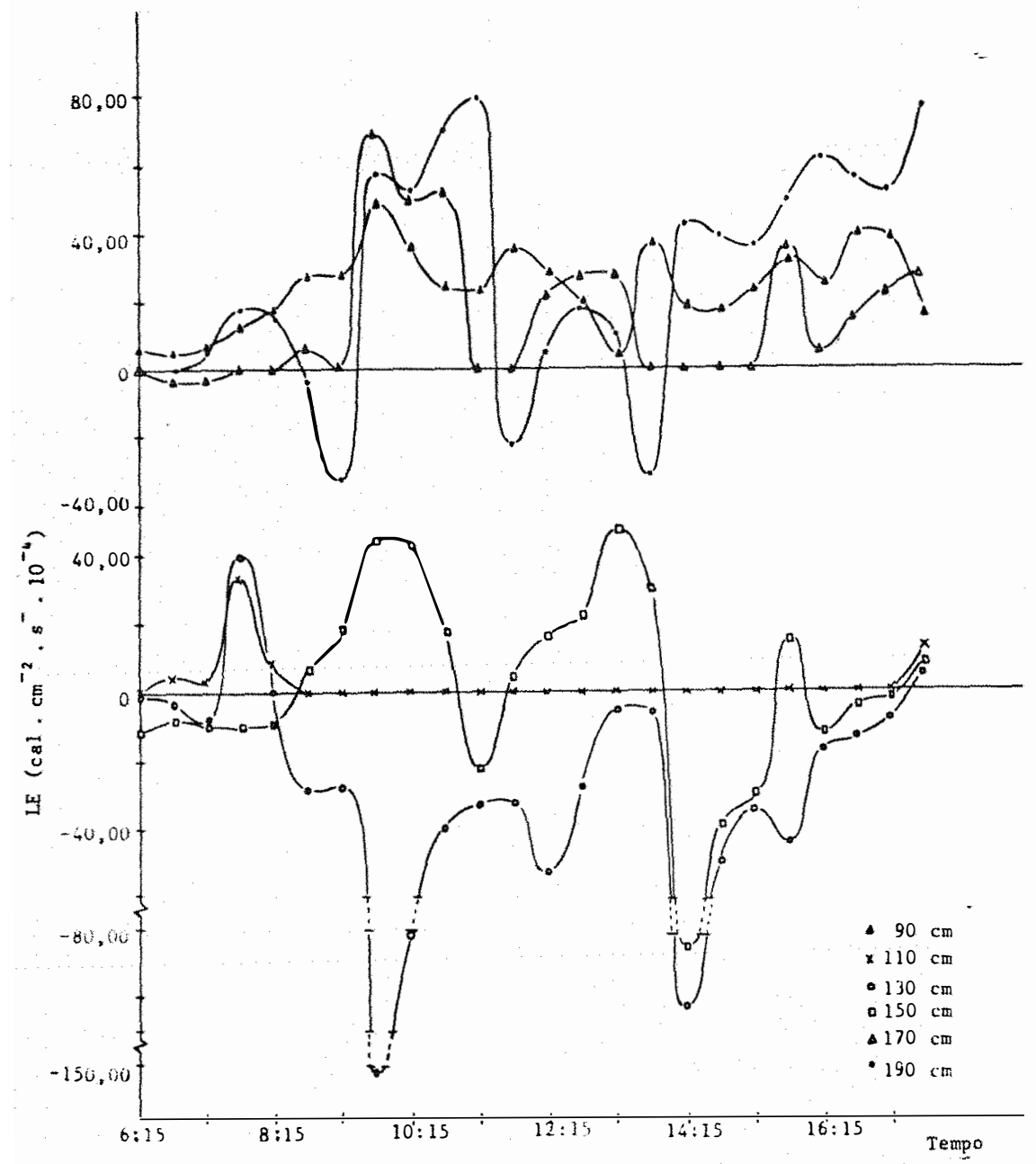

Figura 15 - Variação diāria do fluxo de calor latente (LE) em diferentes camadas da cultura (Tratamento 1 


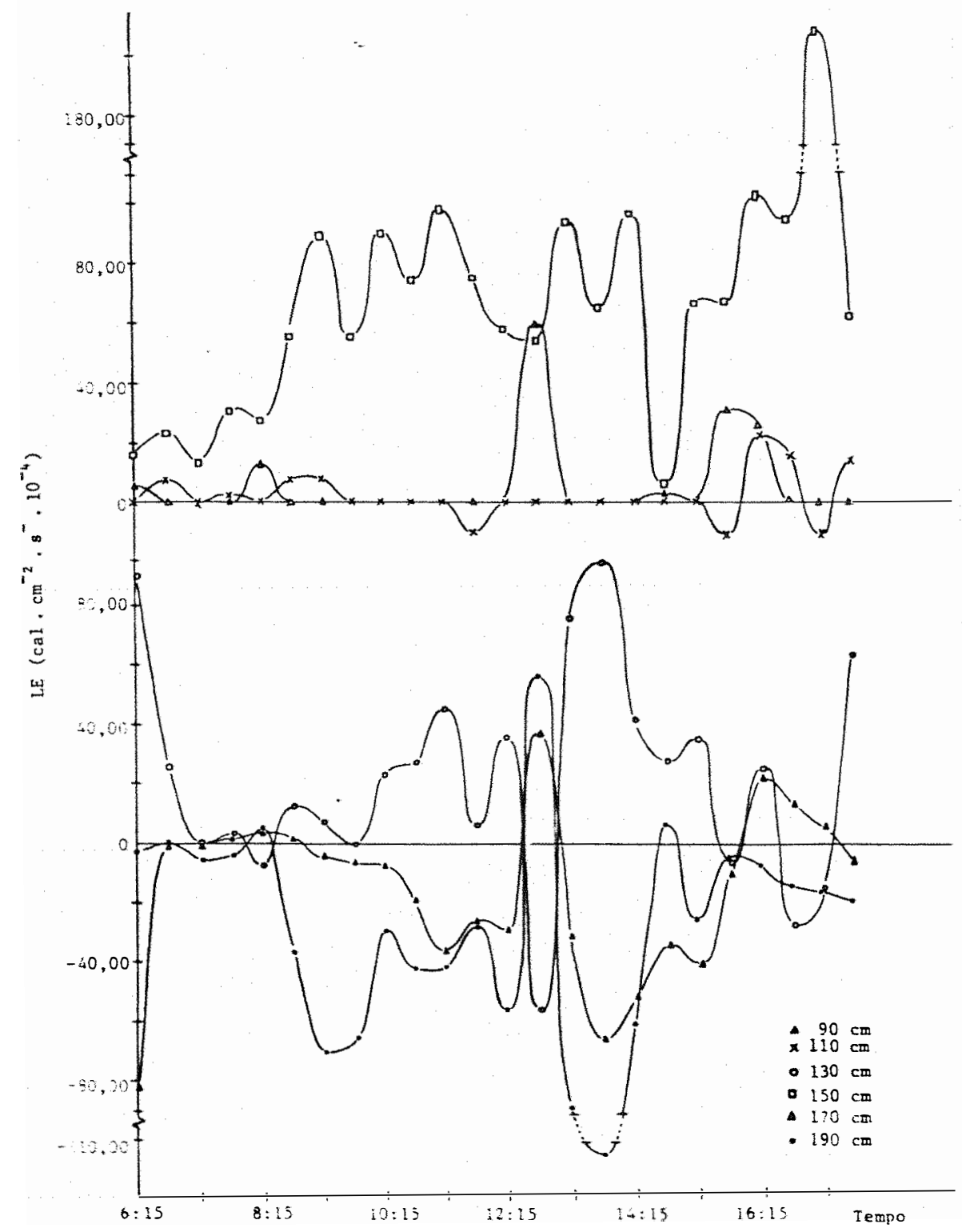

Figura 16 - Variação diária do fluxo de calor latente (LE) em diferentes camadas da cultura (Tratamento 2). 


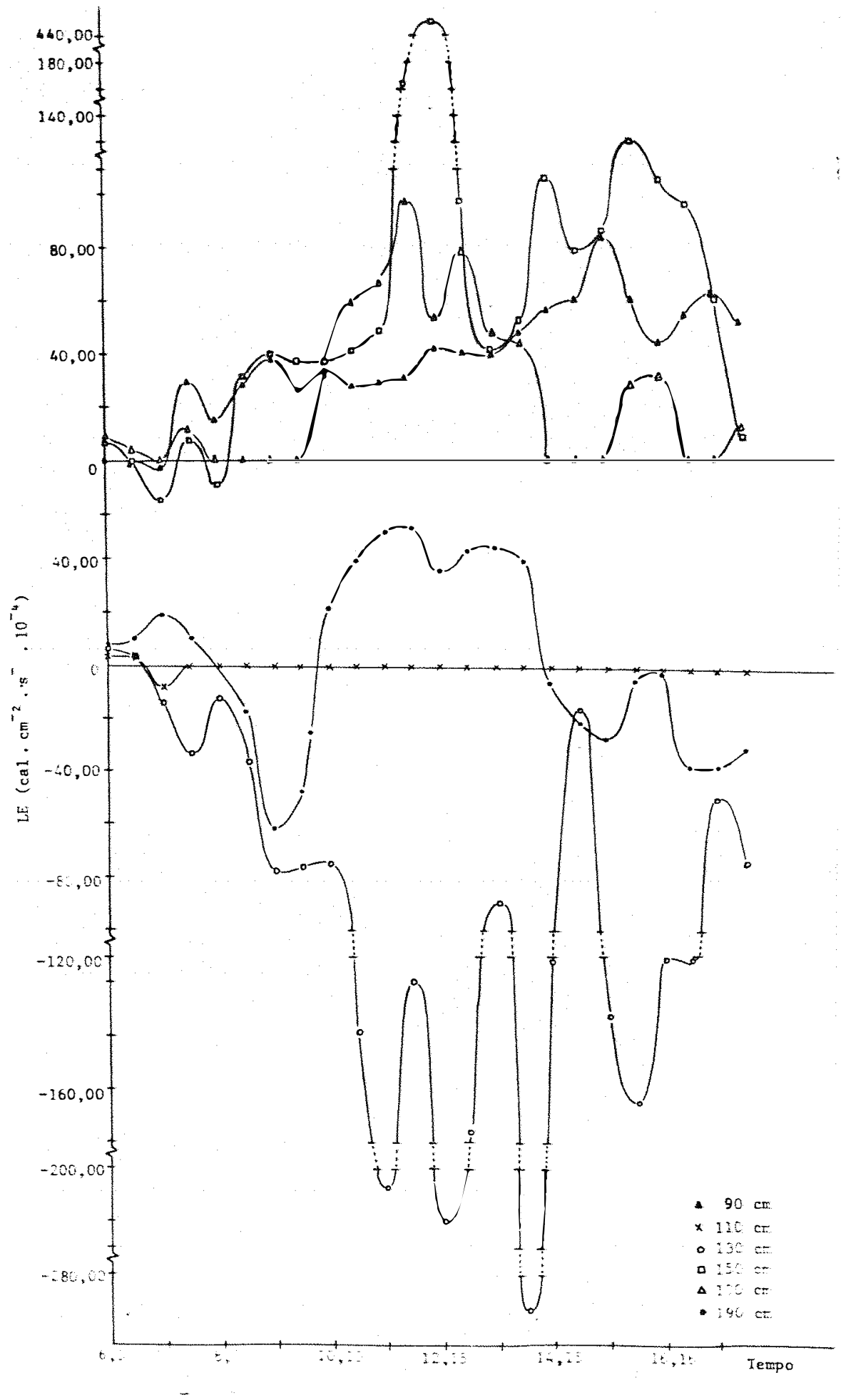

Figura 17 - Variação diāria do fluxo de calor latente (LE) em diferentes camadas da cultura (Tratamento 3). 
5.3. Distribuição vertical e as intensidades das fontes_e sorvedouros de calor sensível e calor latente.

Na tabela 17 tem-se os dados referentes aos gra dientes verticais de calor sensível e calor latente, que correspondem às intensidades das fontes e sorvedouros, para o ho rário de 10:45 do dia 01/02/78 nos diferentes tratamentos estudados.

Tabela 17. Intensidade das fontes e sorvedouros de calor sen sível e calor latente para o horário de 10:45 do dia $01 / 02 / 78$

\begin{tabular}{|c|c|c|c|c|c|c|}
\hline \multirow[t]{2}{*}{$z(\mathrm{~cm})$} & \multicolumn{3}{|c|}{$\frac{\mathrm{dH}}{\mathrm{dz}}\left(\mathrm{cal} \cdot \mathrm{cm}^{-3} \cdot \mathrm{s}^{-} \cdot 10^{-6}\right)$} & \multicolumn{3}{|c|}{$\frac{\mathrm{dLE}}{\mathrm{dz}}\left(\mathrm{ca} 1 \cdot \mathrm{cm}^{-3} \cdot \mathrm{s}^{-} \cdot 10^{-6}\right)$} \\
\hline & $\mathrm{T}_{1}$ & $\mathrm{~T}_{2}$ & $\mathrm{~T}_{3}$ & $\mathrm{~T}_{1}$ & $\mathrm{~T}_{2}$ & $\mathrm{~T}_{3}$ \\
\hline 100 & 23,10 & $-44,21$ & 23,10 & $-126,62$ & 87,68 & $-115,86$ \\
\hline 120 & 32,45 & $-133,81$ & 16,54 & $-221,88$ & 132,20 & $-631,44$ \\
\hline 140 & $-81,00$ & 64,67 & $-109,66$ & 336,34 & 331,97 & 1052,41 \\
\hline 160 & 7,90 & 65,74 & 53,33 & 154,38 & $-585,66$ & 38,33 \\
\hline 180 & 53,37 & 37,73 & 0 & 92,29 & $-159,36$ & $-35,05$ \\
\hline
\end{tabular}

$T_{1}-$ Tratamento 1

$\mathrm{T}_{2}$ - Tratamento 2

T 3 - Tratamento 3

Nas figuras 18 a 20 pode-se observar os perfis de temperatura e tensão de vapor d'água do ar, os fluxos e a 
distribuição vertical de fontes e sorvedouros de calor sensivel e latente, juntamente com a intensidade destes. 


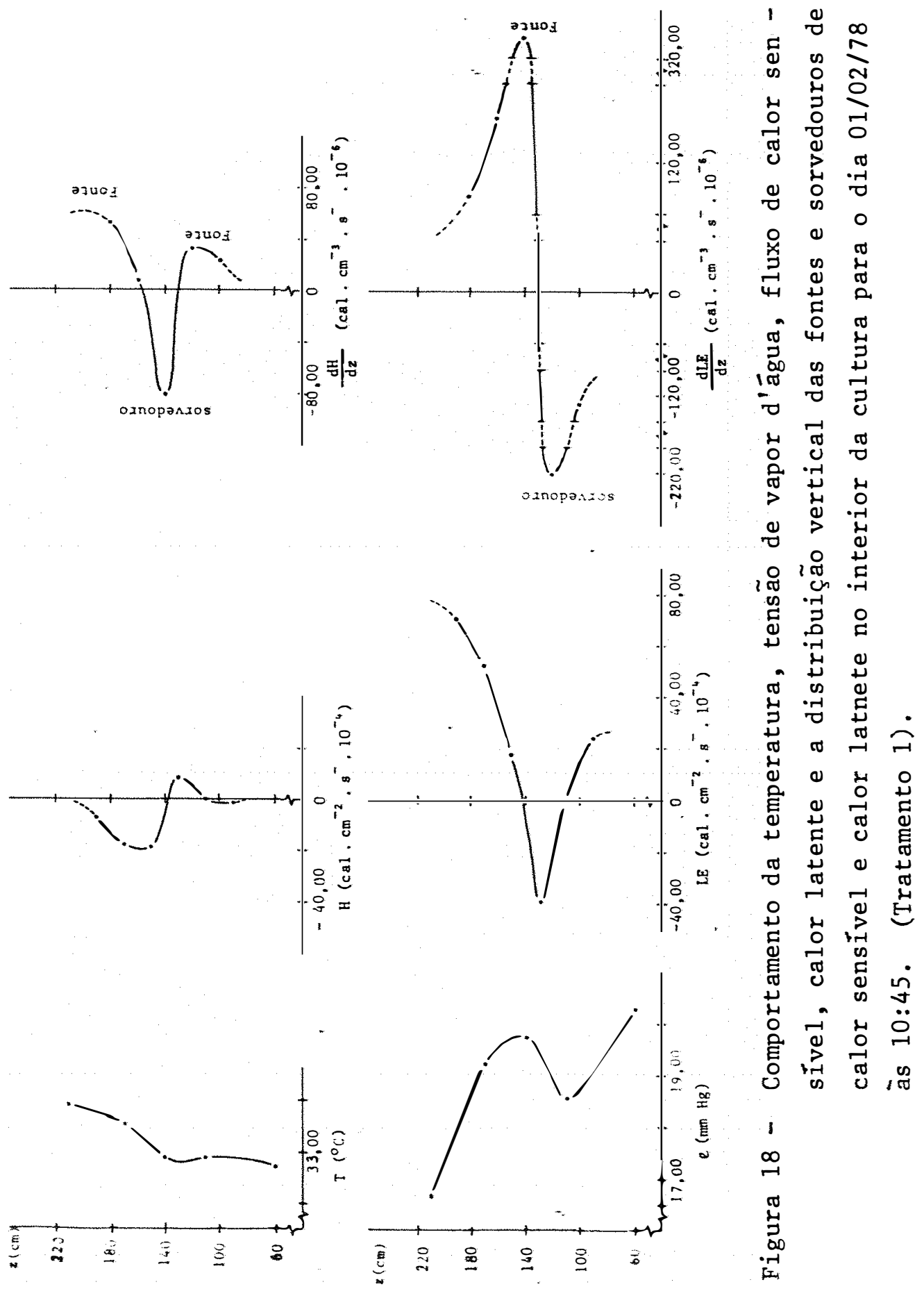




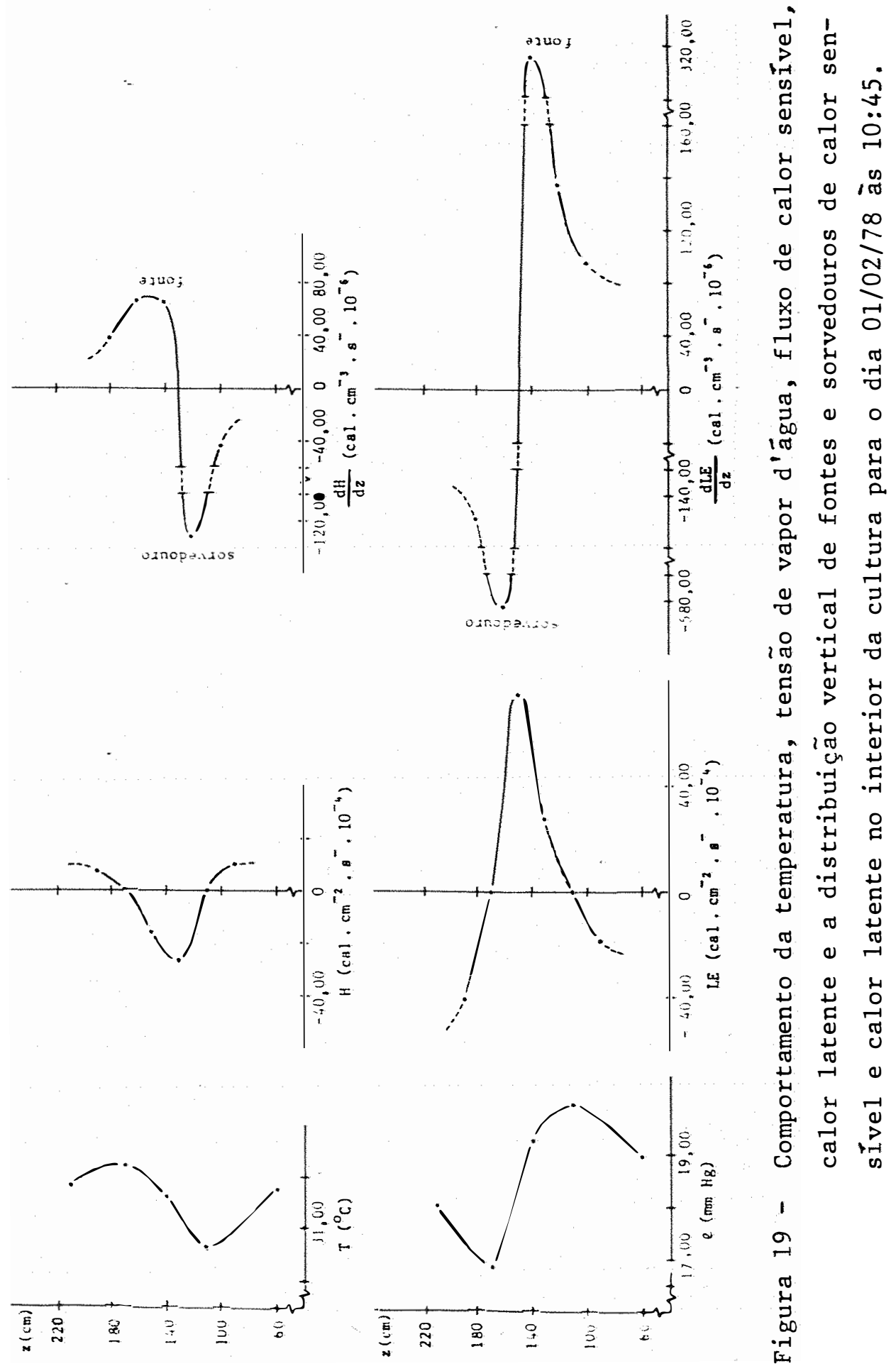




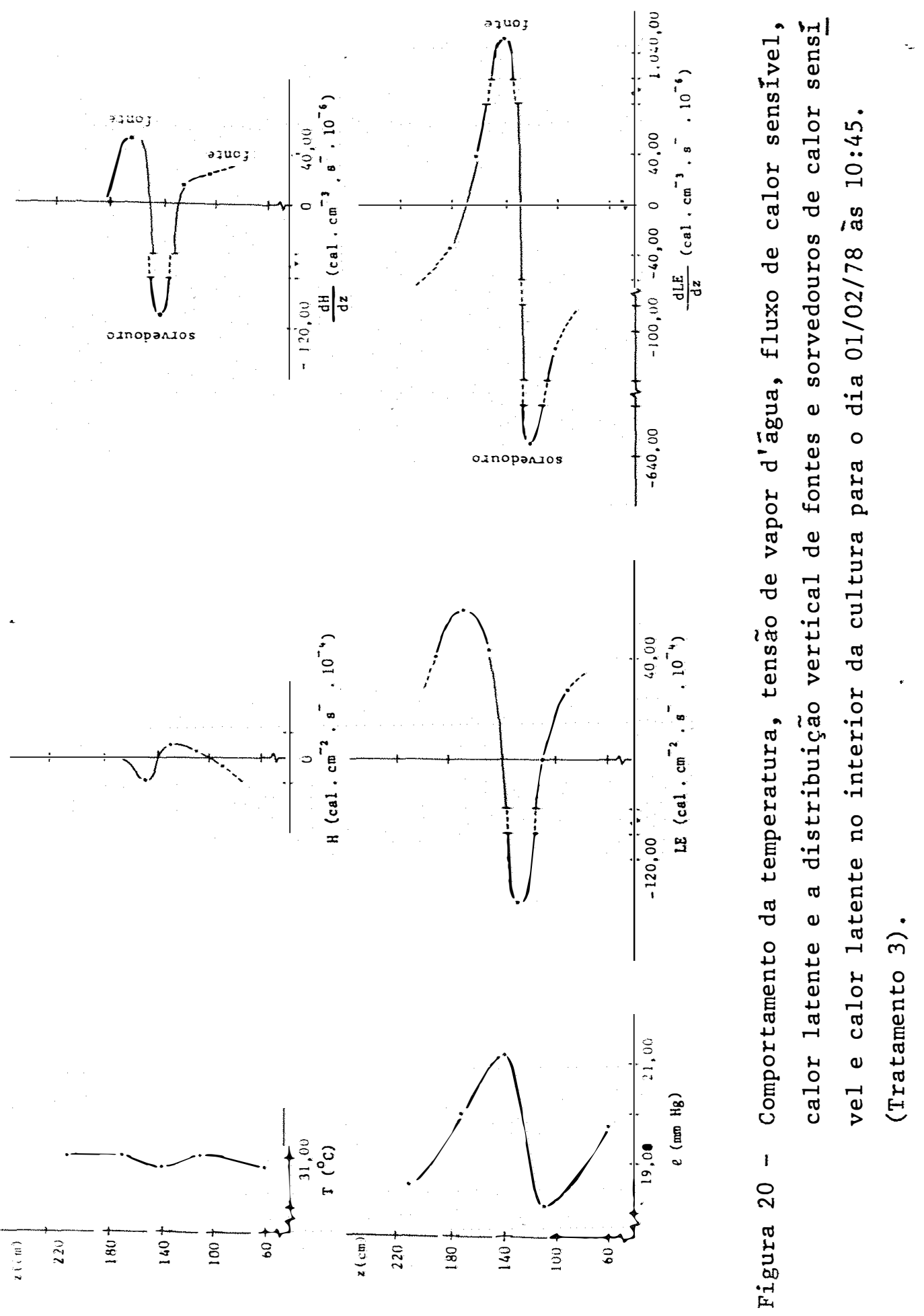


6. DISCUSSÃO DOS RESULTADOS

6.1. Perfis de temperatura e tensão de vapor d'água no interior da cultura

6.1.1. Perfis de temperatura

A anālise do comportamento da temperatura do ar no interior da cultura para o tratamento 1 (Figura 2(a) Tabela 3) mostra que nas primeiras horas do dia, ou seja, até o horário de 7:15, os perfis de temperatura são aproximadamen te isotérmicos nas regiões abaixo do nível médio da cultura, apresentando variações mais significativas a partir deste ní vel. Inicialmente a temperatura tende a decrescer com a altura manifestando-se com o decorrer do tempo uma tendência inversa.

o contínuo aumento da temperatura com a altura é observado até o horārio de 9:15, verificando-se às 9:45 a presença de gradientes positivos e negativos ao longo do per- 
fil. As inversões do sinal do gradiente ocorrem nas proximidades do nível médio da cultura, em $z=110 \mathrm{~cm}(0,41 \mathrm{~h})$ e $z=140 \mathrm{~cm}$ $(0,52 h)$.

Com o prosseguimento do dia predominam as in versões nestes níveis. Em alguns horários, entretanto, estas ocorrem em $z=110 \mathrm{~cm}$ e $z=170 \mathrm{~cm}(0,63)$, como no horário de $11: 15$, ou $z=140 \mathrm{~cm}$ e $z=170 \mathrm{~cm}(11: 45$ e 15:15). Verifica-se também um contínuo aumento da temperatura com a altura em cer tos horários do período médio do dia (10:15, 12:15, 12:45, $13: 15,14: 45)$. Aproximando-se o final do dia (17:15 e 17:45) o comportamento da temperatura tende a ser semelhante ao ob servado no início do dia.

Neste tratamento, as temperaturas máximas ge ralmente são atingidas próximo ao topo da cultura $(z=210 \mathrm{~cm}$ ou $0,78 \mathrm{~h})$ e as mínimas próximo a superfície do solo $(z=60 \mathrm{~cm}$ ou $0,22 \mathrm{~h})$. As temperaturas mais elevadas e a maior diferença entre as temperaturas mínima e máxima ocorridas, num dado perfil, são verificadas em horários próximos ao meio dia.

No período inicial do dia, nota-se para o tratamento 2 (Figura 3(a) - Tabela 7) um comportamento semelhante ao observado no tratamento 1. Assim, os perfis apresentam um caráter isotérmico nas regiões inferiores ao nível médio da cultura e gradientes mais significativos a partir deste nível. Inicialmente a temperatura tende a diminuir com a altura, manifestando-se com o decorrer do tempo a tendência a um contí- 
nuo aumento, permanecendo este comportamento até o horário de $8: 45$.

o perfil obtido para as 9:15 jà apresenta gradientes positivos e negativos, verificando-se a inversão do sinal próximo ao nível $z=170 \mathrm{~cm}$, que corresponde ao ponto de temperatura máxima. Um comportamento semelhante é observado até as 10:15 e nos horários de 11:45 e 13:15.

A medida que o dia prossegue predominam as inversões próximas aos níveis $z=110 \mathrm{~cm}$ e $z=140 \mathrm{~cm} \mathrm{ou} z=170 \mathrm{~cm}$, correspondendo respectivamente aos pontos de temperatura míni ma e máxima. Os horários de $13: 45$ e 14:45 apresentam um contínuo aumento da temperatura, com menores variações até o nível $z=110 \mathrm{~cm}$. No período final do dia (16:15 às 17:45) mani festa-se a tendência a um contínuo aumento da temperatura para $z>110 \mathrm{~cm}$, observando-se até este nível um decréscimo de temperatura.

Nota-se que neste tratamento as temperaturas má ximas e mínimas movem-se ao longo do dia, ocorrendo, especia 1 mente no período médio do dia, próximo ao nível médio da cultura e nas regiões mais próximas à superfície do solo ou ao to po da cultura, em horários próximos ao início ou fim do dia. Os valores mais elevados e a variação máxima é observada próximo ao meio dia. Verifica-se neste tratamento maiores variações de temperatura que no tratamento 1 .

$$
\text { No tratamento } 3 \text { (Figura } 4(a)-\text { Tabela 11) os }
$$


perfis de temperatura obtidos para as primeiras horas do dia, ou seja até o horário de 7:15, são aproximadamente isotérmi cos, apresentando as variações mais significativas a partir de $z=170 \mathrm{~cm}$. Como nos tratamentos anteriores, inicialmente há a tendência a decréscimo de temperatura, manifestando - se com o decorrer do tempo a tendência a um contínuo aumento de temperatura. Entretanto, neste tratamento, a duração do perí odo caracterizado pelo decréscimo de temperatura é maior que nos outros tratamentos. Este fato pode ser atribuído a maior penetração da radiação solar no plantio orientado, havendo por tanto, um aquecimento mais rápido da superfície do solo, além de movimentos convectivos mais vigorosos, apressando assim, a inversão do comportamento da temperatura. 0 mesmo não se verifica no tratamento 3 devido o plantio ao acaso.

A presença de gradientes de temperatura positi vos e negativos num dado perfil é observada mais cedo que nos demais tratamentos $(8: 15)$. Neste horário as inversões do sinal ocorrem nas proximidades do nível z=140cm, que corres ponde a temperatura máxima, e $z=170 \mathrm{~cm}$. Este comportamento repete-se no horário de 8:45, embora a temperatura máxima não ocorra próximo ao nível médio da cultura.

Com o prosseguimento do dia observa-se que pre dominam, até ofinal do dia, as inversões próximo aos níveis $z=110 \mathrm{~cm}$ e $z=140 \mathrm{~cm}$, ocorrendo, especialmente nos horários mais próximos ao meio dia $(11: 15$ às 12:15), a temperatura mäxi 
ma em $z=140 \mathrm{~cm}$. Nos horärios de 12:45 e 13:15 verifica - se inversões em níveis diferentes.

As temperaturas máximas e mínimas ora ocorrem nas extremidades $(z=60 \mathrm{~cm}$ e $z=210 \mathrm{~cm})$, ora nas proximidades do nível médio da cultura, sendo predominante o primeiro caso, especialmente nos horārios próximos ao início ou fim do dia. Verifica-se no período médio do dia as temperatura mais eleva das e a variação máxima.

Ao comparar os resultados obtidos nos três tra tamentos observa-se que a temperatura comporta-se no tratame to 2 de maneira inversa à verificada nos tratamentos 1 e 3 . Enquanto no tratamento 2 há um acrēscimo de temperatura na ca mada 110-140cm, há um decréscimo nos demais tratamentos. Este fato evidencia a influência da técnica de plantio utilizada na determinação do regime de temperatura no interior da cul tura.

Nos tratamentos 1 e 2 as formas dos perfis variam mais frequentemente, a passo que no tratamento 3 um mes mo comportamento é observado por um intervalo de tempo maior. Esta observação sugere que o plantio orientado possibilitou o aparecimento de um movimento turbulento mais intenso, associa do à maior circulação do ar entre as plantas, tornando assim os tratamentos 1 e 2 mais sensíveis às variações de temperatú ra ao longo do período de observação. Os perfis atípicos verificados ao mudar um dado comportamento, nos diferentes tra- 
tamentos, possivelmente representam um período de transição.

6.1.2. Perfis de tensão de vapor d'água

A anālise do comportamento da tensão de vapor d'água obtida para o tratamento 1 (Figura 2(b) - Tabela 3) mos tra, no período inicial do dia, ou seja até às 6:45, a tendên cia a um decréscimo até aproximadamente o nível médio da cultura, tendendo a aumentar a partir daí, embora apresente gradientes menos significativos. Os horārios de 7:45 e 8:15 apresentam inversões do sinal do gradiente próximo a $z=140 \mathrm{~cm}$ (ponto de tensão de vapor mínima às 7:45) e z=170 cm. Com o decorrer do dia a tensão de vapor mínima é observada no nível $z=110 \mathrm{~cm}$, havendo também inversões próximo a $z=140 \mathrm{~cm}$ e $z=$ $170 \mathrm{~cm} \quad(8: 45$ e $9: 15)$.

No período de $9: 45$ às $13: 45$ as inversões ocorrem predominantemente nas proximidades do nível médio da cultura, $z=110 \mathrm{~cm}$ e $z=140 \mathrm{~cm}$. Observa-se a partir do horário de 14:15 que as inversões geralmente ocorrem nos níveis $z=110$ $\mathrm{cm}$ e $z=170 \mathrm{~cm}$. A medida que se aproxima o final do dia mani festa-se a tendência a um contínuo decréscimo da tensão de va por d'água com a altura (17:45). No início desta fase verifi ca-se nos níveis de inversão a tensão de vapor mínima $(z=110 \mathrm{~cm})$ e máxima $(z=170 \mathrm{~cm})$ e com o decorrer do tempo estes valores vão ocorrendo nas regiões mais próximas à superfície do solo $(z=60 \mathrm{~cm})$ ou ao topo da cultura $(z=210 \mathrm{~cm})$, respectivamente. 
A maior diferença entre os valores mínimos e máximos ocorri dos ao longo do perfil é observada às 16:15.

Como o tratamento 1 , o tratamento 2 (Figura 3 (b) - Tabela 7) apresenta, já no início do dia, gradientes de tensão de vapor positivos e negativos ao longo dos perfis. Nos horários de 6:15 e 6:45 verifica-se a tensão de vapor d'á gua máxima próximo ao nível z = $110 \mathrm{~cm}$, observando-se um de créscimo na região $110<z<170$ e um acréscimo acima de $z=$ $170 \mathrm{~cm}$, sendo menores as variações nesta região. Os perfis re ferentes aos horários de 7:15, 7:45 e 8:15 apresentam a inver são do sinal do gradiente nas proximidades de $z=170 \mathrm{~cm}$ e pequenas variações nas regiões inferiores ao nível médio da cul tura.

A medida que o dia prossegue passam a predominar, por todo período de observação, as inversões próximo aos níveis $z=110 \mathrm{~cm} \mathrm{e} z=170 \mathrm{~cm}$, correspondendo em geral às tensões de vapor d'água máxima e mínima, respectivamente. Obse va-se também inversões em outros níveis, como próximo a $z=110$ $\mathrm{cm} \mathrm{e} z=140 \mathrm{~cm}(8: 15), z=130 \mathrm{~cm} \mathrm{e} z=170 \mathrm{~cm}(11: 45), \quad z=110 \mathrm{~cm}$ (tensão de vapor mínima) e $z=140 \mathrm{~cm}$ (tensão de vapor máxima) para o horário de 12:45. A variação máxima e as maiores tensões de vapor d'água são verificadas no período médio do dia.

No tratamento 3 (Figura $4(\mathrm{~b})$ - Tabela 11) ob serva-se, nas primeiras horas do dia $(6: 15$ e 6:45), um decrés cimo de tensão de vapor d'água na camada da cultura estudada, 
apresentando variações mais significativas a medida que se aproxima do topo da cultura. A partir do horário de 7:15 come ça a se observar a presença de gradientes de tensão de vapor d'água positivos e negativos ao longo dos perfis. Neste horá rio verifica-se a inversão do sinal do gradiente nas proximidades de $z=170 \mathrm{~cm}$, ocorrendo aí a tensão de vapor máxima.

Os horários de 7:45 e 8:15 caracterizam-se por um decréscimo da tensão nas regiões próximas à superfície do solo $(z<110 \mathrm{~cm})$ e um acrēscimo nas proximidades do nível médio da cultura $(110<z<140 \mathrm{~cm})$, observando-se às 7:45 um de créscimo para $z>140 \mathrm{~cm}$ e um acréscimo às 8:15. Com o decorrer do dia predominam inicialmente as inversões próximas aos níveis $z=110 \mathrm{~cm}$ (tensão de vapor mínima), $z=140 \mathrm{~cm}$ e $z=170$ cm (8:45 às 9:45). No período médio do dia (10:15 às 13:45) as inversões ocorrem em $z=110 \mathrm{~cm} \mathrm{e} z=140 \mathrm{~cm}$, correspondendo aos pontos de tensão de vapor mínima e máxima, respectivamente. Após este período o comportamento da tensão de vapor pas sa a ser semelhante ao observado às 9:45, observando-se no fi nal do dia a tendência a um decréscimo em z>140cm (17:45). Tanto as tensões de vapor d'água mais elevadas como a varia ção māxima são verificadas no período médio do dia.

No tratamento 3 a tensão de vapor d'água com porta-se de maneira semelhante à observada no tratamento 1 , a presentando-se entretanto, mais uniforme e com maiores dife renças entre os valores extremos, ao longo do dia. Este comportamento é oposto ao verificado para o tratamento 2 , eviden 
ciando assim, a influência das modificações introduzidas na técnica de plantio no comportamento da tensão de vapor d'água. A maior uniformidade observada no tratamento 3 revela a pre sença de um movimento turbulento menos intenso, associado a menor circulação do ar entre as plantas devido o plantio ao a caso.

Em relação à temperatura, nos diferentes trata mentos, a tensão de vapor d'água mostra um comportamento opos to. Os pontos de mínimos correspondem a máximos, predominando portanto, um decréscimo de tensão de vapor associado a um acréscimo de temperatura. Os perfis de tensão de vapor são mais uniformes, sugerindo que o transporte de vapor d'água re quer movimentos convectivos mais vigorosos.

\subsection{Fluxos de calor sensível e calor latente.}

os fluxos de calor sensível e calor latente fo ram determinados a partir das equações (1) e (2). Os gradien tes de temperatura $(d T / d z)$ e de tensão de vapor d'água (de/dz) foram obtidos graficamente para a seguinte faixa da cultura: $90 \leqslant z \leqslant 190 \mathrm{~cm}$, a cada $20 \mathrm{~cm}$. Este procedimento é uma das dificuldades do método utilizado na determinação dos fluxos, principalmente ao localizar os pontos de inflexão do perfil. Entretanto, mesmo com estas 1 imitações obteve-se diferenças significativas nos fluxos determinados para os três tratamentos. 
Observa-se nas equações (1) e (2) que a inversão do sinal do gradiente de temperatura e tensão de vapor d'água implica em regiões de fluxos de sentidos opostos, indi cando portanto a presença de fontes e sorvedouros de calorsen sível e latente. No presente estudo, os fluxos no sentido da superfície do solo para o topo da cultura, ou seja os fluxos ascendentes, são considerados positivos, enquanto os fluxos descendentes säo considerados negativos.

\subsubsection{Fluxos de calor sensível}

A anālise dos fluxos de calor sensível para o tratamento 1 (Figura 6 - Tabela 14) mostra que no início do dia (6:15 e 6:45) predominam os fluxos positivos na faixa da cultura estudada, passando a predominar os fluxos negativos com o passar do tempo. Isto é observado até o horário de 9:15 e a partir daí a medida que o dia prossegue observa-se que nas regiões médias da cultura predominam fluxos positivos, e fluxos negativos nas regiões mais próximas do topo da cultura ou da superfície do solo. Em alguns horários do período médio do dia os fluxos são descendentes $(10: 15,12: 15,12: 45$ e 14:45). Aproximando-se o final do dia os fluxos vão tornando-se negativos (17:15 e 17:45). Os valores máximos absolutos são ob servados nos horários de $13: 45\left(-42,45 \cdot 10^{-4} \mathrm{cal} \cdot \mathrm{cm}^{-2} \cdot \mathrm{s}^{-}, z=150\right.$ $\mathrm{cm})$ e $16: 15\left(45,58 \cdot 10^{-4} \mathrm{cal} \cdot \mathrm{cm}^{-2} \cdot \mathrm{s}^{-}, \quad z=170 \mathrm{~cm}\right)$. 
cio do dia (6:15) observa-se fluxos positivos, passando a se observar fluxos negativos até o horário de 8:45. A medida que se aproxima do meio dia, tem-se inicialmente fluxos negativos apenas para $z<170 \mathrm{~cm}(9: 15$ às 10:15), passando estes a predo minar, posteriormente, nas proximidades do nível médio da cu tura e os fluxos positivos nas camadas acima e abaixo desta região.

A partir do horário de 14:45 começa a se manifestar a tendência a inversão deste comportamento, até observar o predomínio de fluxos descendentes, ao longo da região estudada, ao se aproximar do final do dia. Em geral os fluxos mais intensos ocorrem nas proximidades do nível médio da cultura $\left(-94,13 \cdot 10^{-4} \mathrm{ca} 1 \cdot \mathrm{cm}^{-2} \cdot \mathrm{s}^{-}, z^{-}=130 \mathrm{~cm}\right)$ e em horários mé dios do dia $(12: 15)$.

Nota-se para o tratamento 3 (Figura 8 - Tabela 16) nas primeiras horas do dia (6:15 e 6:45) fluxos positivos, especialmente nas camadas acima do nível médio da cultura, ob servando-se fluxos negativos no período seguinte (7:15 e 7:45). Com o prosseguimento do dia verifica-se que predominam nas re giões acima e abaixo da região mais próxima ao nível médio da cultura fluxos descendentes, e ascendentes nesta região, por todo período de observação.

Este comportamento é semelhante ao observado no tratamento 1 , observando-se que no tratamento 3 é mais uni forme, ao longo do dia. Os fluxos mais intensos também são 
verificados nas proximidades do nível médio da cultura e no período médio do dia $\left(53,97 \cdot 10^{-4} \cdot \mathrm{cal} \cdot \mathrm{cm}^{-2} \cdot \mathrm{s}^{-}, z=130 \mathrm{~cm}\right.$ às $14: 15)$.

Comparando os diferentes tratamentos, observase que as regiões de fluxos ascendentes, no tratamento 2 , a presentam fluxos descendentes nos tratamentos 1 e 3 , evidenci ando que as modificações introduzidas na técnica de plantio foram significativas para o processo de transporte de calor sensível. A maior uniformidade verificada no tratamento 3 ao longo do dia, revela a menor intensidade do movimento turbu lento neste tratamento, devido o plantio ao acaso, além da me nor penetração da radiação. Observa-se que as maiores trocas de calor ocorrem no tratamento 2, principalmente nas camadas médias e em horärios de maiores altitudes do sol. Este fató indica que estas camadas encontram-se mais aquecidas em relação as camadas inferiores e superiores, possivelmente devido à maior penetração da radiação solar e a intensidade do movimento turbulento nesta região.

6.2.2. F1uxos de calor latente

Verifica-se, ao analisar os dados de calor 1 atente no tratamento 1 (Figura 9 - Tabela 14), que nas primeiras horas do dia $(6: 15$ às $7: 15)$ apresentam os fluxos negativos nas proximidades do nível médio da cultura e acima deste níve1, observando-se nas regiões inferiores fluxos ascenden - 
tes. Com o prosseguimento do dia os fluxos negativos predomi nam apenas nas camadas mais próximas ao nível médio, e nas ou tras fluxos positivos.

Alguns horários apresentam fluxos descendentes nas proximidades do nível médio e para $z>170 \mathrm{~cm}$, e nas camadas $z<110 \mathrm{~cm}, 110<z<170$ fluxos positivos. Aproximando se do final do dia manifesta-se a tendência a fluxos positivos por toda região estudada (17:45), observando-se as maio res trocas de vapor d'água nas regiões próximas ao topo da cul tura. Em geral, verifica-se os fluxos mais intensos em pon tos médios $\left(-151,91 \cdot 10^{-4} \mathrm{ca} 1 \cdot \mathrm{cm}^{-2} \cdot \mathrm{s}^{-}, z=130 \mathrm{~cm}, 9: 45\right)$.

No tratamento 2 (Figura 10 - Tabe1a 15), jā no período inicial do dia, manifesta-se a tendência à ocorrer flu xos de calor latente ascendentes na região média da cultura, e fluxos de sentido oposto nas camadas superiores e inferio res, predominando este comportamento ao longo do dia. 0 fluxo mais intenso foi observado no horário de 17:15 (208,30. $\left.10^{-4} \mathrm{cal} \cdot \mathrm{cm}^{-2} \cdot \mathrm{s}^{-1}\right)$ em $\mathrm{z}=150 \mathrm{~cm}$.

Para o tratamento 3 (Figura 11 - Tabe1a 16) os fluxos de calor latente são dirigidos para cima no início do dia (6:15 e 6:45), ocorrendo os valores máximos próximos ao topo da cultura. Ao longo do dia, observa-se nos horários mé dios da manhã e da tarde, fluxos positivos para $90 \leqslant z<110 \mathrm{~cm}$ e $140<z<170 \mathrm{~cm}$, e negativos nas outras regiões. Este comportamento também é observado em alguns horários no tratamen- 
to 1 , sem ser algo uniforme como no tratamento 3 .

Nos horários médios do dia predominam os flu xos positivos para $z<110$ e $z>140 \mathrm{~cm}$, e fluxos negativos pró ximos ao nível médio da cultura. Os valores máximos absolu tos ocorrem próximo ao nível médio da cultura $\left(445,70 \cdot 10^{-4}\right.$. cal $\left.\mathrm{cm}^{-2} \cdot \mathrm{s}^{-}\right)$, sendo em geral significativamente superiores aos observados nos demais tratamentos. Observa-se também, uma mai or uniformidade no comportamento dos fluxos de calor latente, neste tratamento, em relação aos demais tratamentos.

Ao comparar os resultados obtidos para o calor latente nos diferentes tratamentos nota-se claramente que as modificações introduzidas na técnica de plantio influenciaram o processo de transporte de vapor d'água, visto que os tratamentos 1 e 3 apresentam comportamentos semelhantes e opostos ao observado para o tratamento 2. A maior uniformidade obser vada no tratamento 3 e os fluxos mais intensos evidenciam novamente a presença de um movimento turbulento menos vigoroso.

Em relação aos fluxos de calor sensível, obser va-se que em geral, os fluxos de calor latente são significativamente mais intensos. Assim sendo, pode-se dizer que, durante o período diurno maior parte da energia disponívelé gas ta no processo de evaporação d'àgua. Nota-se nos diferentes tratamentos que o comportamento do calor latente tende a ser oposto ao verificado para o calor sensível. Apresenta, além disso, maior uniformidade ao longo do dia, portanto as fontes 
e sorvedouros de vapor d'água encontram-se mais uniformemente distribuidas neste período.

6.2.3. Variação diária dos fluxos de calor sensível e calor 1 atente

Ao analisar a figura 12, verifica-se que predo minam no tratamento 1 fluxos de calor sensível descendentes em quase todas as camadas, indicando que em geral as camadas superiores estão mais aquecidas e liberam calor para as camadas abaixo delas. As camadas médias da cultura $\quad z=110,130$ e 150 cm) apresentam fluxos ascendentes em horários próximos ao meio dia. As camadas $z=170$ e $190 \mathrm{~cm}$ apresentam maiores fluxos em horários mais próximos ao final do dia (15:45 e 16:15).

A medida que se aproxima da superfície do solo os fluxos tornam-se menos intensos, indicando que as camadas mais profundas estão sujeitas à pequenas variações ao longo do dia. Este fato mostra que neste tratamento, embora seja rientado, é menor a penetração da radiação solar devido a mai or densidade de plantas.

No tratamento 2 (Figura 13) as camadas médias, $z=110 \mathrm{~cm} \mathrm{e} z=130 \mathrm{~cm}$ apresentam predominantemente fluxos des cendentes ao longo do dia, observando-se os fluxos mais inten sos em horários médios, em $z=150 \mathrm{~cm}$. Nota-se na camada $z=$ $130 \mathrm{~cm}$ uma certa simetria, verificando-se assim, fluxos de mes 
ma grandeza no período inicial e final do dia. Observa-se pa ra as camadas $z=190,170,150$ e $90 \mathrm{~cm}$ fluxos ascendentes no período médio do dia.

Não se observa, como no tratamento 1 , a tenden cia a fluxos quantitativamente menores a medida que se aproxi ma do solo, observando-se em geral trocas aproximadamente i guais nas camadas $z=190,170,110$ e $90 \mathrm{~cm}$. Este fato indica que estas camadas estão sujeitas a variações de temperatura se melhantes, devido tanto a maior penetração da radiação solar e a sua uniformidade, como a maior circulação do ar entre as plantas, provocada pelo plantio orientado e a menor densidade de plantas.

A anälise da figura 14 mostra que o comporta mento do calor sensível nas diferentes camadas ao longo do di a, no tratamento 3 , tende a ser semelhante ao obtido para o tratamento 1. Verifica-se também neste tratamento, menores trocas de calor ao longo do dia nas camadas inferiores, evi denciando assim menor penetração de radiação solar e a menor circulação do ar decorrentes do plantio ao acaso.

No tratamento 1 predomina, ao longo do dia, flu $\underline{u}$ xos de calor 1 atente ascendentes nas camadas $z=90,170$ e 190 cm, havendo portanto perda de água para o meio ambiente nes tas camadas (Figura 15). A camada $z=110 \mathrm{~cm}$ na maior parte do dia não apresenta transporte de vapor d'água, portanto, não sofre variações de umidade ao longo do dia. Na camada $z=130$ 
cm predominam os fluxos descendentes ao longo do dia, indican do que esta camada recebe vapor d'água, verificando-se nesta camada as maiores trocas. Na camada $z=150 \mathrm{~cm}$ os fluxos passam a ser ascendentes nos horārios médios do dia, assim há evaporação de vapor d'água nestes horários. Observa-se na camada mais próxima à superfície da cultura $(z=90 \mathrm{~cm})$ fluxos menores em relação às camadas superiores.

A figura 16 mostra que no tratamento 2 as cama das $z=110 \mathrm{~cm}, 170 \mathrm{~cm}$ especialmente na faixa média do dia apre sentam fluxos nulos, não havendo portanto evaporação ou con densação nestas camadas. Nas camadas médias $z=130,150 \mathrm{~cm}$ predominam os fluxos ascendentes, indicando que na maior parte do dia estas camadas perdem ägua. Nas camadas $z=90$ e 190 cm verifica-se o predomínio de fluxos descendentes ao longo do dia, havendo portanto liberação de vapor d'água.

o calor latente nas diferentes camadas ao lon go do dia no tratamento 3 (Figura 17), comporta-se de maneira análoga à observada para o tratamento 1 , como também foi cons tatado na anālise da variação diária de calor sensível. En tretanto, no tratamento 3 , os fluxos de calor 1 atente são quantitativamente maiores, especialmente nas camadas médias e horários médios do dia. Em relação ao tratamento 2, observa-se um comportamento oposto ao observado para os tratamentos 1 e 3 , apenas nas camadas $z=90,130$ e $190 \mathrm{~cm}$.

Ao comparar os resultados obtidos, constata-se 
mais uma vez, a tendencia a um comportamento oposto do calor latente em relação ao calor sensível. Assim sendo, nota- se que o processo de liberação ou absorção de calor sensível de uma camada está associado, respectivamente, ao processo de evaporação ou condensação de vapor d'água.

6.3. Distribuição vertical e as intensidades das fontes e sorvedouros de calor sensível e calor latente.

Utilizando-se dos dados de temperatura e ten são de vapor d'água, referentes ao horärio de 10:45 do dia 01/ $02 / 78$, obteve-se através das equações (3) e (4), a intensidade das fontes ou sorvedouros de calor sensível e calor latente existentes nos pontos $z=100,120,140,160$ e $130 \mathrm{~cm}$. A re presentação gräfica destes valores mostra como as fontes e sor vedouros distribuem-se ao longo desta camada.

Ao apresentar nas figuras 18,19 e 20 os per fis de temperatura e tensão de vapor d'água juntamente com os fluxos de calor sensível e calor latente, pode-se observar cla ramente as diferenças existentes no comportamento destes elementos, tanto num dado tratamento como nos diferentes trata mentos, e também como influenciam a distribuição vertical das fontes e sorvedouros no interior da cultura.

A tabela 17 mostra que, na maioria das vezes a intensidade das fontes e sorvedouros de calor latente é signi 
ficativamente maior que a obtida para as fontes e sorvedouros de calor sensível, evidenciando assim o calor latente como mai or consumidor da energia disponível durante o período diurno. Observa-se, tanto para o calor latente como para o calor sensível, que as fontes ou sorvedouros situados nas proximidades do nível médio da cultura são mais vigorosas, indicando que nestas camadas há maior consumo ou maior liberação de energia.

A anālise das figuras 18,19 e 20 revela a semelhança na distribuição das fontes e sorvedouros de calor sen sível nos tratamentos 1 e 3 . Nestes tratamentos as regiões a baixo do nível médio da cultura e acima de $0,55 \mathrm{~h}$, aproximadamente, atuam como fontes de calor e a camada média, sorvedouro de calor. Assim sendo, pode-se dizer que a camada média rece be calor ao passo que as outras regiões fornecem calor. No tratamento 2, observa-se a tendência a uma distribuição oposta, verificando-se sorvedouros de calor sensível até próximo ao nível médio da cultura e a partir daí fontes de calor sensível.

Em relação à distribuição das fontes e sorve douros de calor latente observa-se também uma tendência oposta a comparar o tratamento 2 com os tratamentos 1 e 3 . Nestes tratamentos a região abaixo do nível médio da cultura at u a como sorvedouro de vapor d'água, enquanto que no tratamento 2 funciona como fonte de vapor d'ägua. Acima deste nível médio tem-se fontes de vapor d'água nos tratamentos 1 e 3 , opon 
90

do-se a sorvedouros do tratamento 2. Diante dessas observa ções pode-se dizer que nos tratamentos 1 e 3 , as camadas supe riores ao nível médio da cultura perdem água, ao passo que nas camadas inferiores hà um consumo de āgua, verificando-se o contrário no tratamento 2 .

Ao comparar as distribuições de fontes e sorve douros de calor e vapor d'água obtidas num mesmo tratamento, observa-se em geral que as regiões fontes (sorvedouras) de ca lor sensível correspondem a sorvedouros (fontes) de vapor d'ä gua, evidenciando, mais uma vez que a perda de água em uma ca mada está associada à absorção de calor sensível. 
7. CONCLUSÕES

A anālise dos resultados obtidos permite con cluir que:

1) No tratamento 3, com plantio ao acaso, as fontes e sorve douros de calor sensível manifestaram-se mais cedo ( $8: 15)$, que nos tratamentos $1(9: 45)$ e $2(9: 15)$, com plantio orien tado. Em relação às fontes e sorvedouros de calor latente verificou-se um comportamento oposto.

2) As fontes e sorvedouros de calor latente manifestaram - se mais cedo que as de calor sensível, nos três tratamentos.

3) As fontes e sorvedouros de calor latente mostraram-se mais uniformemente distribuidas ao longo do dia que as de calor sensíve 1 .

4) Os tratamentos 1 e 3 apresentaram comportamentos seme1hantes tanto para temperatura como para tensão de vapor d'á - 
gua e consequentemente para os demais elementos analisados, observando-se, em geral, um comportamento mais uniforme e com maiores variações no tratamento 3 .

5) Constatou-se que acréscimos de temperatura ou tensão de va por d'água no tratamento 2 correspondem a decréscimos destes elementos nos tratamentos 1 e 3 , além disso nas regi ões caracterizadas por fluxos ascendentes observou-se fluxos descendentes e vice-versa e consequentemente uma dis tribuição de fontes e sorvedouros de calor sensível ou vapor d'água inversa.

6) Observou-se, especialmente no tratamento 2, que uma região fonte de calor sensível é sorvedouro de calor latente e ví ce-versa.

7) Os fluxos de calor latente e calor sensível mais intensos, nos três tratamentos, ocorreram nas proximidades do nível médio da cultura e no período médio do dia. Sendo o fluxo de calor sensivel mais intenso verificado no tratamento 2 $\left(H(130)=-94,13 \cdot 10^{-4} \mathrm{cal} / \mathrm{cm}^{2} . \mathrm{s}\right.$ às $\left.12: 15\right)$ e o de fluxo de calor latente no tratamento $3\left(\operatorname{LE}(130)=445,70.10^{-4} \mathrm{cal} /\right.$ $\mathrm{cm}^{2} \cdot \mathrm{s}$ às $\left.12: 15\right)$.

8) Os fluxos de calor latente são quantitativamente maiores que os fluxos de calor sensível, revelando que uma parcela maior da energia disponível é utilizada no processo de eva poração d'água, durante o período diurno nos três tratamentos. 
8. SUMMARY

In this paper a quantitative analysis of sensible and latent fluxes within a maize (Zea mays, L.) crop, variety Cargil 111, was made. The influence of changes in the sowing technique on canopy microclimate was observed by the study of three different treatments.

From the usual flux-gradient equation sensible and latent fluxes and sources-sinks strengths were determined. It was adopted that the diffusivity decays exponentialy with depth down through the canopy.

Treatment 2 (oriented sowing and lower plant density) showed a vertical distribuition of the sources and sinks of sensible and latent heat contrary to that observed for treatment 1 (oriented sowing) and 3 (traditional sowing). The latent heat sources and sinks were stronger than sensible heat sources and sinks for all treatments. The more intense 
fluxes were observed near the middle of the canopy and in the midday. The maximum sensible and latent fluxes were observed for treatments 2 and 3 , respectively. 
9. LITERATURA CITADA

BAINES, G.B.K., 1972. Turbulence in a wheat crop. Agricultural Meteorology. 10:93-105.

BILL, R.G. Jr., L.H. ALLEN Jr., T. AUDUNSON, B. GEBHART e E. LEMON, 1976. Turbulent transport within and above a maize canopy. Boundary-Layer Meteorology. 10:199-220.

BROWN, K.W. e W. COVEY, 1966. The energy-budget evaluation processes within a cornfield. Agricultural Meteorology. 3: $: 73-96$.

BYRNE, G.F., ROSE, C.W. On the determination of vertical fluxes in field crop studies. Agricultural Meteorology. 10: $13-17$.

CIONCO, R.M., 1972. A wind-profile index for canopy flow. Boundary-Layer Meteorology. 3: 255-263. 
DENMEAD, O.T., 1976. Temperate cereals. Chapter 1 (pp.1-31). In: J.L. MONTEITH (Ed.), Vegetation and the Atmosphere, vo1. 2. Academic Press, London. 439 p.

DYER, A.J. e B.B. HICKS, 1970. Flux-gradient relationships in the constant flux fayer. Q.J.R. Met. Soc. 96:715-721. DYER, A.J., 1974. A review of flux-profile relationships . Boundary-Layer Meteorology. $\quad$ 7:363-372.

FRoTA, P.C.E., 1978. Estudo do comportamento do calor sensível e latente no interior de uma cultura de milho (Zea mays, L.). Piracicaba, ESALQ-USP, $65 \mathrm{p}$. (Tese de Mestrado).

GILLESPIE, T.J. e K.M. KING, 1971. Night-time sink strengths and the apparent diffusivities with a corn canopy. Agricultural Meteorology. 8: 59-67.

GRODZKI, L., 1978. Caracterização aerodinâmica da cultura de soja. Piracicaba, ESALQ-USP. 51 p. (Tese de Mestrado).

HICKS, B.B. e C.M. SHEIH, 1977. Some observations of eddy momentum fluxes within a maize canopy. Boundary-Layer Meteorology. 11:515-519.

HÖGSTRÖM, Ulf, 1974. A field study of the turbulent fluxes of heat, water vapour and momentum at a 'typical' agricultural siti. Quart. J. R. Met. Soc. 100:624-639. 
IDE, B.Y., 1978. Comportamento dos fluxos de momentum, calor sensível e vapor d'água, em. uma cultura de milho. Piracicaba, ESALQ-USP. 56 p. (Tese de Mestrado).

JOHNSON, C.E., P.V. BISCOE, J.A. CLARK e E. LITTLETON, 1976 . Turbulent transfer in a barley canopy. Agricultural. Meteorology. 16:17-35.

LEGG, B.J., 1975. Turbulent diffusion within a wheat canopy: I. Measurement using nitrous oxide. Quart. J.R. Met. Soc. $\underline{101: 597-610}$

LEGG, B.J. e I.F. LONG, 1975. Turbulent diffusion within a wheat canopy: II. Results and interpretation. Quart. J. R. Met. Soc. 101:611-628.

LEMON, E.R. e J.L. WRIGHT, 1969. Gaseous exchange in crop stands. Chapter 6 (pp. 117-137). In: R.C. DINAUER (Ed.) Physiological Aspects of Crop Yield, Am. Soc. of Agron., Crop. Sci. Soc. of America, Madison - Wisconsin. 396 p. MONTEITH, J.L., 1973. Principles of enviromental physics. New York, American Elsivier Publishing Company, Inc. 271 p. PRUITT, W.O., D.L. MORGAN e F.J. LOURENCE, 1973. Momentum and mass transfers in the surface boundary layer. Quart. J.R. Met. Soc. $99: 370-386$.

RAZANI, G., O. FREIRE e T. KINJO, 1966. Cartas de solos do Município de Piracicaba. Piracicaba, ESALQ-USP. 85 p. 
SCHUEPP, P.H. e K.O. WHITE, 1975. Transfer processes in vegetation by eletrochemical analog. Boundary-Layer Meteorology. $\quad$ 8: $335-358$.

SHAW, R.H., G.D. HARTOG, K.M. KING e G.W. THURTELL, 1974. Measurements of mean wind flow and three-dimensional turbulence intensity within a mature corn canopy. Agricultural Meteorology. 13:419-425.

SWINBANK, W.C., 1951. The measurement of vertical transfer of heat and wates vapor by eddies in lower atmosphere. J. Meteorol. 8: $135-145$.

THOM, A.S., 1971. Momentum absorption by vegetation. Quart. J.R. Met. Soc. $97: 414-428$.

THOM, A.S., 1972. Momentum, mass and heat exchange of vegetation. Quart. J.R. Met. Soc. 98:124-134.

UCHIJIMA, Z., 1976. Maize and Rice. In: J.L. MONTEITH (Ed.) Vegetation and atmosphere, vol. 2, Academic Press, London, pp. $33-64$.

WRIGHT, J.L. e K.W. BRONW, 1967. Comparasion of momentum and energy balance methods of computing vertical transfer within a crop. Agronomy Journal. 59:427-432. 